Nevada

DOE/NV-471-ReV. 2 UC-700

Environmental

Restoration

Project

RECEIVED

DEC 231997

OSTI

Corrective Action Decision

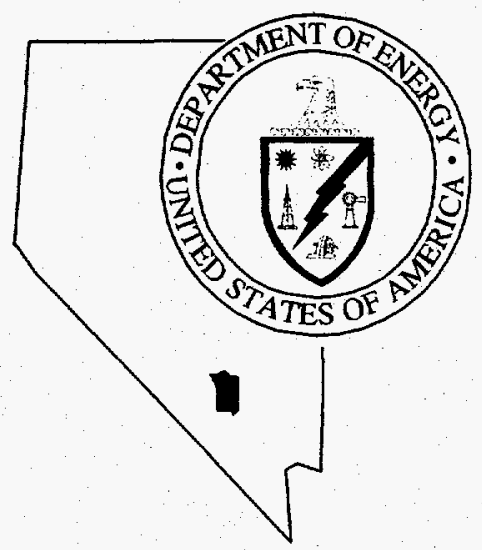

Document, Second Gas Station,

Tonopah Test Range, Nevada

[Corrective Action Unit No. 403]

Controlled Copy No.: Uncontrolled

Revision No.: 2

November 1997

Approved for public release; further distribution is authorized.

Environmental Restoration

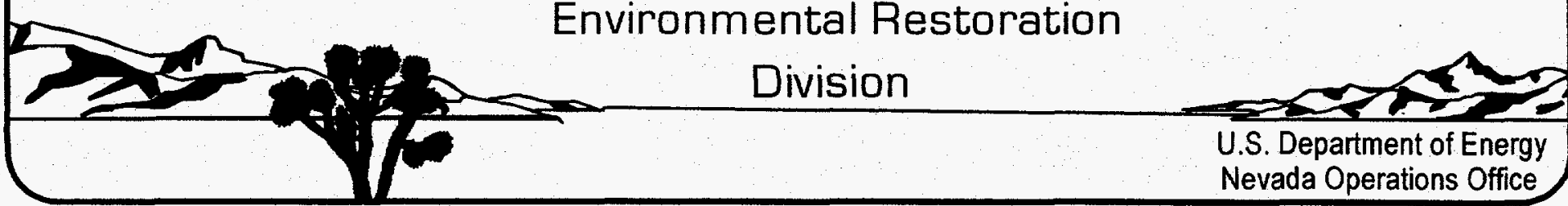




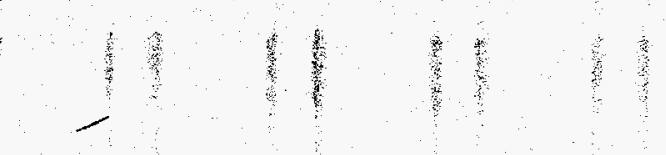

This report has been reproduced directly from the best available copy.

Available to DOE and DOE contractors from the Office of Scientific and Technical Information, P.O. Box 62, Oak Ridge, TN 37831; prices available from (423) 576-8401.

Available to the public from the National Technical Information Service, U.S. Department of Commerce, 5285 Port Royal Road, Springfield, VA 22161, telephone (703) 487-4650. 


\section{CORRECTIVE ACTION DECISION DOCUMENT, SECOND GAS STATION, TONOPAH TEST RANGE, NEVADA (CORRECTIVE ACTION UNIT NO. 403)}

DOE Nevada Operations Office

Las Vegas, Nevada

Controlled Copy No.: Uncontrolled

Revision No.: 2

DISTAREUTION OF THIS DOCUMENT IS UNAMAREP

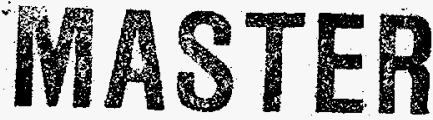

Approved for public release; further distribution is authorized. 


\section{DISCLAIMER}

This report was prepared as an account of work sponsored by an agency of the United States Government. Neither the United States Government nor any agency thereof, nor any of their employees, makes any warranty, express or implied, or assumes any legal liability or responsibility for the accuracy, completeness, or usefulness of any information, apparatus, product, or process disclosed, or represents that its use would not infringe privately owned rights. Reference herein to any specific commercial product, process, or service by trade name, trademark, manufacturer, or otherwise does not necessarily constitute or imply its endorsement, recommendation, or favoring by the United States Government or any agency thereof. The views and opinions of authors expressed herein do not necessarily state or reflect those of the United States Government or any agency thereof. 


\section{DISCLAIMER}

Portions of this document may be illegible electronic image products. Images are produced from the best available original document. 
CORRECTIVE ACTION DECISION DOCUMENT, SECOND GAS STATION, TONOPAH TEST RANGE, NEVADA (CORRECTIVE ACTION UNIT NO. 403)

Approved by:

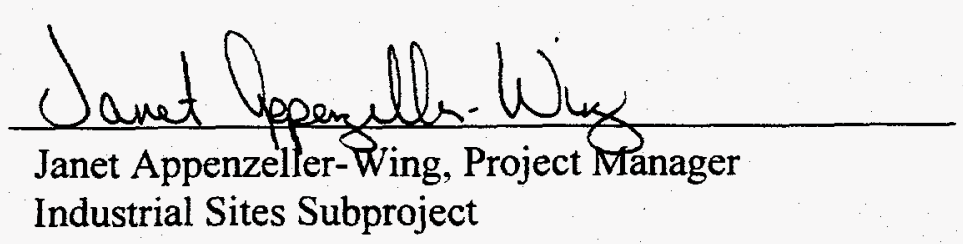

Date: $11 / 25 / 97$ Industrial Sites Subproject

Approved by:

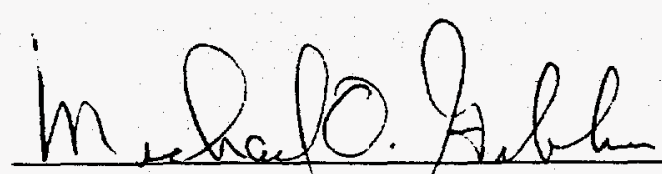

Michael O. Giblin, Acting Project Manager Nevada Environmental Restoration Project
Date:

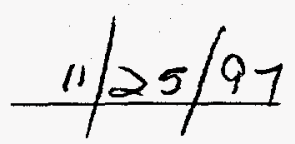




\section{Table of Contents}

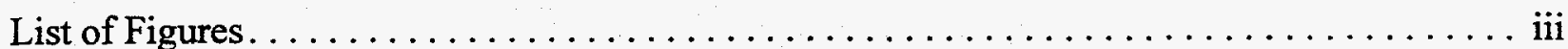

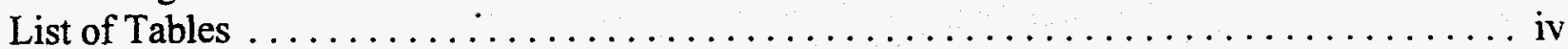

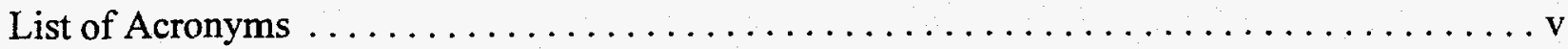

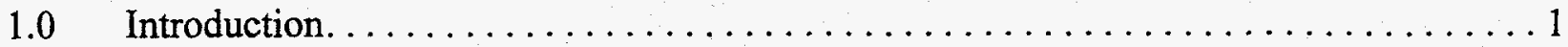

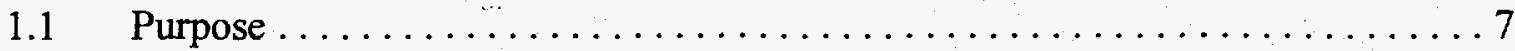

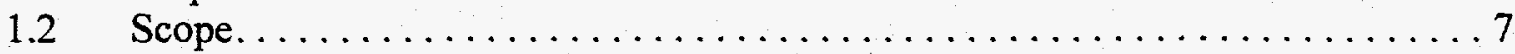

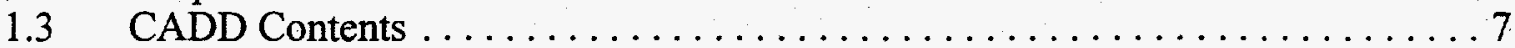

$2.0 \quad$ Corrective Action Investigation Summary $\ldots \ldots \ldots \ldots \ldots \ldots \ldots \ldots \ldots$

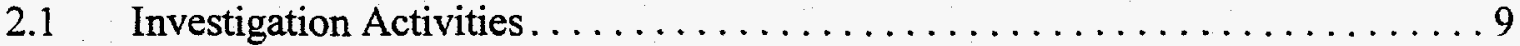

$2.2 \quad$ Results. . . . . . . . . . . . . . . . . . . . . . . . . . . . . 12

$2.3 \quad$ Need for Corrective Action. . . . . . . . . . . . . . . . . . . . . 12

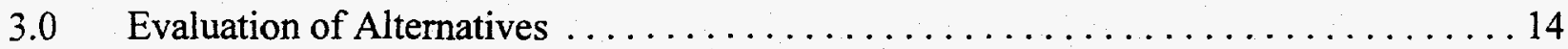

$3.1 \quad$ Corrective Action Objectives . ........................... 14

3.1.1 Contaminants of Concern ............................ 15

3.1.2 Potential Exposure Pathways . . . . . . . . . . . . . . . . . 15

3.1.3 Preliminary Cleanup Goal ........................ 15

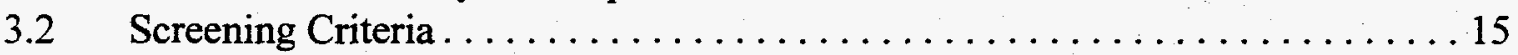

3.2.1 Overall Protection of Human Health and the Environment . . . . . . . 16

3.2.2 Attain Media Cleanup Standards ...................... 17

3.2.3 Control the Sources of the Release.................... 17

3.2.4 Comply with Applicable Standards for Management of Wastes . . . . 17

3.2.5 Short-Term Reliability and Effectiveness ................. 18

3.2.6 Reduction of Toxicity, Mobility, and/or Volume . . . . . . . . . . . . . 19

3.2.7 Long-Term Reliability and Effectiveness .................. 19

$3.2 .8 \quad$ Implementability. . . . . . . . . . . . . . . . . . . . . . . . . . 19

$3.2 .9 \quad$ Cost . . . . . . . . . . . . . . . . . . . . . . . . 20

3.3 Development of Corrective Action Alternatives ................. 20

3.3.1 Identification of Corrective Action Technologies ............ 20

3.3.2 Corrective Action Alternatives....................... 22

3.4 Evaluation and Comparison of Alternatives.................... 25

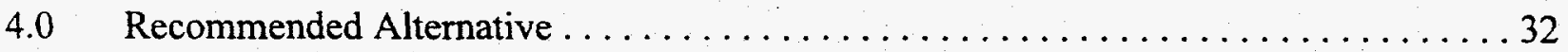

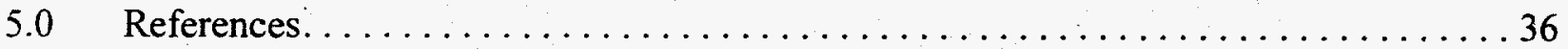




\section{Table of Contents (Continued)}

Appendix A - Second Gas Station Investigation Report Corrective Action Unit No. 403, Tonopah Test Range

A.1.0 Introduction. . . . . . . . . . . . . . . .

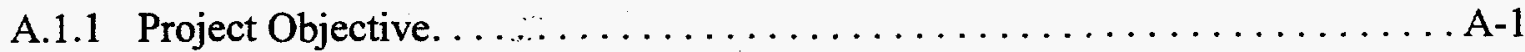

A.1.1.1 Report Content . . . . . . . . . . . . . . . . . . . A-6

A.1.1.2 Summary of Findings in Accordance with NAC 459.9973 . . . . . . A-7

A.2.0 Field Investigation and Sampling Activities. . . . . . . . . . . . . . . .

A.2.1 Site Description and Conditions . . . . . . . . . . . . . . . A-9

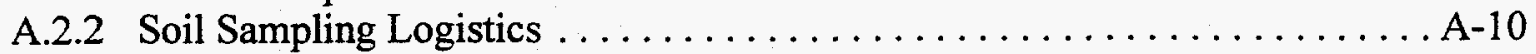

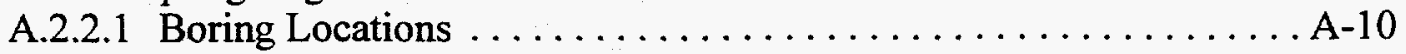

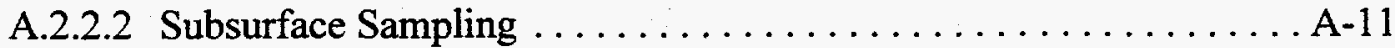

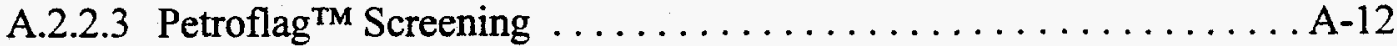

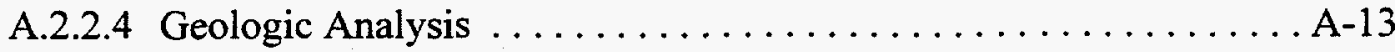

A.2.2.5 Drilling Characteristics. . . . . . . . . . . . . . . . A -13

A.2.2.6 Subsurface Stratigraphy . . . . . . . . . . . . . . . A-14

A.2.3 Management of Investigation-Derived Waste $\ldots \ldots \ldots \ldots \ldots \ldots \ldots \ldots$ A-14

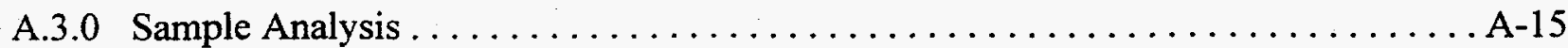

A.3.1 Data Quality Assessment . . . . . . . . . . . . . . . . . . A-19

A.3.2 Sample Results . . . . . . . . . . . . . . . . . . . . . .

A.3.3 Geotechnical and Bioassessment Samples . . . . . . . . . . . . A A-23

A.3.3.1 Bioassessment Results . . . . . . . . . . . . . . . A A-23

A.3.3.2 Geotechnical Analysis Results . . . . . . . . . . . . . . . A-24

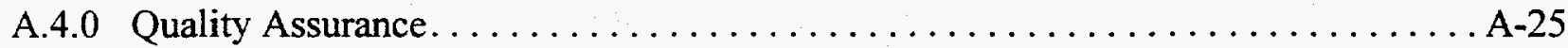

A.4.1 Quality Control Samples. .......................... A-25

A.4.1.1 Field Quality Control Samples................... A-25

A.4.1.2 Laboratory Quality Control Samples . . . . . . . . . . . . . . . A-27

A.4.2 Quality Assurance Objectives Measurements . . . . . . . . . . . . . A-27

A.4.2.1 Precision . . . . . . . . . . . . . . . . . . . . . A -27

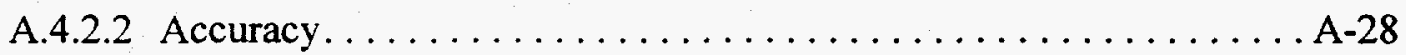

A.4.2.3 Representativeness . . . . . . . . . . . . . . . . . A-31

A.4.2.4 Completeness . . . . . . . . . . . . . . . . . . . . . A A-31

A.4.2.5 Comparability . . . . . . . . . . . . . . . . . A -31

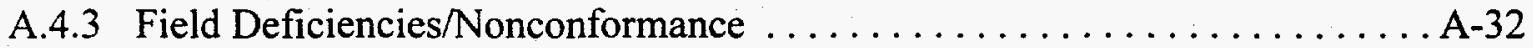

A.4.4 Laboratory Nonconformances . . . . . . . . . . . . . . . . . A-32

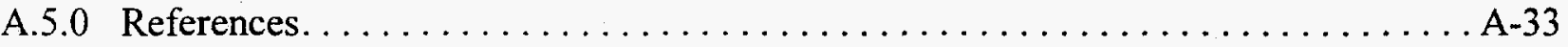

Appendix B - Cost Estimates 


\section{List of Figures}

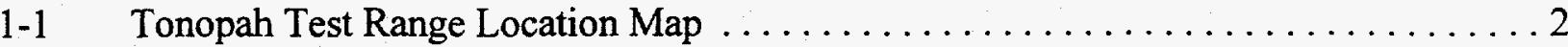

1-2 Location of the Second Gas Station, Area 3, Tonopah Test Range ............ 3

1-3 Original Site Map, Second Gas Station and Surrounding Facilities,

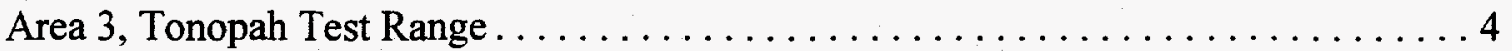

1-4 Current Site Map, Second Gas Station and Surrounding Facilities, Area 3, Tonopah Test Range .............................. 6

$2-1 \quad$ Original Second Gas Station Site Map $\ldots \ldots \ldots \ldots \ldots \ldots \ldots \ldots \ldots \ldots \ldots \ldots \ldots \ldots \ldots \ldots \ldots$

2-2 Current Second Gas Station Site Map $\ldots \ldots \ldots \ldots \ldots \ldots \ldots \ldots \ldots \ldots \ldots \ldots \ldots \ldots \ldots \ldots \ldots$

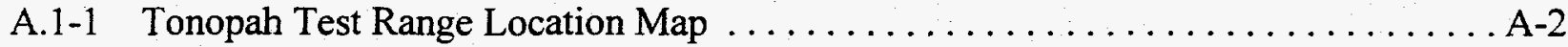

A.1-2 Location of the Second Gas Station, Area 3, Tonopah Test Range ........... A-3

A.1-3 Original Site Map, Second Gas Station and Surrounding Facilities, Area 3, Tonopah Test Range .............................. A-4

A.1-4 Current Site Map, Second Gas Station and Surrounding Facilities, Area 3, Tonopah Test Range ............................. A

A.3-1 Map of Soil Boring Locations, Second Gas Station, Tonopah Test Range. . . . . . A-18

A.3-2 Interpretations of TPH Distribution, Second Gas Station, Tonopah Test Range . . . A-22 


\section{List of Tables}

3-1 Detailed Evaluation of the Corrective Action Alternatives. . . . . . . . . . . 26

3-2 Detailed Comparison of the Corrective Action Alternatives. . . . . . . . . . . 30

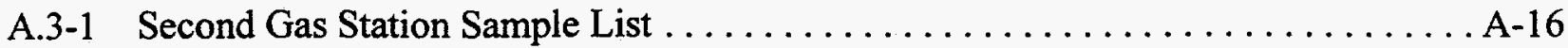

A.3-2 Chemical Analytical Methods Used for

Second Gas Station Investigation Samples

A.3-3 Tonopah Test Range Second Gas Station Results that Exceeded Detection Limits . A-21

A.4-1 Second Gas Station Field Quality Control Samples

Collected for Laboratory Analysis.

A.4-2 Laboratory Precision Measurements for

Second Gas Station Subsurface Soil Sampling Data.

A.4-3 Laboratory Accuracy Measurements for

Second Gas Station Subsurface Soil Sampling Data. .

B-1 IT Corporation Estimate Sheet 


\section{List of Acronyms and Abbreviations}

\begin{tabular}{|c|c|}
\hline bgs & Below ground level \\
\hline BTEX & Benzene, Toluene, Ethylbenzene, Xylene \\
\hline CADD & Corrective Action Decision Document(s) \\
\hline CAIP & Corrective Action Investigation Plan(s) \\
\hline CAS & Corrective Action Site(s) \\
\hline CAU & Corrective Action Unit(s) \\
\hline $\mathrm{cm}$ & Centimeter(s) \\
\hline $\mathrm{COC}$ & Contaminant(s) of concern \\
\hline DoD & U.S. Department of Defense \\
\hline DOE & U.S. Department of Energy \\
\hline DOT & U.S. Department of Transportation \\
\hline DQO & Data Quality Objective(s) \\
\hline EPA & U.S. Environmental Protection Agency \\
\hline $\mathrm{ft}$ & Foot (feet) \\
\hline FFACO & Federal Facility Agreement and Consent Order \\
\hline gal & Gallon(s) \\
\hline IDW & Investigation-derived waste \\
\hline in. & $\operatorname{Inch}(e s)$ \\
\hline IT & IT Corporation \\
\hline $\mathrm{km}$ & Kilometer(s) \\
\hline $\mathrm{L}$ & Liter(s) \\
\hline $\mathrm{m}$ & Meter(s) \\
\hline$m^{3}$ & Cubic meter(s) \\
\hline $\mathrm{mi}$ & Mile(s) \\
\hline $\mathrm{mg} / \mathrm{kg}$ & Milligram(s) per kilogram \\
\hline $\mathrm{mg} / \mathrm{L}$ & Milligram(s) per liter \\
\hline MS/MSD & Matrix spike/matrix spike duplicate \\
\hline NAC & Nevada Administrative Code \\
\hline NDEP & Nevada Division of Environmental Protection \\
\hline ppm & Part(s) per million \\
\hline ppb & Part(s) per billion \\
\hline PRG & Preliminary Remediation Goal(s) \\
\hline QA & Quality assurance \\
\hline
\end{tabular}




\section{List of Acronyms and Abbreviations (Continued)}

QAPP

QC

RCRA

RPD

SB

SO

TC

TID

TSD

TPH

TTR

UST

$\mathrm{yd}^{3}$
Quality Assurance Project Plan

Quality control

Resource Conservation and Recovery Act

Relative percent difference

Soil boring(s)

Step-out(s)

Toxicity characteristic

Tamper Indicating Device

Treatment, storage, and disposal

Total petroleum hydrocarbon(s)

Tonopah Test Range

Underground Storage Tank(s)

Cubic yard(s) 


\subsection{Introduction}

This Corrective Action Decision Document (CADD) for Second Gas Station (Corrective Action Unit [CAU] No. 403) has been developed for the U.S. Department of Energy's (DOE) Nevada Environmental Restoration Project to meet the requirements of the Federal Facility Agreement and Consent Order (FFACO) of 1996 as stated in Appendix VI, "Corrective Action Strategy" (FFACO, 1996).

The Second Gas Station Corrective Action Site (CAS) No. 03-02-004-0360 is the only CAS in CAU No. 403. The Second Gas Station CAS is located within Area 3 of the Tonopah Test Range (TTR), west of the Main Road at the location of former Underground Storage Tanks (USTs) and their associated fuel dispensary stations. The TTR is approximately 225 kilometers $(\mathrm{km})$ (140 miles [mi]) northwest of Las Vegas, Nevada, by air and approximately $56 \mathrm{~km}$ (35 mi) southeast of Tonopah, Nevada, by road. The TTR is bordered on the south, east, and west by the Nellis Air Force Range and on the north by sparsely populated public land administered by the Bureau of Land Management and the U.S. Forest Service (Figure 1-1 and Figure 1-2).

The Second Gas Station CAS was formerly known as the Underground Diesel Tank Site, Sandia Environmental Restoration Site Number 118. The gas station was in use from approximately 1965 to 1980. The USTs were originally thought to be located 11 meters (m) (36 feet [ft]) east of the Old Light Duty Shop, Building 0360, and consisted of one gasoline UST (southern tank) and one diesel UST (northern tank) (DOE/NV, 1996a). The two associated fuel dispensary stations were located northeast (diesel) and southeast (gasoline) of Building 0360 (CAU 423). Presently the site is used as a parking lot; Building 0360 is used for mechanical repairs of vehicles.

Since the issuance and implementation of the Second Gas Station Corrective Action Investigation Plan (CAIP), the initial subsurface investigation, and the issuance of Revision No. 1 of this CADD, new information was discovered that shows the USTs were configured differently than they were portrayed in the CAIP. Due to this new information, an additional subsurface boring was drilled to complete the subsurface investigation. Figure 1-3 depicts the tank configurations used in the original 


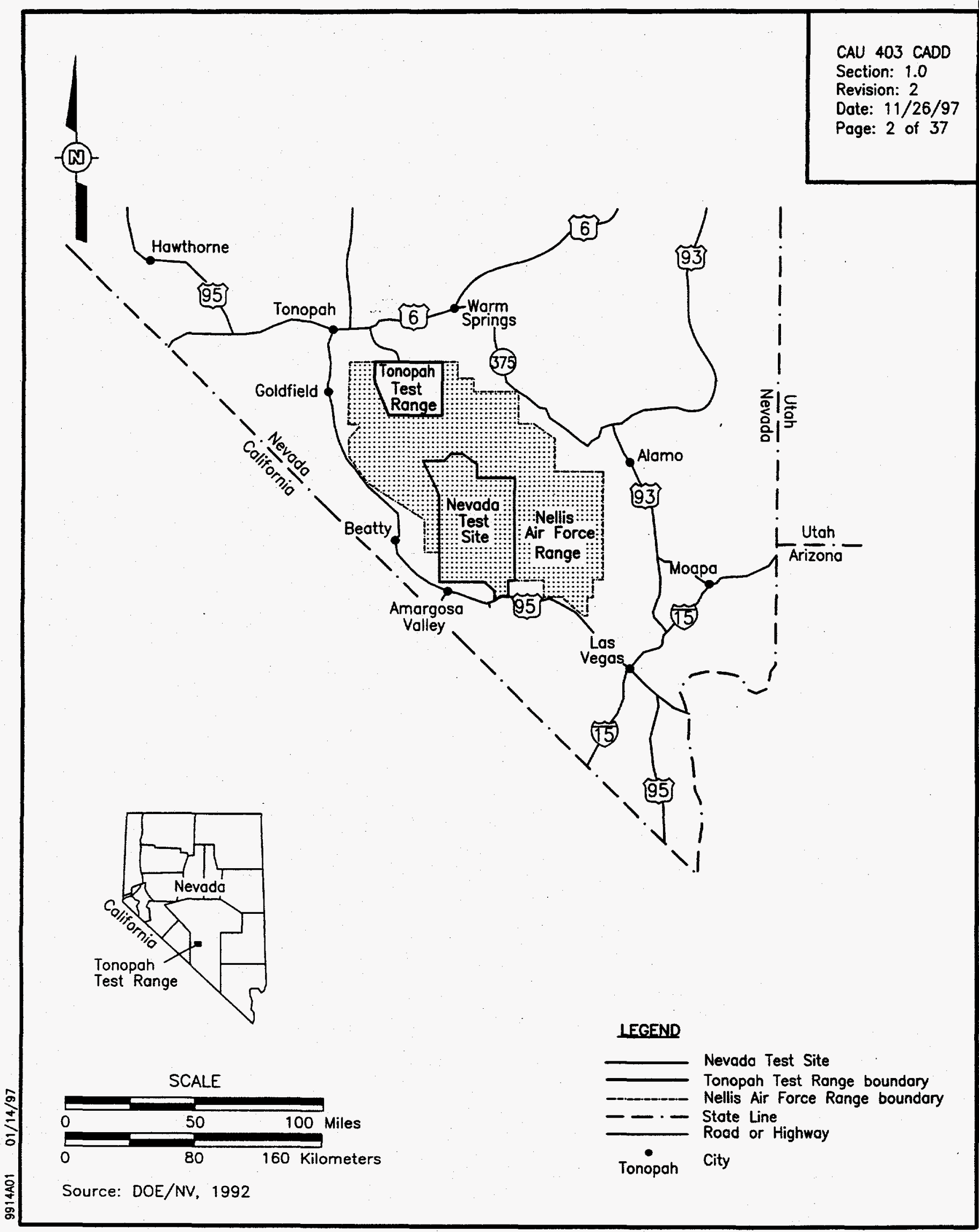

Figure 1-1

Tonopah Test Range Location Map 


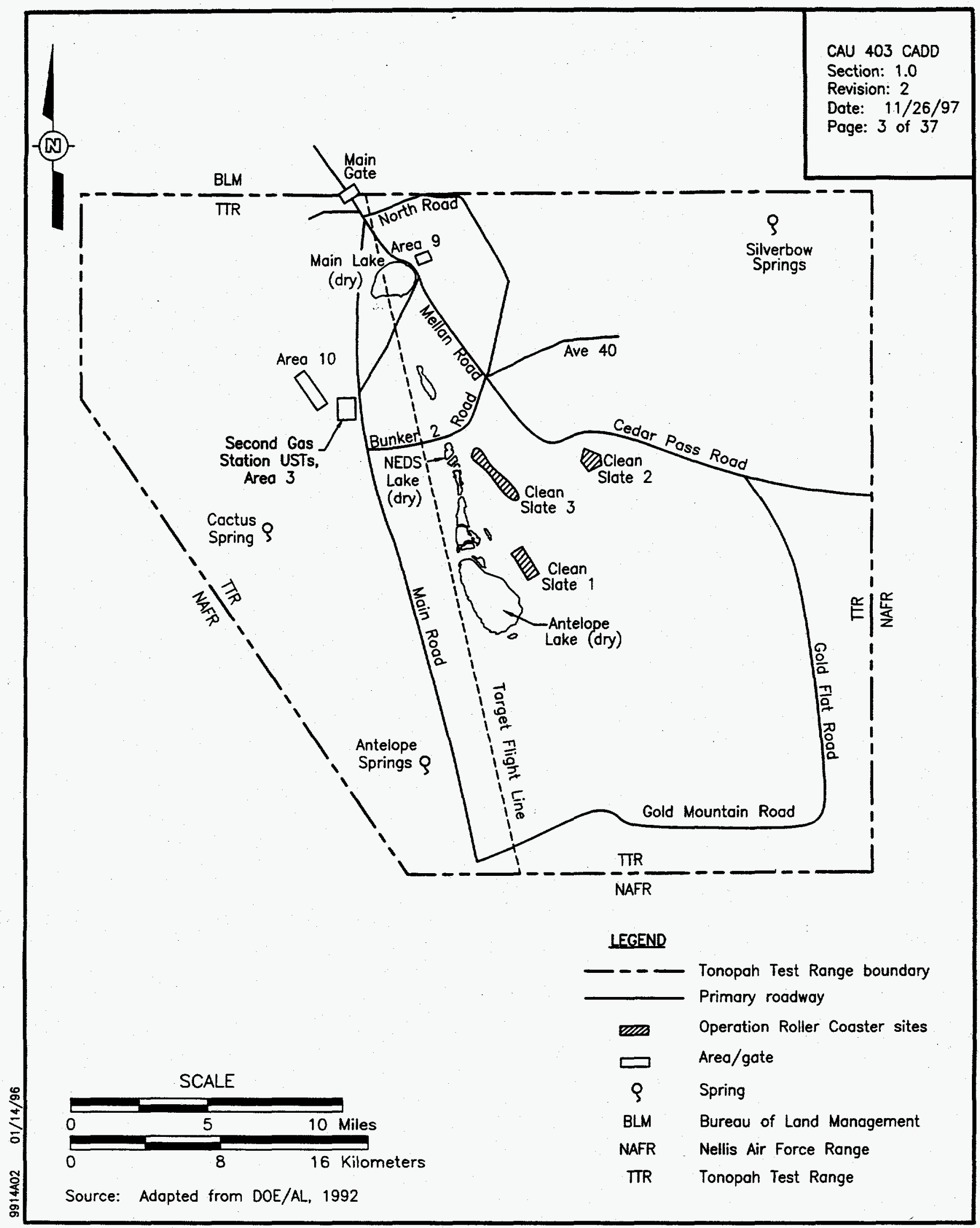

Figure 1-2

Location of the Second Gas Station, Area 3, Tonopah Test Range 


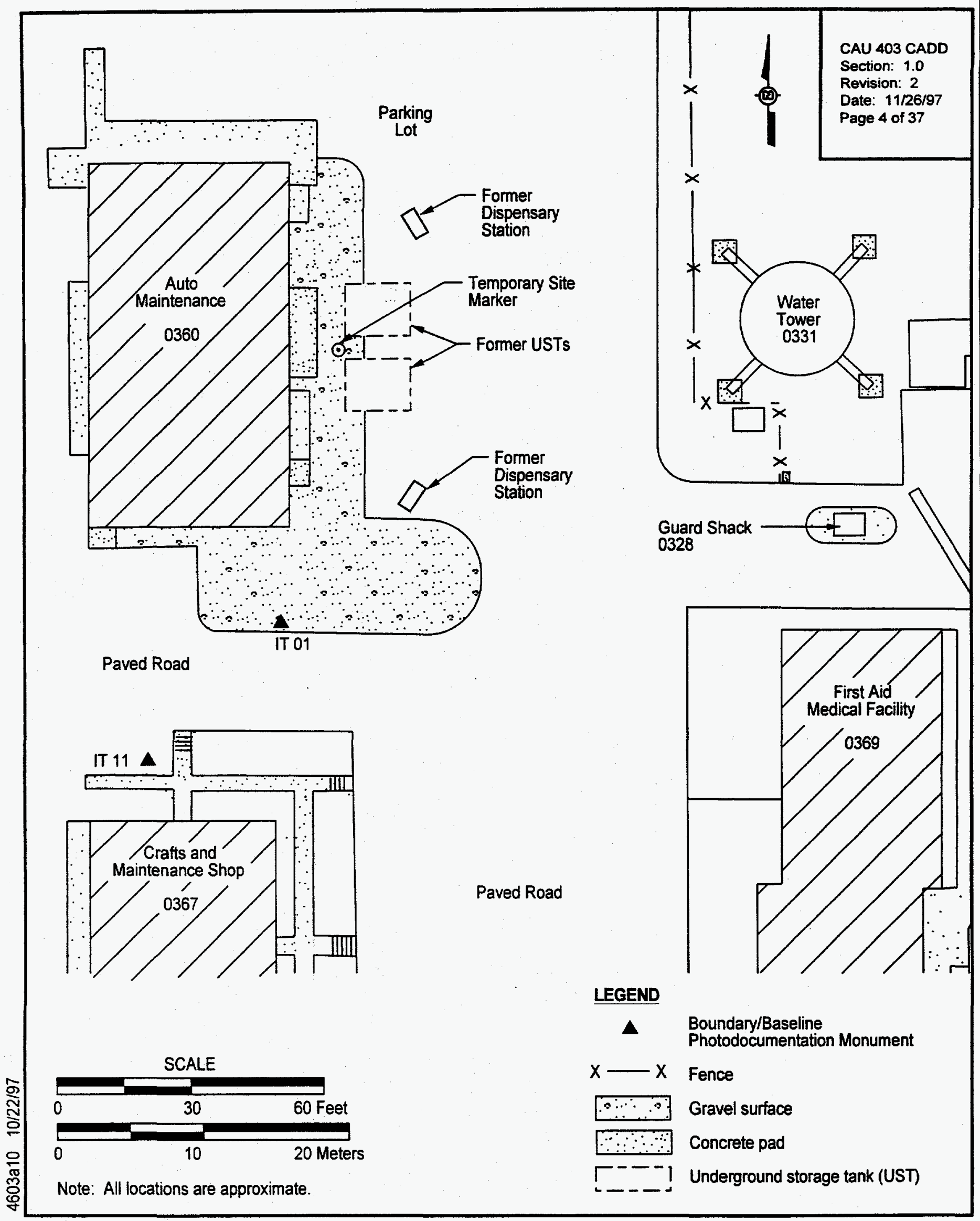

Figure 1-3

Original Site Map, Second Gas Station and Surrounding Facilities, Area 3, Tonopah Test Range 
investigation. Figure 1-4 depicts the tank configurations used in the subsequent investigation based on the new information. The location of the two dispensary stations has not changed.

Past corrective action activities included the excavation and removal of the two USTs. No records of the removal activities were identified; however, the two USTs and two dispensary stations were removed sometime between August 8, 1982, and June 13, 1987 (DOE/NV, 1996a). Historical information indicates that the associated piping entering and exiting the tanks was probably removed during tank excavation activities; however, the contaminated soil surrounding the tanks and dispensary stations may have been left in place (DOE NV, 1996a).

The diesel UST had a 16,000-liter (L) (4,000-gallon [gal]) capacity (DOE/NV, 1996a). During removal, a breach approximately 3 centimeters $(\mathrm{cm})(1$ inch [in.]) wide by $1.2 \mathrm{~m}(4 \mathrm{ft})$ long was observed about $0.3 \mathrm{~m}(1 \mathrm{ft})$ below the top of the tank. Whether this breach was caused during removal activities or was preexisting is not known. The soil surrounding the tank appeared visibly contaminated; however, the soil may or may not have been removed (DOE/NV, 1996a). No information was found regarding the construction or condition of the gasoline UST. The tank was removed at the same time as the diesel UST; no visible signs of contamination were observed in the surrounding soils.

A corrective action investigation was conducted in September 1996 and in September 1997 following Nevada Division of Environmental Protection (NDEP) approval of the CAIP (DOE, 1996a). All work was performed in accordance with the CAIP (DOE/NV, 1996a), the Industrial Sites Quality Assurance Project Plan (DOE/NV, 1996c), and the Corrective Action Unit Work Plan for the Tonopah Test Range (DOE/NV, 1996b). The objectives of the corrective action investigation were as follows:

- Collect data to confirm the absence or presence of contamination.

- Determine the lateral and vertical extent of contamination.

- Provide sufficient information to develop closure strategies for the site. 


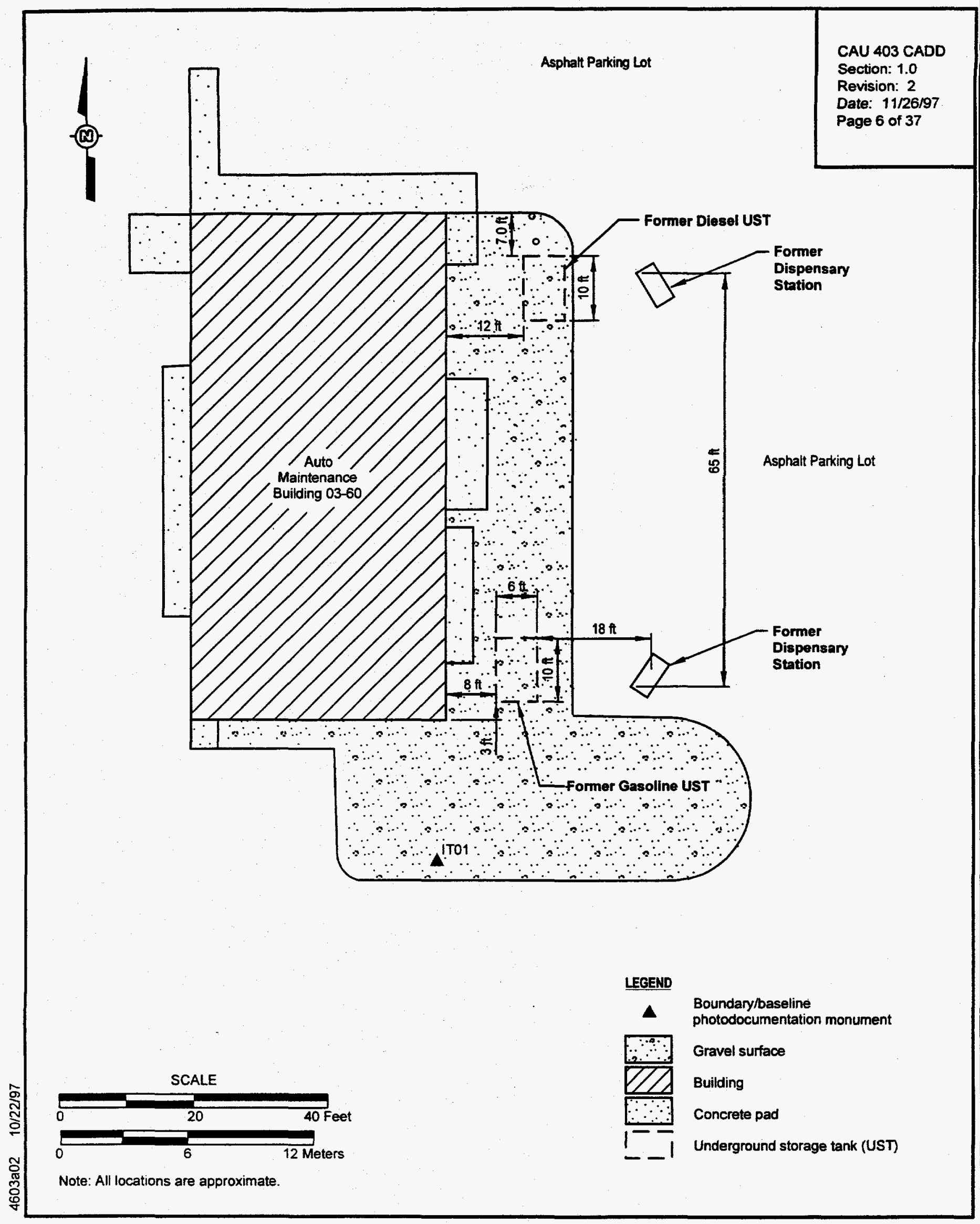

Figure 1-4

Current Site Map, Second Gas Station and Surrounding Facilities, Area 3, Tonopah Test Range 


\subsection{Purpose}

The purpose of this CADD is to identify and provide a rationale for the selection of a recommended corrective action alternative based on process knowledge and the results of the corrective action investigation activities at the Second Gas Station CAS.

\subsection{Scope}

The scope of this CADD consists of the identification, evaluation, and recommendation of a preferred corrective action alternative to be implemented at the Second Gas Station CAS. To achieve this scope, the following actions have been taken:

- Reviewed and discussed the current site conditions, including the nature and extent of contamination

- Developed corrective action objectives

- Identified corrective action alternative screening criteria (corrective action standards and remedy selection decision factors)

- Developed corrective action alternatives

- Performed detailed and comparative evaluations of the corrective action alternatives in relation to the corrective action objectives and screening criteria

- Recommended and justified a preferred corrective action alternative

\subsection{CADD Contents}

This CADD has been divided into the following sections:

- Section 1.0 - Introduction

- Summarizes the purpose and scope of this CADD

- Section 2.0 - Corrective Action Investigation Summary

- Provides the results of the investigation activities and the need for corrective action 
- Section 3.0 - Evaluation of Alternatives

- Documents the steps taken in determining a preferred corrective action alternative. This includes the following:

- Identification of corrective action objectives

- Identification of U.S. Environmental Protection Agency (EPA) alternative screening criteria

- Development of corrective action alternatives

- Evaluation and comparison of corrective action alternatives

- Section 4.0 - Recommended Alternative

- Presents the preferred corrective action alternative and the rationale for its selection based on the corrective action objectives and screening criteria

- Section 5.0 - References

- Presents a list of all referenced documents

- Appendix A - Second Gas Station Investigation Report, Corrective Action Unit No. 403, Tonopah Test Range

- Appendix B - Cost Estimates 


\subsection{Corrective Action Investigation Summary}

The following sections describe and summarize the results of the investigation activities conducted at the Second Gas Station CAS. Based on this information, corrective action objectives were identified to aid in the formation of corrective action alternatives.

\subsection{Investigation Activities}

In September 1996, a corrective action investigation, consisting of the following activities as set forth in the CAIP (DOE/NV, 1996a), was performed:

- Drilled twelve boreholes (Figure 2-1) and collected environmental surface and subsurface soil samples for field screening and laboratory analysis

- Field-screened samples using headspace analysis for volatiles and turbidimetric testing for total petroleum hydrocarbons (TPH)

- Analyzed environmental soil samples for TPH, lead, geotechnical, and bioassessment parameters

- Evaluated the condition of the subsurface soils to determine if contaminants of concern (COCs) were present

- Assessed the potential for downward migration of the COCs from potential source points through the underlying soils

- Determined if contamination was present and estimated the extent of contaminant migration in relation to the former locations of the tank and dispensary stations

- Evaluated the presence of excessive petroleum in soil at the site in accordance with Nevada Administrative Code (NAC) 459.9973.1, (a) through (k)

As a result of the updated former UST locations, an additional soil boring was required to investigate the underlying soils at the newly identified gasoline UST site (Figure 2-2). Investigation activities similar to those mentioned above were conducted in September 1997 in accordance with the CAIP (DOE/NV, 1996a). 


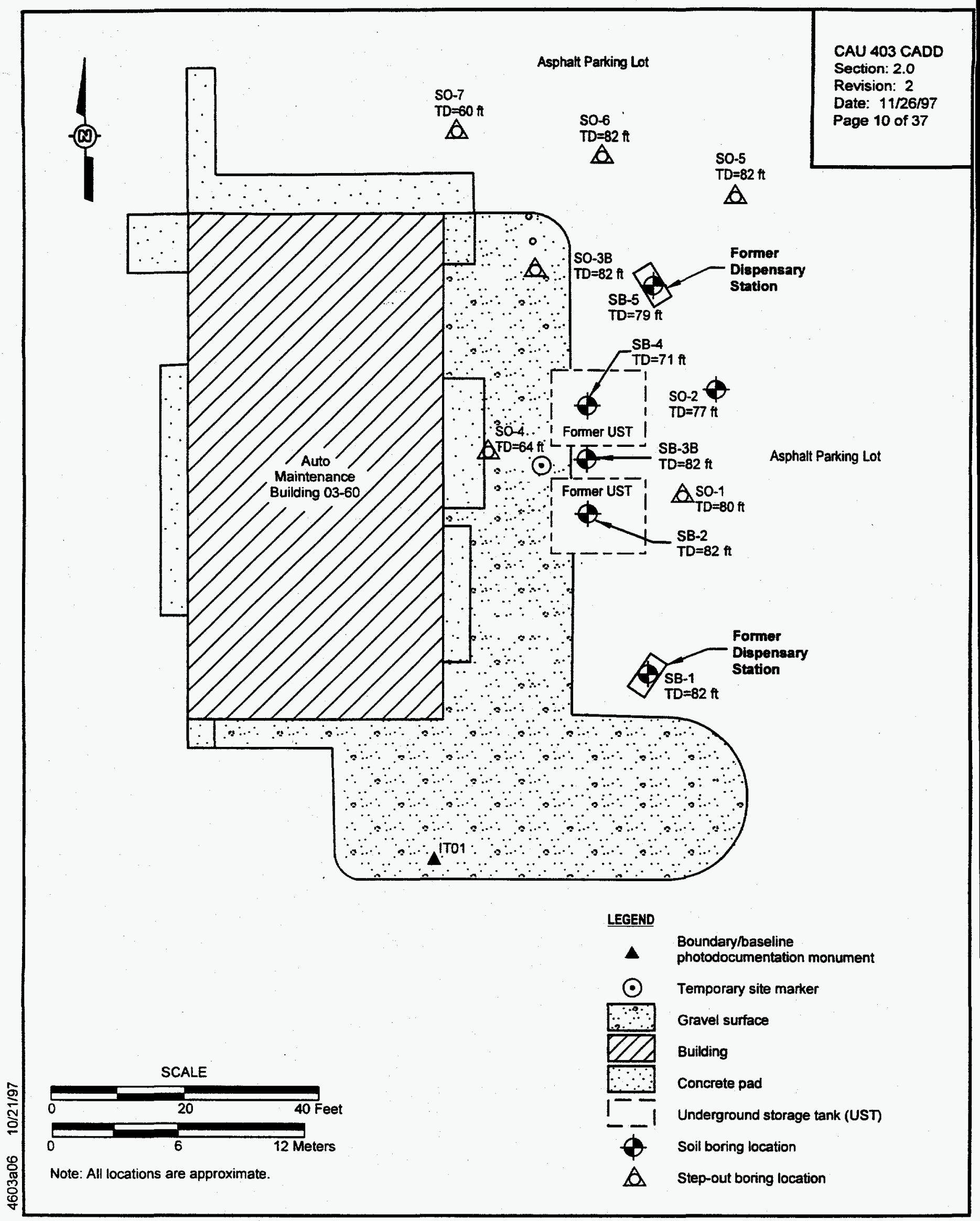

Figure 2-1

Original Second Gas Station Site Map 


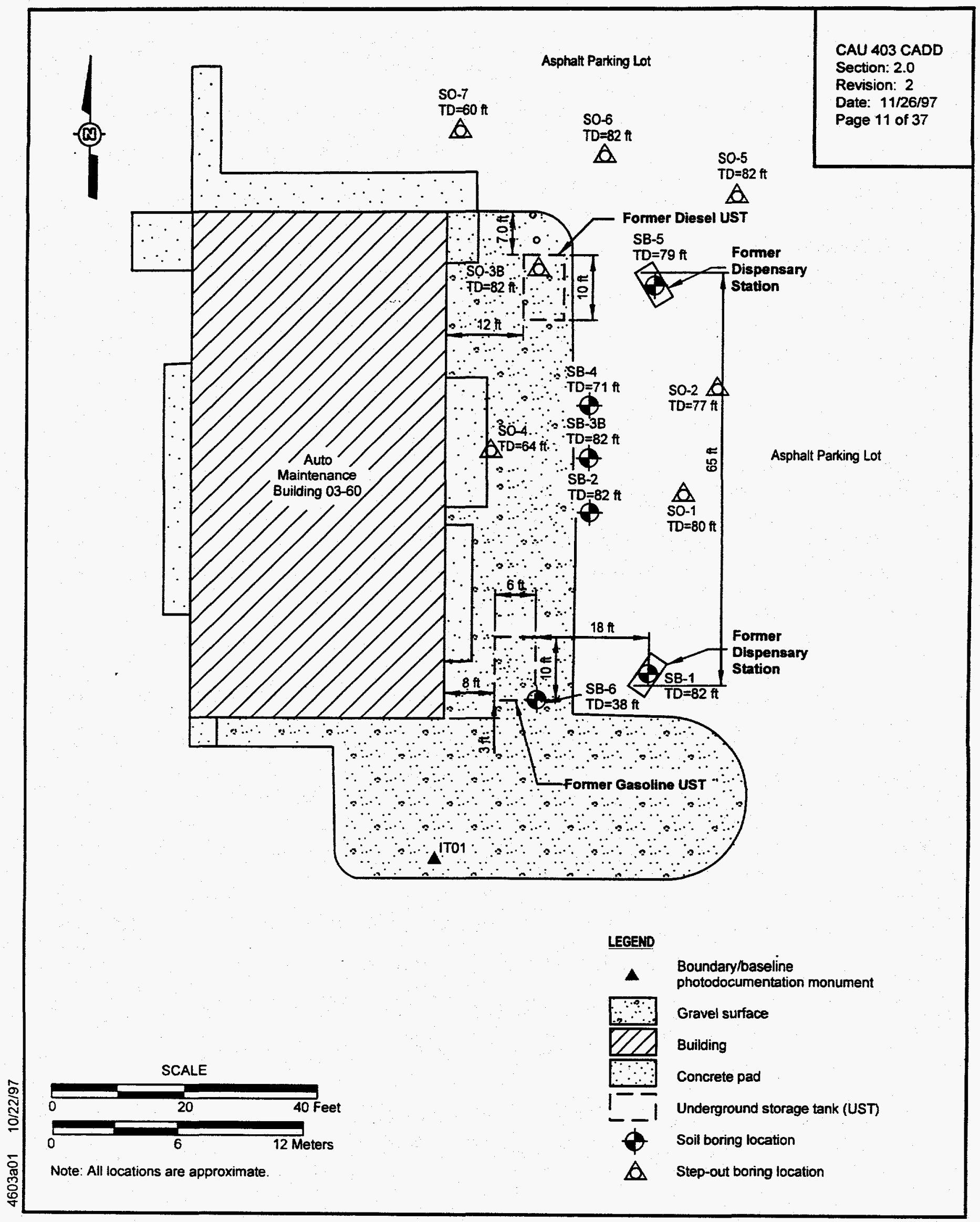

Figure 2-2

Current Second Gas Station Site Map 
The underlying soils at the newly identified diesel UST site were sufficiently characterized by soil boring SO-3B (Figure 2-2). Therefore, further investigation was not deemed necessary at the diesel UST site.

In addition, historical documents and process knowledge were used to assist in the identification of potential contaminants (see Appendix A).

\subsection{Results}

A summary of the corrective action investigation results indicated the following:

- TPH concentrations above the action levels of 100 parts per million (ppm) (Nevada Administrative Code 459) were detected in four of thirteen soil borings. The investigation report (Appendix A) contains the evaluation required by NAC 459 as a result of this finding.

- Viable microbial populations existed and appeared to be well-adapted to current conditions.

- Phosphate levels were high; ammonium levels were low; and $\mathrm{pH}$ and moisture content were within acceptable levels.

- The heterotrophic, hydrocarbon-degrading microbial population reacted favorably to oxygen and nutrient stimulation.

Details of the methods used and the results found during the investigation are presented in Appendix A.

\subsection{Need for Corrective Action}

The corrective action investigation identified TPH concentrations above the NDEP action level of $100 \mathrm{ppm}$; therefore, an evaluation of actions is required to ensure worker and public protection against exposure to the contamination. Approximately 1,200 cubic meters $\left(\mathrm{m}^{3}\right)(1,569$ cubic yards $\left.\left[\mathrm{yd}^{3}\right]\right)$ of TPH-impacted soils have been estimated based on results of the corrective action investigation. A maximum of $12,000 \mathrm{ppm}$ of TPH as diesel was identified at approximately $7 \mathrm{~m}$ $(22 \mathrm{ft})$ below land surface. Specific characteristics which may constrain remedial actions include:

- The underground utilities (electrical and communication lines) in the vicinity of the CAS could be disrupted by excavation or other corrective action activities. 
- Building B-0360 (Figure 2-2) is an active facility currently used for mechanical repairs. Corrective actions conducted at the facility must be coordinated with on-site personnel and must not compromise the structure. 


\subsection{Evaluation of Alternatives}

The purpose of this section is to present the corrective action objectives for the Second Gas Station CAS; to present and describe the general standards and decision factors used to screen the corrective action alternatives; to identify a baseline of proven, viable technologies; and to develop and evaluate a set of corrective action alternatives which could be used to meet the corrective action objectives.

\subsection{Corrective Action Objectives}

The identification of corrective action objectives is a critical prerequisite to the development of corrective action alternatives that will result in an acceptable level of environmental protection. The objectives of the corrective action to be implemented at the Second Gas Station CAS are to provide a remedy that protects human health and the environment, to eliminate the source of the contamination, and to ensure compliance with applicable waste management standards. In addition, the proposed corrective action must be technically sound, provide a permanent solution for the site, be cost-effective, and be acceptable to DOE, NDEP, and the public (NAC 459). The accepted action level for TPH is $100 \mathrm{ppm}$ (NAC 459). A trigger value of $10,000 \mathrm{ppm}$ TPH is used to assess the use of institutional (administrative) controls in conjuction with an evaluation of the NAC 459.9973, (a) through (k) criteria.

The corrective action objective has media-specific goals for protecting human health and the environment which constitute the basis for the development of corrective action alternatives. These goals are expressed in terms of contaminants, media of interest, potential exposure pathways, and cleanup goals so that an appropriate range of waste management options can be developed for analysis.

Based on the potential exposure pathways, the corrective action objective for the Second Gas Station CAS is the prevention or mitigation of potential human exposure to subsurface soils containing TPH at concentrations greater than 100 ppm (NAC 459). 


\subsubsection{Contaminants of Concern}

Analytes detected as a result of the investigation were evaluated to determine COCs. Based on the results of this evaluation, elevated levels of TPH as diesel, fuel oil, and/or gasoline were identified in four of thirteen soil borings above the NDEP action level of $100 \mathrm{ppm}$ (NAC 459). All other analyzed constituents were below the regulated levels. Process knowledge (Appendix A and DOE/NV, 1996a) indicates that the USTs, dispensary stations, and associated piping were removed, thereby mitigating further releases to the environment.

\subsubsection{Potential Exposure Pathways}

The Second Gas Station CAS is overlain with asphalt and gravel, which effectively removes potential exposure pathways and limits the amount of precipitation infiltration that could cause migration of contaminants in the shallow, TPH-impacted soils. Groundwater at the site is estimated to be 110 to $120 \mathrm{~m}$ (360 to $390 \mathrm{ft}$ ) below ground surface; no adverse groundwater impacts have been identified in downgradient sampling locations (Appendix A). Therefore, the only potential exposure pathway is through intrusive activities (e.g., digging) that breach the asphalt or gravel barriers. If the underlying soils are contaminated, the disturbance of the soils could result in a potentially harmful exposure to contaminated subsurface soils through incidental ingestion or dermal contact by workers or the public.

No ecological receptors are identified because the contamination is only located in the subsurface with asphalt and gravel preventing access to plants and animals.

\subsubsection{Preliminary Cleanup Goal}

The preliminary cleanup goal for the Second Gas Station CAS is the TPH action level of $100 \mathrm{ppm}$ as specified in NAC 459. The trigger level of $10,000 \mathrm{ppm}$ will be used to assess closure-in-place with administrative controls.

\subsection{Screening Criteria}

The screening criteria used to evaluate and select the corrective action alternatives consisted of general standards and decision factors described in State of Nevada requirements (NAC 459.9973) 
and the EPA guidance documents Guidance on Resource Conservation and Recovery Act (RCRA) Corrective Action Decision Documents (EPA, 1991) and the Final Resource Conservation and Recovery Act (RCRA) Corrective Action Plan (EPA, 1994).

The corrective action alternatives delineated in Section 3.3 were evaluated, based on four general corrective action standards and five remedy selection decision factors as described in the following text. All corrective action alternatives must meet the general standards to be selected for evaluation using the remedy selection decision factors.

The general corrective action standards are as follows:

- Attain overall protection of human health and the environment.

- Attain media cleanup standards.

- Control the source of the release(s).

- Comply with applicable standards for management of wastes as specified in NAC 459.9974.

The remedy selection decision factors are:

- Short-term reliability and effectiveness

- Reduction of toxicity, mobility, and/or volume

- Long-term reliability and effectiveness

- Implementability

- Cost

The general corrective action standards and decision factors required by guidance (EPA, 1991) are described in further detail in the following text.

\subsubsection{Overall Protection of Human Health and the Environment}

Protection of human health and the environment is a general mandate of the RCRA statute (EPA, 1994). This mandate requires that the corrective action include any measures that are needed to be protective. These measures may or may not be directly related to media cleanup, source control, or management of wastes. 


\subsubsection{Attain Media Cleanup Standards}

Each corrective action alternative must have the ability to meet the proposed media cleanup standards (NAC 459) (i.e., meet acceptable levels for removal of contaminants). Factors on which an evaluation of cleanup standards must be based (NAC 459.9973) are addressed in Appendix A.

\subsubsection{Control the Sources of the Release}

A critical objective of any corrective action must be to stop further environmental degradation by controlling or eliminating further releases that may pose a threat to human health and the environment. Unless source control measures are taken, efforts to clean up releases may be ineffective or, at best, will essentially involve a perpetual cleanup. Therefore, each corrective action alternative must use an effective source control program to ensure the long-term effectiveness and protectiveness of the corrective action effort.

\subsubsection{Comply with Applicable Standards for Management of Wastes}

During implementation of any corrective action alternative, all waste management activities must be conducted in accordance with all applicable state and federal regulations (e.g., RCRA Title 40 Code of Federal Regulations [CFR] land disposal restrictions [CFR, 1996] and NAC 459.9974, "Disposal and Evaluation of Contaminated Soil" [NAC, 1996]). The requirements for management of the wastes, if any, derived from the corrective action investigation will be determined based on the regulatory requirements listed above, field observations, process knowledge, and the results of laboratory analyses. Administrative controls (e.g., decontamination procedures and characterization strategies) will minimize waste generated during site corrective action activities. Decontamination activities shall be performed in accordance with procedures as specified in the NDEP-approved TTR work plan (DOE/NV, 1996b) and will be designated according to the COCs present at the site. Waste management practices are detailed in the following text. 


\subsubsection{Waste Minimization}

The corrective action activities will be designed to minimize the amount of solid investigation-derived waste produced. Waste produced will include excavated soil, used personal protective equipment, and decontamination waste.

\subsubsection{Potential Waste Streams}

Based on the corrective action investigation activities and process knowledge, no radioactive, hazardous, or mixed wastes are anticipated. Solid waste would consist of general construction debris, asphalt, hydrocarbon-contaminated soil, disposable personnel protective equipment, and sampling equipment.

\subsubsection{Waste Determination}

Solid materials other than soils are waste only by virtue of contact with contaminated media. Therefore, sampling and analysis of any investigation-derived waste, separate from verification analyses, should not be required during corrective action activities.

\subsubsection{Waste Management}

Because the waste will consist of general construction debris, asphalt, hydrocarbon-contaminated soil, disposable personnel protective equipment, and sampling equipment, it will be managed in accordance with NAC 459.9974 .

\subsubsection{Short-Term Reliąbility and Effectiveness}

Each corrective action alternative must be evaluated with respect to its effects on human health and the environment during the construction and implementation phases of the corrective action. The following factors will be addressed for each alternative:

- Protection of the community to address any risk that results from implementation such as fugitive dusts, transportation of hazardous materials, or air-quality impacts from off-gas emissions 
- Protection of workers during construction and implementation

- Environmental impacts which may result from construction and implementation

- The amount of time until corrective action objectives are achieved

\subsubsection{Reduction of Toxicity, Mobility, and/or Volume}

Each corrective action alternative must be evaluated for its ability to reduce the toxicity, mobility, and/or volume of the contaminated media. Reduction in toxicity, mobility, and/or volume refers to changes in one or more characteristics of the contaminated media by the use of corrective measures that decrease the inherent threats associated with the media.

\subsubsection{Long-Term Reliability and Effectiveness}

Each corrective action alternative must be evaluated in terms of risk remaining at the site after corrective action alternatives have been met. The primary focus of this evaluation will be on the extent and effectiveness of the controls that may be required to manage risk posed by treatment residuals and/or untreated wastes.

\subsubsection{Implementability}

The implementability criterion addresses the technical and administrative feasibility of implementing a corrective action alternative and the availability of various services and materials needed during implementation. Each corrective action alternative must be evaluated for the following criteria:

- Construction and Operation: This refers to the feasibility of implementing a corrective action alternative given the existing set of waste and site-specific conditions.

- Administrative Feasibility: This refers to the administrative activities needed to implement the corrective action alternative (e.g., permits, public acceptance, rights of way, off-site approval).

- Availability of Services and Materials: This refers to the availability of adequate off-site and on-site treatment, storage capacity, disposal services, needed technical services and materials, and availability of prospective technologies for each corrective action alternative. 


\subsubsection{Cost}

The cost estimate for each corrective action alternative will include both capital and operation and maintenance costs, if applicable. A brief description of both components of these costs is as follows:

- Capital Costs: These costs include both direct and indirect costs. Direct costs may consist of materials, labor, mobilization, demobilization, site preparation, construction materials, equipment purchase and rentäl, sampling and analysis, waste disposal, and health and safety measures. Indirect costs include such items as engineering design, permits and/or fees, start-up costs, and any contingency allowances.

- Operation and Maintenance: These costs include labor, training, sampling and analysis, maintenance materials, utilities, and health and safety measures.

A net present worth will be calculated for each corrective action alternative if long-term operation and maintenance are required. Details of the estimated costs are presented in Appendix B.

\subsection{Development of Corrective Action Alternatives}

This section identifies and describes the potential and viable corrective action technologies considered for the affected media.

\subsubsection{Identification of Corrective Action Technologies}

Technologies considered most viable for implementation at the Second Gas Station CAS are:

- Institutional controls

- Excavation

- Off-site disposal

- In situ bioremediation

Other technologies and "innovative technologies" were considered in the identification process; however, the selected technologies were chosen as the most appropriate based on current CAS conditions. They are representative of three general categories, institutional controls, in situ remediation, and ex situ remediation. 


\subsubsection{Institutional Controls}

Institutional controls are administrative controls or physical barriers used to prevent contact with contaminated material. Institutional controls can consist of land-use restrictions, water-rights restrictions, and restrictions on activities such as digging. In addition, signs and fencing can be used to further restrict access. Institutional controls are commonly used and are effective at eliminating potential pathways, especially in sites that already have restricted access. The implementation of institutional controls requires the coordination of all entities at a site to ensure that the restrictions are enforced.

\subsubsection{Excavation}

Excavation is the process of removing soils and other materials with construction equipment such as front-end loaders, backhoes, and excavators. Excavation is a well-developed technology commonly used in the mining and construction industry and is often used for remediation of shallow subsurface soils. Excavation equipment is commercially available with optional equipment for unique applications, for example, a telescopic excavator boom. Standard excavation equipment is capable of handling a wide range of materials (including rock, gravel, asphalt, and bulk materials) at relatively high capacities.

The removal of contaminated soils is assumed to continue until post-excavation verification soil samples taken at the bottom of the excavation meet cleanup standards (assumed to be the TPH action level of $100 \mathrm{ppm}$ for this technology). The excavated areas will be backfilled with uncontaminated soils, recontoured to eliminate topographic depressions, and returned to preexisting conditions by placement of asphalt pavement.

\subsubsection{Off-Site Disposal}

Off-site disposal includes the packaging, transportation, and treatment and/or disposal of TPH-contaminated soils generated during corrective action activities. These soils are disposed of at an approved off-site landfill or treatment facility (i.e., landfarm or incinerator). This remedial technology is accepted by the EPA and is commonly used in industry. Off-site disposal costs are dependent on the distance to the disposal facility and the classification of the soils. Generally, heavy 
equipment (i.e., front end loaders) and manual labor (i.e., shoveling) will be used to load the waste into the appropriate containers or directly onto the trucks.

\subsubsection{In Situ Bioremediation}

Bioremediation is a process which uses aerobic and anaerobic microorganisms, bacteria, fungi, and/or actinomycetes to degrade and detoxify contaminants. Degradation involves the breakdown of contaminants into simpler intermediate compounds that may or may not be less toxic. These intermediate compounds may themselves be further degraded. If the final degradation process results in only carbon dioxide and water as end products, degradation will be considered complete. The process is particularly effective for simple aliphatic and aromatic, nonchlorinated organics. For more complex or chlorinated organics or in nutrient-depleted areas, special cultures and nutrient supplements can be introduced.

In situ bioremediation can be applied to the vadose zone below the Second Gas Station CAS by attaching injection wells to a blower and injecting air into the contaminated subsurface soils (i.e., active system). Additionally, nutrients such as ammonia gas can be injected, if necessary, into the subsurface soils to increase the efficiency of the biodegradation process.

In situ bioremediation is used here to represent a range of in situ treatment options ranging from simple passive bioremediation to more active systems with hybrid vapor and nutrient injection in order to provide a comparison with the other alternatives. The final design of the system (i.e., size of the pumping equipment, frequency of monitoring, and requirements for additives) will be specified in the Corrective Action Plan prior to implementation.

\subsubsection{Corrective Action Alternatives}

The corrective action technologies presented in Section 3.3.1 are viable for use in the remediation of the Second Gas Station CAS and have proven effective at other sites with similar contaminants and conditions. Combinations of these candidate technologies have been assembled into specific corrective action alternatives that have the potential to meet the stated corrective action objectives. 
Based on the review of existing data and current operations at the TTR, the following corrective action alternatives have been developed for consideration in the remediation of the Second Gas Station CAS:

- Alternative 1 - No action (for baseline comparison only)

- Alternative 2 - Institutional controls

- Alternative 3 - Excavation and off-site disposal

- Alternative 4 - In situ bioremediation

An overview of these alternatives is presented in the following text.

\subsubsection{Alternative 1 - No Action}

Under the no-action alternative, no corrective action activities will be implemented. This alternative is used as a starting point for comparison with the other alternatives. This alternative does not provide protection against intrusion into the contaminated zone; therefore, it will not be evaluated using the selection decision factors.

\subsubsection{Alternative 2 - Institutional Controls}

This alternative consists of administrative controls against intrusion into the contaminated soils and the requirement for appropriate health and safety protections in the event of unavoidable intrusive activities such as repairing or replacing utilities in the area. In addition, signs and fences would be used as necessary to limit breaches of the asphalt and soil covers. Based on data from the investigation at the CAS, the biological environment is favorable to natural biological degradation. Some degree of natural biological activity may result in reduced concentrations of hydrocarbons with time. Implementation of institutional controls requires coordination with all entities at the site including Sandia National Laboratories and the U.S. Air Force. An evaluation of the NAC 459.9973.1, (a) through $(\mathrm{k})$, requirements is presented in Appendix A; this evaluation provides evidence that conditions at the site will not adversely impact the groundwater beneath the site or any nearby drinking water wells. 


\subsubsection{Alternative 3 - Excavation and Off-Site Disposal}

This alternative consists of excavation, packaging, transportation, and disposal of TPH-contaminated soils and the asphalt covering from the Second Gas Station CAS to an off-site location.

Under this alternative, commercially available equipment will be used to excavate an estimated 1,200 $\mathrm{m}^{3}\left(1,570 \mathrm{yd}^{3}\right)$ of TPH-impacted soils at the Second Gas Station CAS. These soils, and the asphalt covering them, will be packaged and transported by private carrier to an approved, off-site landfill. The soils will be placed directly in the landfill or treated in a landfarming area or incinerator. Based on the process knowledge indicated in Appendix A, the soils are assumed to contain only TPH and to be acceptable for treatment (i.e., landfarming or incineration) and/or direct disposal at an off-site landfill.

Approximately $1,500 \mathrm{~m}^{3}\left(1,962 \mathrm{yd}^{3}\right)$ of clean borrow soil will be placed in the surface depressions caused by the excavation activities, compacted, and brought to grade. Asphalt paving will be placed over the graded area and gravel-covered portions of the site, thereby providing an impermeable barrier.

\subsubsection{Alternative 4 - In Situ Bioremediation}

The major component of this alternative will consist of in situ bioremediation of the TPH-contaminated shallow subsurface soils. An in situ bioremediation system consisting of one active injection well and one passive extraction well will be installed on either side of the contaminated area to remediate the shallow subsurface soils. The injection well will be piped to an air injection compressor fitted with an ammonia injection regulating system. Using a rough estimate of approximately one percent reduction per day, the time estimated for an active system to reduce the contaminant levels below regulatory levels is about two years. This alternative will require air monitoring during the life of the system. Generally, the monitoring consists of air monitoring at the passive extraction well for TPH. When monitoring indicates that the action levels (i.e., $100 \mathrm{ppm}$ TPH) have been achieved or that the system has reached the point of diminishing returns, confirmation borings will be drilled and sampled to verify that the vadose zone was cleaned to a level that complies with NDEP regulations (NAC 459). Once cleanup goals have been achieved, 
or concentrations have reached asymptomatic levels (as agreed to by the parties), the in situ bioremediation wells will be destroyed in accordance with NAC 534.421.

In addition, fencing will be erected around the in situ bioremediation system to prevent access to the site during the remedial action.

\subsection{Evaluation and Comparison of Alternatives}

The general corrective action standards and remedy selection decision factors described in Section 3.2 were used to conduct a detailed evaluation of each corrective action alternative. In addition, each corrective action alternative was compared to the other alternatives. In this way the advantages and disadvantages of each alternative were assessed in order to select a preferred alternative. Table 3-1 and Table 3-2 present a summary of the detailed and comparative analysis evaluations, respectively. 
Table 3-1

Detailed Evaluation of the Corrective Action Alternatives (Sheet 1 of 4)

\begin{tabular}{|c|c|c|c|c|}
\hline $\begin{array}{c}\text { Evaulation } \\
\text { Criteria }\end{array}$ & $\begin{array}{l}\text { Alternative } 1 \\
\text { No Action }\end{array}$ & $\begin{array}{c}\text { Alternative } 2 \\
\text { Institutional Controls }\end{array}$ & $\begin{array}{c}\text { Alternative } 3 \\
\text { Excavation and Disposal }\end{array}$ & $\begin{array}{c}\text { Alternative } 4 \\
\text { In Situ Bioremediation }\end{array}$ \\
\hline \multicolumn{5}{|c|}{ General Standards } \\
\hline $\begin{array}{l}\text { Overall } \\
\text { Protection of } \\
\text { Human Health } \\
\text { and the } \\
\text { Environment }\end{array}$ & $\begin{array}{l}\text { No risk assessment has been } \\
\text { conducted. However, contaminant } \\
\text { levels of TPH have been identified } \\
\text { above the NDEP action level. } \\
\text { Contaminants in the subsurface soils } \\
\text { are overlain with asphalt pavement; } \\
\text { therefore, there is a lack of } \\
\text { completed exposure pathways } \\
\text { unless intrusive activities are } \\
\text { undertaken. Protection to the public } \\
\text { will remain high because the TTR is a } \\
\text { restricted access facility. }\end{array}$ & $\begin{array}{l}\text { No risk assessment has been } \\
\text { conducted. However, contaminant } \\
\text { levels of TPH have been identified } \\
\text { above the NDEP action level. } \\
\text { Contaminants in the subsurface soils } \\
\text { are overlain with asphalt pavement. } \\
\text { Institutional controls will prevent } \\
\text { intrusive activities. Protection to the } \\
\text { public will remain high because the } \\
\text { TTR is a restricted access facility. }\end{array}$ & $\begin{array}{l}\text { No risk assessment has been } \\
\text { conducted. TPH-contaminated } \\
\text { subsurface soils above the NDEP } \\
\text { action level of } 100 \mathrm{ppm} \text { are present. } \\
\text { Worker exposure to the contaminants } \\
\text { will be controlled during excavation } \\
\text { activities through implementation of } \\
\text { appropriate health and safety } \\
\text { procedures. }\end{array}$ & $\begin{array}{l}\text { No risk assessment has been } \\
\text { conducted. TPH-contaminated } \\
\text { subsurface soils above the NDEP } \\
\text { action level of } 100 \mathrm{ppm} \text { are present: } \\
\text { Worker exposure to the contaminants } \\
\text { will be controlled during drilling and } \\
\text { system operation through } \\
\text { implementation of appropriate health } \\
\text { and safety procedures. Air } \\
\text { monitoring will be conducted during } \\
\text { operation. }\end{array}$ \\
\hline $\begin{array}{l}\text { Attain Media } \\
\text { Cleanup } \\
\text { Standards }\end{array}$ & $\begin{array}{l}\text { No corrective actions are proposed. } \\
\text { Subsurface soils will remain in place } \\
\text { with TPH concentrations above the } \\
\text { action level. Some natural biological } \\
\text { activity will likely result in lower } \\
\text { concentrations over time; however, } \\
\text { no protections are provided to } \\
\text { prevent human exposure to the } \\
\text { elevated concentrations through } \\
\text { instrusive activities. NAC } 459.9973 \text {, } \\
\text { (a) through (k) analysis, shows the } \\
\text { contaminants are not impacting } \\
\text { groundwater. }\end{array}$ & $\begin{array}{l}\text { No treatment actions are proposed. } \\
\text { Subsurface soils will remain in place } \\
\text { with TPH concentrations above } \\
\text { action levels. Some natural } \\
\text { biological activity will likely result in } \\
\text { lower concentrations over time, and } \\
\text { protections are provided to prevent } \\
\text { human exposure to the contaminated } \\
\text { soils through intrusive activities. } \\
\text { NAC } 459.9973 \text {, (a) through (k) } \\
\text { analysis, shows the contaminants are } \\
\text { not impacting groundwater. The } \\
\text { levels identified do not significantly } \\
\text { exceed the } 10,000 \text { ppm trigger level } \\
\text { for corrective action. }\end{array}$ & $\begin{array}{l}\text { TPH-contaminated subsurface soils } \\
\text { above the NDEP action level will be } \\
\text { excavated and disposed off site. } \\
\text { Cleanup standards will be verified } \\
\text { with confirmation soil sampling. }\end{array}$ & $\begin{array}{l}\text { TPH in the shallow subsurface soils } \\
\text { will be reduced to acceptable levels } \\
\text { through in situ bioremediation. The } \\
\text { contaminants will be reduced to } \\
\text { harmless end products (i.e., carbon } \\
\text { dioxide and water). The cleanup } \\
\text { standard will be achieved when the } \\
\text { residual vadose zone contaminants } \\
\text { are below the NDEP action levels of } \\
100 \text { ppm or at the point of diminishing } \\
\text { returns. NAC } 459.9973 \text {, (a) through } \\
\text { (k) analysis, shows the contaminants } \\
\text { are not impacting groundwater. }\end{array}$ \\
\hline
\end{tabular}


Table 3-1

Detailed Evaluation of the Corrective Action Alternatives (Sheet 2 of 4 )

\begin{tabular}{|c|c|c|c|c|}
\hline $\begin{array}{l}\text { Evaulation } \\
\text { Criteria }\end{array}$ & $\begin{array}{l}\text { Alternative } 1 \\
\text { No Action }\end{array}$ & $\begin{array}{c}\text { Alternative } 2 \\
\text { Institutional Controls }\end{array}$ & $\begin{array}{l}\text { Alternative } 3 \\
\text { Excavation and Disposal }\end{array}$ & $\begin{array}{c}\text { Alternative } 4 \\
\text { In Situ Bioremediation }\end{array}$ \\
\hline \multicolumn{5}{|c|}{ General Standards } \\
\hline $\begin{array}{l}\text { Control the } \\
\text { Source of the } \\
\text { Release(s) }\end{array}$ & $\begin{array}{l}\text { TPH-contaminated subsurface soils } \\
\text { remain above NDEP action levels. } \\
\text { The sources of the contamination } \\
\text { (i.e., leakage from USTs and } \\
\text { dispensary station piping) have been } \\
\text { previously removed. There is no } \\
\text { control of contaminant migration } \\
\text { through potential contact with the } \\
\text { soils. NAC459.9973, (a) through (k) } \\
\text { analysis, show migration to be } \\
\text { limited. Because asphalt pavement } \\
\text { overlies a majority of the site, } \\
\text { potential exposure pathways are } \\
\text { removed, and precipitation infiltration } \\
\text { is minimized. The TTR is a restricted } \\
\text { access area which effectively } \\
\text { controls access to the public. }\end{array}$ & $\begin{array}{l}\text { TPH-contaminated subsurface soils } \\
\text { remain above NDEP action levels. } \\
\text { The sources of the contamination } \\
\text { (i.e., leakage from USTs and } \\
\text { dispensary station piping) have been } \\
\text { previously removed. There is no } \\
\text { control of contaminant migration } \\
\text { through potential contact with the } \\
\text { soils. NAC459.9973, (a) through (k) } \\
\text { analysis, show migration to be } \\
\text { limited. Because asphalt pavement } \\
\text { overlies a majority of the site, } \\
\text { potential exposure pathways are } \\
\text { removed and precipitation infiltration } \\
\text { is minimized. The TTR is a restricted } \\
\text { access area which effectively } \\
\text { controls access to the public. } \\
\text { Institutional controls will prevent } \\
\text { spread of contaminants through } \\
\text { inadvertant intrusion to the } \\
\text { contaminated soils. }\end{array}$ & $\begin{array}{l}\text { The sources of the contamination } \\
\text { (i.e., leakage from USTs and } \\
\text { gasoline dispensary station piping) } \\
\text { have been previously removed. } \\
\text { TPH-contaminated subsurface soils } \\
\text { above NDEP action levels will be } \\
\text { excavated and transported to an off- } \\
\text { site, controlled facility for treatment } \\
\text { and/or disposal. }\end{array}$ & $\begin{array}{l}\text { The sources of the contamination } \\
\text { (i.e., leakage from USTs and } \\
\text { gasoline dispensary station piping) } \\
\text { have been previously removed. The } \\
\text { TPH-contaminated subsurface soils } \\
\text { will remain in place where } \\
\text { bioremediation treatment will reduce } \\
\text { TPH to harmless end products and } \\
\text { acceptable levels (i.e., } 100 \text { ppm). }\end{array}$ \\
\hline $\begin{array}{l}\text { Comply with } \\
\text { Standards for } \\
\text { Management of } \\
\text { Wastes }\end{array}$ & $\begin{array}{l}\text { No soils are removed from or } \\
\text { remediated at the site. Natural } \\
\text { attenuation will likely result in lower } \\
\text { concentrations over time. }\end{array}$ & $\begin{array}{l}\text { No soils are removed from or } \\
\text { remediated at the site. Natural } \\
\text { attenuation will likely result in lower } \\
\text { concentrations over time. }\end{array}$ & $\begin{array}{l}\text { TPH-contaminated soils will be } \\
\text { excavated until NDEP action levels of } \\
100 \mathrm{ppm} \text { are achieved. Excavation } \\
\text { and disposal will be consistent with } \\
\text { applicable regulations (NAC } \\
\text { 459.9974). }\end{array}$ & $\begin{array}{l}\text { In situ bioremediation will be } \\
\text { consistent with applicable state } \\
\text { regulations (NAC } 459 \text { ). } \\
\text { Bioremediation will continue until } \\
\text { action levels (i.e., } 100 \text { ppm) are } \\
\text { achieved or diminishing returns allow } \\
\text { the system to be shut down. }\end{array}$ \\
\hline
\end{tabular}


Table 3-1

Detailed Evaluation of the Corrective Action Alternatives (Sheet 3 of 4 )

\begin{tabular}{|c|c|c|c|c|}
\hline $\begin{array}{l}\text { Evaulation } \\
\text { Criteria }\end{array}$ & $\begin{array}{l}\text { Alternative } 1 \\
\text { No Action }\end{array}$ & $\begin{array}{c}\text { Alternative } 2 \\
\text { Institutional Controls }\end{array}$ & $\begin{array}{c}\text { Alternative } 3 \\
\text { Excavation and Disposal }\end{array}$ & $\begin{array}{c}\text { Alternative } 4 \\
\text { In Situ Bioremediation }\end{array}$ \\
\hline \multicolumn{5}{|c|}{ General Standards } \\
\hline $\begin{array}{l}\text { Short-Term } \\
\text { Reliability and } \\
\text { Effectiveness }\end{array}$ & Not Applicable & $\begin{array}{l}\text { Institutional controls are reliable and } \\
\text { effective in the short term. Worker } \\
\text { safety is not impacted because no } \\
\text { instrusion into the contamination is } \\
\text { proposed and no significant field } \\
\text { activities are required. The controls } \\
\text { will be effective immediately upon } \\
\text { implementation. Requires } \\
\text { coordination with the Air Force and } \\
\text { other site entities. }\end{array}$ & $\begin{array}{l}\text { Potential releases of fugitive dust and } \\
\text { contact with the TPH-contaminated } \\
\text { soils during excavation activities will } \\
\text { be mitigated by implementing } \\
\text { appropriate health and safety } \\
\text { procedures. Corrective action } \\
\text { objectives will be achieved upon } \\
\text { completion of excavation activities. } \\
\text { The potential for vehicle and heavy } \\
\text { equipment accidents increases with } \\
\text { this alternative. }\end{array}$ & $\begin{array}{l}\text { Potential releases of fugitive dust } \\
\text { during drilling and construction will be } \\
\text { mitigated by implementing } \\
\text { appropriate health and safety } \\
\text { procedures. Field tests performed at } \\
\text { the site revealed that some } \\
\text { parameters (e.g., soil pH, nutrients, } \\
\text { and moisture content) were within } \\
\text { acceptable limits and that some } \\
\text { degree of hydrocarbon } \\
\text { biodegradation had taken place. } \\
\text { However, site-specific pilot tests } \\
\text { should be conducted prior to } \\
\text { implementation of the remediation } \\
\text { system. Corrective action objectives } \\
\text { will be achieved in approximately two } \\
\text { years after implementation of this } \\
\text { corrective action alternative. }\end{array}$ \\
\hline $\begin{array}{l}\text { Reduction of } \\
\text { Toxicity, } \\
\text { Mobility, and/or } \\
\text { Volume }\end{array}$ & Not Applicable & $\begin{array}{l}\text { While no treatment processes are } \\
\text { proposed, natural attenuation could } \\
\text { result in a decrease in toxicity, } \\
\text { mobility, and volume. NAC } \\
459.9973 \text {, (a) through (k) analysis, } \\
\text { show the contaminants are not } \\
\text { significantly migrating, and they pose } \\
\text { little impact to human health, the } \\
\text { environment, or the groundwater. }\end{array}$ & $\begin{array}{l}\text { Subsurface soils containing TPH will } \\
\text { be excavated and transported to an } \\
\text { off-site facility. This reduces the } \\
\text { mobility by disposing in a safer } \\
\text { condition. Toxicity and volume are } \\
\text { reduced at the site; however, the } \\
\text { material is not treated to reduce } \\
\text { either the toxicity or volume. These } \\
\text { will gradually reduce through natural } \\
\text { processes. These processes may } \\
\text { result in slower or quicker action } \\
\text { depending on conditions at the } \\
\text { disposal site. }\end{array}$ & $\begin{array}{l}\text { The toxicity, mobility, and volume of } \\
\text { the TPH-contaminated shallow } \\
\text { subsurface soils will be reduced. } \\
\text { Bioremediation will reduce } \\
\text { constituents to harmless end } \\
\text { products. Contaminant reduction } \\
\text { through bioremediation is } \\
\text { irreversible. }\end{array}$ \\
\hline
\end{tabular}


Table 3-1

Detailed Evaluation of the Corrective Action Alternatives (Sheet 4 of 4 )

\begin{tabular}{|c|c|c|c|c|}
\hline $\begin{array}{l}\text { Evaulation } \\
\text { Criteria }\end{array}$ & $\begin{array}{c}\text { Alternative } 1 \\
\text { No Action }\end{array}$ & $\begin{array}{c}\text { Alternative } 2 \\
\text { Institutional Controls }\end{array}$ & $\begin{array}{l}\text { Alternative } 3 \\
\text { Excavation and Disposal }\end{array}$ & $\begin{array}{c}\text { Alternative } 4 \\
\text { In Situ Bioremediation }\end{array}$ \\
\hline \multicolumn{5}{|c|}{ General Standards } \\
\hline $\begin{array}{l}\text { Long-Term } \\
\text { Reliability and } \\
\text { Effectiveness }\end{array}$ & Not Applicable & $\begin{array}{l}\text { The controls will be required for an } \\
\text { extended period; however, the risk of } \\
\text { exposure is very low. The controls } \\
\text { are reliable and effective in the long } \\
\text { term, especially in conjuction with } \\
\text { current site access restrictions. If } \\
\text { access restrictions are removed, } \\
\text { additional controls may be required. } \\
\text { This alternative requires coordination } \\
\text { with all entities at the site. }\end{array}$ & $\begin{array}{l}\text { Following completion of the } \\
\text { excavation activities, the CAU will be } \\
\text { closed. No monitoring will be } \\
\text { required. }\end{array}$ & $\begin{array}{l}\text { Performance monitoring of the in situ } \\
\text { bioremediation system will be } \\
\text { conducted during system operation. }\end{array}$ \\
\hline Implementability & Not Applicable & $\begin{array}{l}\text { Institutional controls are generally } \\
\text { very easy to implement. The } \\
\text { implementation will require } \\
\text { coordination with all entities at the } \\
\text { site. DOE/NV will record land-use } \\
\text { restrictions as applicable with respect } \\
\text { to administrative closures in the } \\
\text { same manner that the Air Force } \\
\text { presently uses. }\end{array}$ & $\begin{array}{l}\text { An existing, active building, asphalt } \\
\text { pavement, and numerous } \\
\text { underground utilities are present at } \\
\text { the } \mathrm{CAU} \text {. Special consideration will } \\
\text { be required during excavation } \\
\text { activities, and access to the } \\
\text { underlying contaminated soils may } \\
\text { be difficult. }\end{array}$ & $\begin{array}{l}\text { An existing, active building; asphalt } \\
\text { pavement; and numerous } \\
\text { underground utilities are present at } \\
\text { the CAU. These will require special } \\
\text { considerations during drilling } \\
\text { activities. The in situ bioremediation } \\
\text { system is available with off-the-shelf } \\
\text { technology and will remediate soils } \\
\text { even if the soil is located below the } \\
\text { building. }\end{array}$ \\
\hline Cost & Not Applicable & $\$ 3,277^{b}$ & $\$ 401,162$ & $\$ 73,605$ \\
\hline
\end{tabular}

NDEP = Nevada Division of Environmental Protection

ppm $=$ Parts per million

$\mathrm{CAU}=$ Corrective Action Unit

$\mathrm{TPH}=$ Total petroleum hydrocarbons

UST = Underground storage tank

${ }^{\text {a }}$ Nevada Administrative Code, 1996.

Includes emplacement of signs at the $\mathrm{CAU}$ prohibiting intrusive activities.

Nole: Reference to the $100 \mathrm{ppm}$ TPH action level is from NAC 459 
Table 3-2

Detailed Comparison of the Corrective Action Alternatives

(Sheet 1 of 2)

\begin{tabular}{|c|c|c|c|c|}
\hline $\begin{array}{c}\text { Evaluation } \\
\text { Criteria }\end{array}$ & $\begin{array}{l}\text { Alternative } 1 \\
\text { No Action }\end{array}$ & $\begin{array}{c}\text { Alternative } 2 \\
\text { Institutional Control }\end{array}$ & $\begin{array}{c}\text { Alternative } 3 \\
\text { Excavation and Disposal }\end{array}$ & $\begin{array}{c}\text { Alternative 4 } \\
\text { In Situ Bioremediation }\end{array}$ \\
\hline \multicolumn{5}{|c|}{ General Standards } \\
\hline $\begin{array}{l}\text { Overall } \\
\text { Protection of } \\
\text { Human Health } \\
\text { and the } \\
\text { Environment }\end{array}$ & $\begin{array}{l}\text { Alternative } 1 \text { may offer a lesser } \\
\text { degree of protection to human } \\
\text { health and the environment. } \\
\text { TPH-contaminated subsurface } \\
\text { soils remain in place above action } \\
\text { levels, but no migration pathways } \\
\text { exist. Inadvertant intrusion could } \\
\text { result in exposure to } \\
\text { unacceptable contaminant levels }\end{array}$ & $\begin{array}{l}\text { Overall, Alternative } 2 \text { and } 4 \text { are } \\
\text { similarly protective, followed by } \\
\text { Alternative } 3 \text { then Alternative } 1 \text {. } \\
\text { Alternative } 2 \text { prevents intrusion to the } \\
\text { waste while allowing natural biological } \\
\text { activity to reduce contaminant } \\
\text { concentrations. This is similar to } \\
\text { Alternative } 4 \text {, which would result in a } \\
\text { quicker cleanup, but also has some } \\
\text { short- term considerations associated } \\
\text { with implementation. }\end{array}$ & $\begin{array}{l}\text { Alternative } 3 \text { is more effective than } \\
\text { Alternative } 1 \text {, but not as effective as } \\
\text { Alternatives } 2 \text { and } 4 \text {. Some degree of } \\
\text { risk is present for receptors along the } \\
\text { transportation routes and at the disposal } \\
\text { facility. }\end{array}$ & $\begin{array}{l}\text { Alternative } 2 \text { and } 4 \text { offer the highest } \\
\text { degree of overall protection of human } \\
\text { health and the environment. } \\
\text { Bioremediation reduces TPH levels in } \\
\text { the subsurface soils to harmless end } \\
\text { products. No exhaust is anticipated from } \\
\text { the treatment system which would } \\
\text { adversely impact human health or the } \\
\text { environment. Alternative } 4 \text { requires the } \\
\text { installation of wells and a remediation } \\
\text { system; this results in slightly greater } \\
\text { short-term risk and more difficult } \\
\text { implementability than Alternative } 2 \text {. } \\
\text { Alternative } 4 \text { results in a potentially } \\
\text { quicker remediation. }\end{array}$ \\
\hline $\begin{array}{l}\text { Attain Media } \\
\text { Cleanup } \\
\text { Standards }\end{array}$ & $\begin{array}{l}\text { Alternative } 1 \text { may attain media } \\
\text { cleanup standards through } \\
\text { natural processes. }\end{array}$ & $\begin{array}{l}\text { Alternative } 2 \text { may attain media } \\
\text { cleanup standards through natural } \\
\text { processes. }\end{array}$ & \multicolumn{2}{|c|}{ Both Alternatives 3 and 4 attain the media cleanup goal of $100 \mathrm{ppm} \mathrm{TPH.}$} \\
\hline $\begin{array}{l}\text { Control the } \\
\text { Source of the } \\
\text { Release(s) }\end{array}$ & $\begin{array}{l}\text { The source has been removed. } \\
\text { Alternative } 1 \text { does not actively } \\
\text { control the migration of residual } \\
\text { TPH through the vadose zone } \\
\text { (i.e., no treatment of residuals); } \\
\text { however, the distance to } \\
\text { groundwater reduces the } \\
\text { significance of the migration. The } \\
\text { asphalt cover limits infiltration. } \\
\text { Natural processes will likely } \\
\text { reduce concentrations. }\end{array}$ & $\begin{array}{l}\text { The source has been removed. } \\
\text { Alternative } 2 \text { does not actively control } \\
\text { the migration of residual TPH through } \\
\text { the vadose zone (i.e., no treatment of } \\
\text { residuals); however, the distance to } \\
\text { groundwater reduces the significance } \\
\text { of the migration. The asphalt cover } \\
\text { limits infiltration. Natural processes } \\
\text { will likely reduce concentrations. }\end{array}$ & \multicolumn{2}{|c|}{$\begin{array}{l}\text { The source of the release has been removed; however, both Alternatives } 3 \text { and } 4 \\
\text { remediate the residual TPH soil contamination to acceptable levels (i.e., } 100 \mathrm{ppm} \text { ) } \\
\text { through removal or in place treatment. }\end{array}$} \\
\hline $\begin{array}{l}\text { Comply with } \\
\text { Standards for } \\
\text { Management of } \\
\text { Wastes }\end{array}$ & $\begin{array}{l}\text { Alternative } 1 \text { does not generate } \\
\text { waste. }\end{array}$ & Alternative 2 does not generate waste. & $\begin{array}{l}\text { Alternative } 3 \text { will create hydrocarbon- } \\
\text { contaminated waste which must be } \\
\text { disposed of in accordance with } \\
\text { applicable NDEP requirements } \\
\text { (NAC 459.9974). }\end{array}$ & $\begin{array}{l}\text { Creates much less waste than } \\
\text { Alternative } 3 \text { and only investigation- } \\
\text { derived waste which must be disposed } \\
\text { in accordance with applicable NDEP } \\
\text { requirements (NAC 459.9974). }\end{array}$ \\
\hline
\end{tabular}


Table 3-2

Detailed Comparison of the Corrective Action Alternatives (Sheet 2 of 2)

\begin{tabular}{|c|c|c|c|c|}
\hline $\begin{array}{l}\text { Evaluation } \\
\text { Criteria }\end{array}$ & $\begin{array}{l}\text { Alternative } 1 \\
\text { No Action }\end{array}$ & $\begin{array}{c}\text { Alternative } 2 \\
\text { Institutional Control }\end{array}$ & $\begin{array}{l}\text { Alternative } 3 \\
\text { Excavation and Disposal }\end{array}$ & $\begin{array}{c}\text { Alternative } 4 \\
\text { In Situ Bloremediation }\end{array}$ \\
\hline \multicolumn{5}{|c|}{ Selection Decision Factors } \\
\hline $\begin{array}{l}\text { Short-Term } \\
\text { Reliability and } \\
\text { Effectiveness }\end{array}$ & Not Applicable & $\begin{array}{l}\text { Alternative } 2 \text { is the most effective } \\
\text { because no workers are exposed to } \\
\text { the waste and no construction } \\
\text { activities are required. }\end{array}$ & $\begin{array}{l}\text { More effective than Alternative } 1 . \\
\text { Corrective action objectives and cleanup } \\
\text { goals are achieved immediately } \\
\text { following excavation of the } \\
\text { TPH-contaminated soils to acceptable } \\
\text { levels. Construction activities and } \\
\text { worker exposure are greatest for this } \\
\text { alternative. }\end{array}$ & $\begin{array}{l}\text { More effective than Alternatives } 1 \text { and } 3 \text {, } \\
\text { but slightly less effective than Alternative } \\
\text { 2. Corrective action objectives and } \\
\text { cleanup goals are not achieved until the } \\
\text { completion of the in situ bioremediation } \\
\text { process (approximately two years). } \\
\text { Installation of wells results in some } \\
\text { worker exposure to waste and } \\
\text { construction activities are required. }\end{array}$ \\
\hline $\begin{array}{l}\text { Reduction of } \\
\text { Toxicity, Mobility, } \\
\text { and/or Volume }\end{array}$ & Not Applicable & $\begin{array}{l}\text { Reduction only through natural } \\
\text { processes }\end{array}$ & $\begin{array}{l}\text { Alternative } 3 \text { reduces the mobility by } \\
\text { disposing in a safer condition. However, } \\
\text { the toxicity and volume are only reduced } \\
\text { through natural processes. The } \\
\text { relocation of the soils may impact the } \\
\text { favorable conditions for natural } \\
\text { processes. }\end{array}$ & $\begin{array}{l}\text { Alternative } 4 \text { is the most effective in } \\
\text { reducing the toxicity, mobility, and } \\
\text { volume because the waste is actually } \\
\text { converted to harmless by-products in a } \\
\text { short period of time. The other } \\
\text { alternatives have similar reduction } \\
\text { through time from natural processes, but } \\
\text { the enhancement of these processes in } \\
\text { Alternative } 4 \text { should speed the reduction. }\end{array}$ \\
\hline $\begin{array}{l}\text { Long-Term } \\
\text { Reliability and } \\
\text { Effectiveness }\end{array}$ & Not Applicable & $\begin{array}{l}\text { Alternative } 2 \text { offers slightly lower } \\
\text { long-term reliability because the } \\
\text { controls must be in place indefinitely. } \\
\text { All three alternatives are reliable and } \\
\text { effective in the long term. }\end{array}$ & \multicolumn{2}{|c|}{$\begin{array}{l}\text { Alternatives } 3 \text { and } 4 \text { offer similar degrees of effectiveness in achieving corrective } \\
\text { action objectives and cleanup goals. }\end{array}$} \\
\hline Implementability & Not Applicable & $\begin{array}{l}\text { Alternative } 2 \text { offers the highest level of } \\
\text { implementability because mainly only } \\
\text { administrative processes are required. } \\
\text { Some signs may need to be installed. }\end{array}$ & $\begin{array}{l}\text { Alternative } 3 \text { offers the lowest level of } \\
\text { implementability. Even though } \\
\text { excavation is a proven remedial } \\
\text { technology, the underground utilities and } \\
\text { the fact that the building is still actively } \\
\text { used may make excavation difficult. }\end{array}$ & $\begin{array}{l}\text { Alternative } 4 \text { offers a higher level of } \\
\text { implementability than Alternative } 3 \text { since } \\
\text { complexities associated with excavation } \\
\text { activities are reduced through drilling } \\
\text { and installation of only two shallow in } \\
\text { situ bioremediation wells. }\end{array}$ \\
\hline Cost & Not Applicable & $\$ 3,277$ & $\$ 401,162$ & $\$ 73,605$ \\
\hline
\end{tabular}

TPH = Total petroleum hydrocarbons

NDEP = Nevada Division of Environmental Protection

CAS $=$ Corrective Action Site

ppm = Parts per million

$\mathrm{CAU}=$ Corrective Action Unit

Note: Reference to the $100 \mathrm{ppm}$ TPH action level is from NAC 459 


\subsection{Recommended Alternative}

Based on the results of the detailed and comparative analysis of the identified corrective action alternatives presented in this document, the preferred corrective action alternative selected for implementation at the Second Gas Station CAS is Alternative 2, Institutional Controls. Alternative 2 was chosen as the preferred alternative for the following reasons:

- It minimizes health risks by preventing public and worker access to the contaminated soils.

- It complies with standards for management of wastes because no wastes are generated.

- It implements easily with no disturbance of subsurface utilities.

- It provides the most cost-effective protection. Alternative 2 provides a significant cost savings to DOE over Alternatives 3 and 4.

The preferred corrective action alternative was evaluated on its technical merits with focus on performance, reliability, implementability, and safety. The alternative was judged to meet the corrective action objective and to be the most cost-effective closure option. The alternative is also protective of the groundwater as discussed in the following analysis of NAC 459.9973 .1 (a) through (k) criteria:

(a) The depth of groundwater is 110 to $120 \mathrm{~m}$ (360 to $390 \mathrm{ft})(\mathrm{DOE} / \mathrm{NV}, 1996 \mathrm{~b})$. Because the tanks have been removed, a source no longer exists to contribute to plume size or migration. The precipitation for the area (13 to $15 \mathrm{~cm}$ [5 to 6 in.] annually) (DOE/NV1996b) does not significantly influence the movement of the contaminants. The parameters are favorable for natural attenuation of the hydrocarbons through biological degradation. While the contaminants may continue to migrate vertically, the rate will be slow without a driving force and the contaminants will continue to degrade over time.

(b) The distance to the nearest drinking water well (Sandia 6) is $650 \mathrm{~m}(2,130 \mathrm{ft}$ ) northeast of the CAS. Groundwater in this area moves generally to the northwest (DOE/NV, 1996b). The areal extent of the contamination as determined in the site investigation is very limited with the plume currently approximately $13 \mathrm{~m}(50 \mathrm{ft})$ wide (see Figure A.3-2 in Appendix A); therefore, for the contaminants to affect 
the drinking water well, they will need to travel the vertical distance to the groundwater, then travel through the groundwater in a direction different from normal groundwater flow to the radius of influence of the well. Because the plume has migrated only a short vertical distance and has had no appreciable lateral migration over the last 25 to 35 years and because the hydrocarbons are naturally degrading with time, the likelihood of any impacts to the well is minimal.

(c) The soil consists of sandy gravels and gravels with variable percentages of silts and clays. The porosity measured in the investigation is $36.8 \%$, but will be variable; any silt or clay layers will only serve to impede migration of the contaminants. The higher the content of silts and clays, the higher the soil retention capability for the contaminants and the smaller the vertical distance the hydrocarbons will travel before they are transformed to residual contamination (Dragun, 1988).

(d) Annual precipitation averages 13 to $15 \mathrm{~cm}$ (5 to 6 inches [in.]). Annual evaporation is between 147 and $168 \mathrm{~cm}$ (58 and $66 \mathrm{in}$.) (DOE/NV 1996b). The high evaporation and low precipitation create a negative water balance for the area; therefore, no driving force associated with precipitation is available to mobilize contaminants to groundwater.

(e) The type of regulated substance released is petroleum hydrocarbons in the form of diesel fuel. Light, bulk hydrocarbons, such as diesel, can migrate downward in unsaturated zone soils due to gravity and capillary forces. The downward migration is influenced by the following parameters:

- Amount of hydrocarbons transformed into residual saturation

- Presence of an impermeable bed.

- Natural degradation of the hydrocarbons

Because of the large distance to groundwater, the slow travel time associated with the gravity drainage mechanism for migration, the small size of the plume, and the biologically favorable environment, the contaminants will not likely reach or impact the groundwater.

Diesel components vary widely among manufacturers. Without specific chemical analysis of the components of the hydrocarbon contamination at the CAU, a 
quantitative estimate of the risk is not possible. Components within diesel are known carcinogens. However, pathways to the contaminants do not currently exist. The only potential pathway would be inadvertent intrusion to the waste. Alternative 2 controls this intrusion administratively.

The highest concentration detected in the investigation was $12,000 \mathrm{ppm}$. The sample associated with this concentration was collected from boring SB-5 at a depth of $6.7 \mathrm{~m}(22 \mathrm{ft})$. This same boring had a concentration of $11,000 \mathrm{ppm}$ at $3.7 \mathrm{~m}(12 \mathrm{ft}$ ). These were the only two hits out of 41 samples (not including quality assurance samples) that exceeded the $10,000 \mathrm{ppm}$ trigger level for hydrocarbons. Only seven of the 41 samples collected had TPH concentrations above 100 ppm (Appendix A).

(f) The extent of contamination is limited to an area of $13 \mathrm{~m}$ by $6 \mathrm{~m}$ ( $42 \mathrm{ft}$ by $20 \mathrm{ft}$ ) laterally and to a depth of $11 \mathrm{~m}(35 \mathrm{ft})$. The movement of the plume laterally and vertically is slowed significantly because the source has been removed. Natural biological degradation of the TPH will further limit the potential for contaminants to reach groundwater.

(g) Presently, the CAS is located in a government-controlled facility with the potential, future land use of livestock grazing. The TTR is a restricted area that is guarded on a 24-hr, 365-day-per-year basis; unauthorized personnel are not admitted to the facility. The CAU is currently covered by a combination of asphalt and gravel, preventing access to the high concentrations of contaminants, which are located $3.7 \mathrm{~m}(12 \mathrm{ft})$ below the surface. The preferred alternative will control intrusion to the contaminated zone.

(h) Preferred routes of migration are extremely limited or nonexistent since the point sources of the hydrocarbons have been removed and the surface area is covered by asphalt, gravel, and buildings. Inadvertent intrusion is the only pathway from the contaminants to potential receptors. This intrusion would be controlled administratively in addition to the current physical barriers.

(i) The subsurface hydrocarbons are located beneath an asphalt parking lot and an adjacent building (Building 03-60). Numerous buried utilities cross this area. 
(j) The potential for a hazard related to fire, vapor, or explosion is very low because the TPH is located subsurface under several feet of soil. The fire and explosion potential for diesel is moderate when exposed to fire or flame, neither of which are applicable to the buried contaminants at the CAU.

(k) No other site-specific factors are known at this time.

The preferred alternative will require coordination with the U.S. Air Force. DOE/NV will record land-use restrictions, as applicable, with respect to administrative closures in the same manner that the U.S. Air Force presently uses.

Based on the evaluation in this CADD, administrative closure is the preferred closure method for the Second Gas Station. 


\subsection{References}

CFR, see Code of Federal Regulations.

Code of Federal Regulations. 1996. Title 40 CFR, Parts 258 - 271. Washington, DC:

U.S. Government Printing Office.

DOE, see U.S. Department of Energy.

Dragun, James. 1988. The Soil Chemistry of Hazardous Materials. Silver Springs, MD: Hazardous Materials Control Research Institute.

EPA, see U.S. Environmental Protection Agency.

FFACO, see Federal Facility Agreement and Consent Order.

Federal Facility Agreement and Consent Order of 1996. 1996. Agreed to by the Nevada Division of Environmental Protection, the U.S. Department of Energy, and the U.S. Department of Defense.

NAC, see Nevada Administrative Code.

Nevada Administrative Code. 1990. NAC 534.421, "Plugging: Wells Drilled for Purposes Other Than As Water Wells." Carson City, NV.

Nevada Administrative Code. 1996. NAC 459, "Hazardous Materials." Carson City, NV.

U.S. Department of Energy, Nevada Operations Office. 1992. Tonopah Test Range Tour, 28 April. Las Vegas, NV

U.S. Department of Energy, Nevada Operations Office. 1996a. Corrective Action Investigation Plan: Second Gas Station Underground Storage Tanks, Tonopah Test Range, Rev. 1. Las Vegas, NV: IT Corporation.

U.S. Department of Energy, Nevada Operations Office. 1996b. Corrective Action Unit Work Plan for the Tonopah Test Range, DOE/NV-426. Las Vegas, NV: IT Corporation.

U.S. Department of Energy, Nevada Operations Office. 1996c. Industrial Sites Quality Assurance Project Plan, DOE/NV-425. Las Vegas, NV: IT Corporation.

U.S. Environmental Protection Agency, Office of Research and Development. 1991. Guidance on Resource Conservation and Recovery Act (RCRA) Corrective Action Decision Documents, EPA/540/G-91/011. Washington, DC: U.S. Government Printing Office. 
U.S. Environmental Protection Agency, Office of Solid Waste and Emergency Response. 1994. Final Resource Conservation and Recovery Act (RCRA) Corrective Action Plan, EPA 520-R-94-004. Washington, DC: U.S. Government Printing Office. 


\section{Appendix A}

\section{Second Gas Station Investigation Report Corrective Action Unit No. 403, Tonopah Test Range}




\section{A.1.0 Introduction}

This investigation report represents implementation of the Corrective Action Investigation Plan (CAIP) (DOE/NV, 1996a) for Corrective Action Unit (CAU) No. 403 in accordance with the Federal Facility Agreement and Consent Order (FFACO, 1996), the CAU Work Plan for the Tonopah Test Range (TTR) (DOE/NV, 1996b), and the Industrial Sites Quality Assurance Project Plan (QAPP) (DOE/NV, 1996c). Corrective Action Unit No. 403, consisting of Corrective Action Site (CAS) No. 03-02-004-0360, is the former location of a refueling station now called the Second Gas Station. The CAS is located at Area 3 on the TTR (Figures A.1-1 and A.1-2), which is part of the Nellis Air Force Range in Nye County, Nevada. The TTR is operated by the U.S. Department of Energy (DOE) and the U.S. Department of Defense (DoD).

Since the issuance and implementation of the Second Gas Station CAIP, the initial subsurface investigation, and the issuance of Revision No. 1 of this investigation report, new information has been discovered that shows the Underground Storage Tanks (UST) were configured differently than they were portrayed in the CAIP. Due to this new information, an additional subsurface boring was drilled to complete the subsurface investigation. Figure A.1-3 depicts the tank configurations used in the original investigation. Figure A.1-4 depicts the tank configurations used in the subsequent investigation based on the new information.

\section{A.1.1 Project Objective}

The objectives of this project were threefold:

- Collect data to confirm the presence or absence of contamination.

- Determine the lateral and vertical extent of any contaminants.

- Provide sufficient information to develop closure strategies for the sites. 


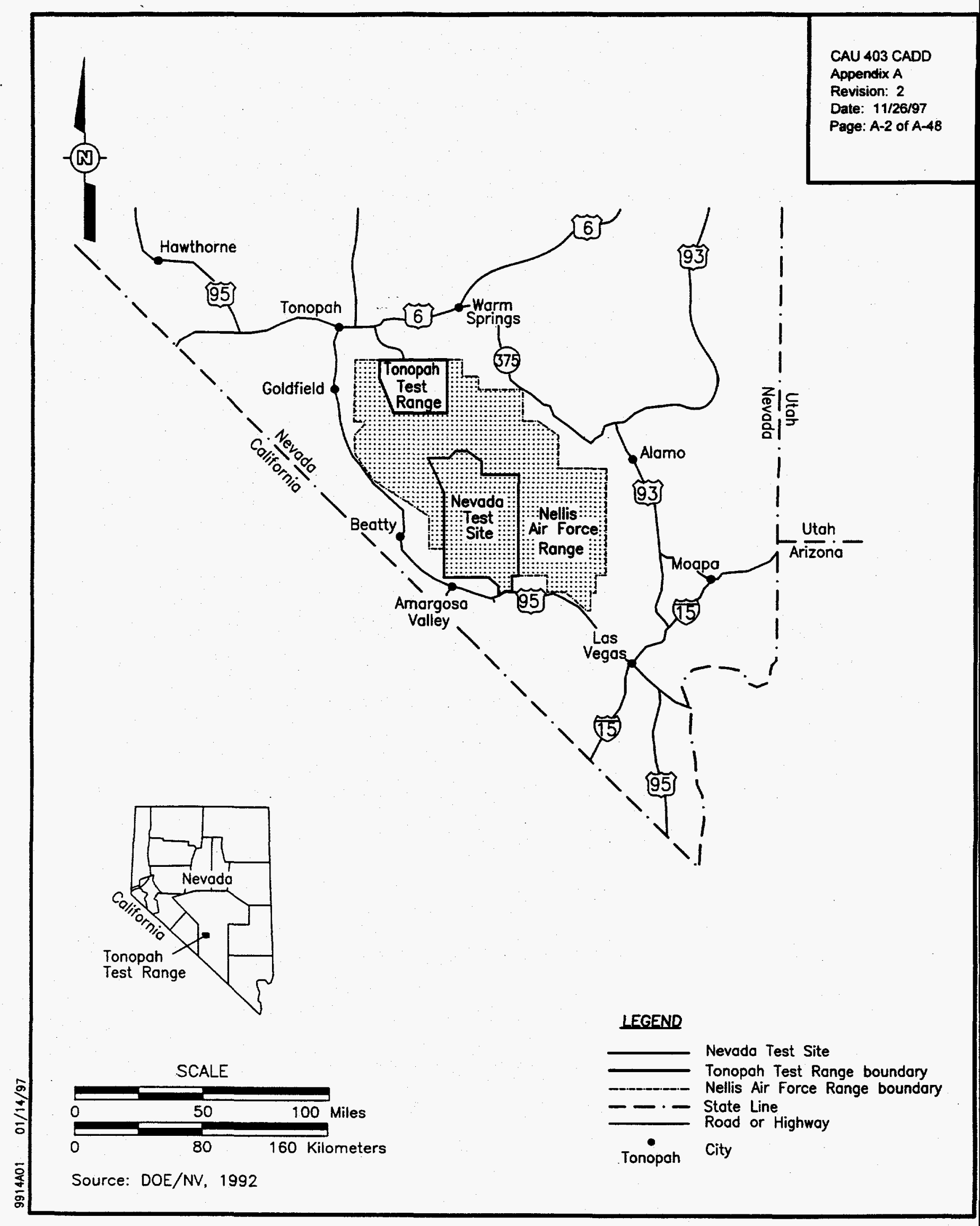

Figure A.1-1

Tonopah Test Range Location Map 


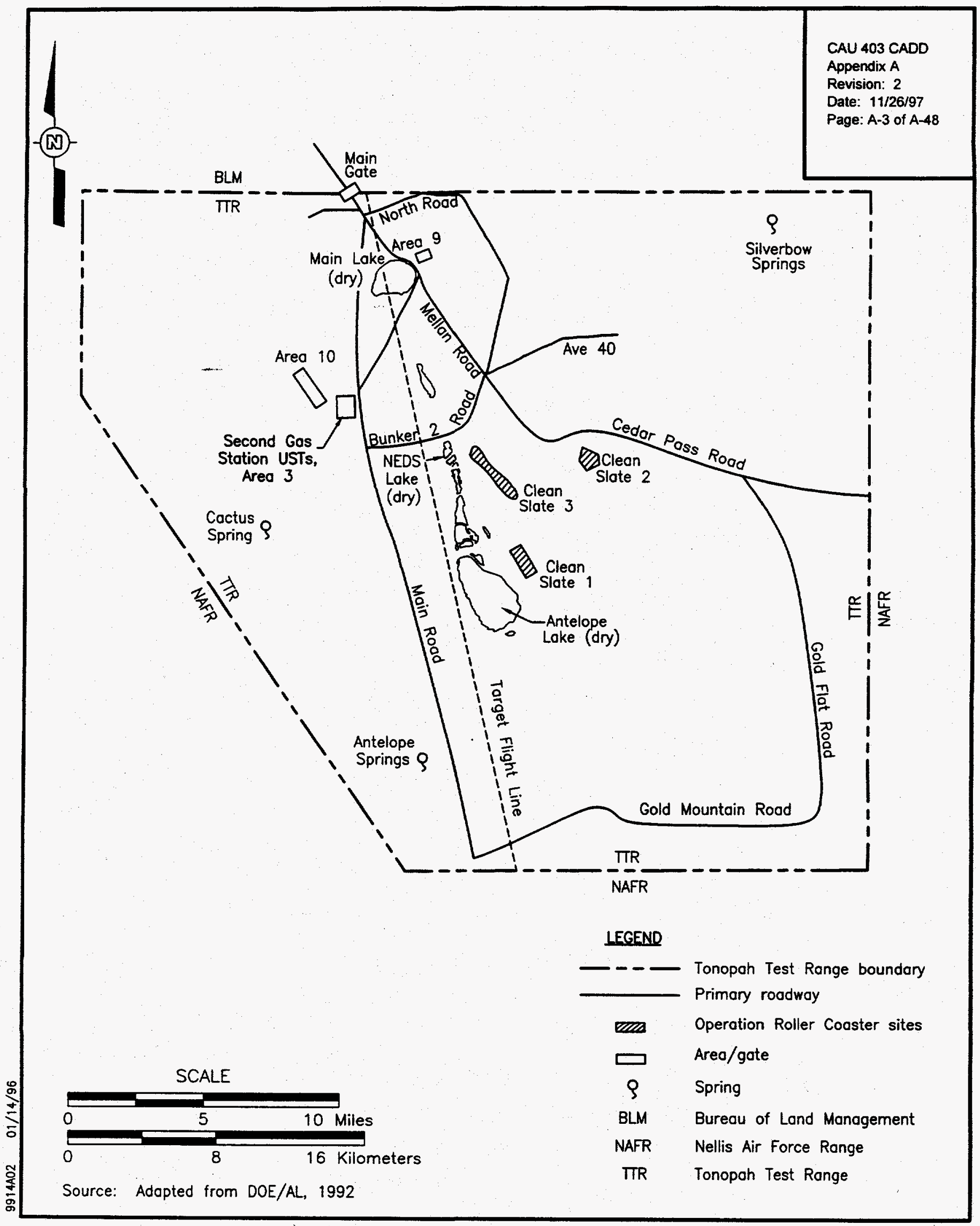

Figure A.1-2

Location of the Second Gas Station, Area 3, Tonopah Test Range 


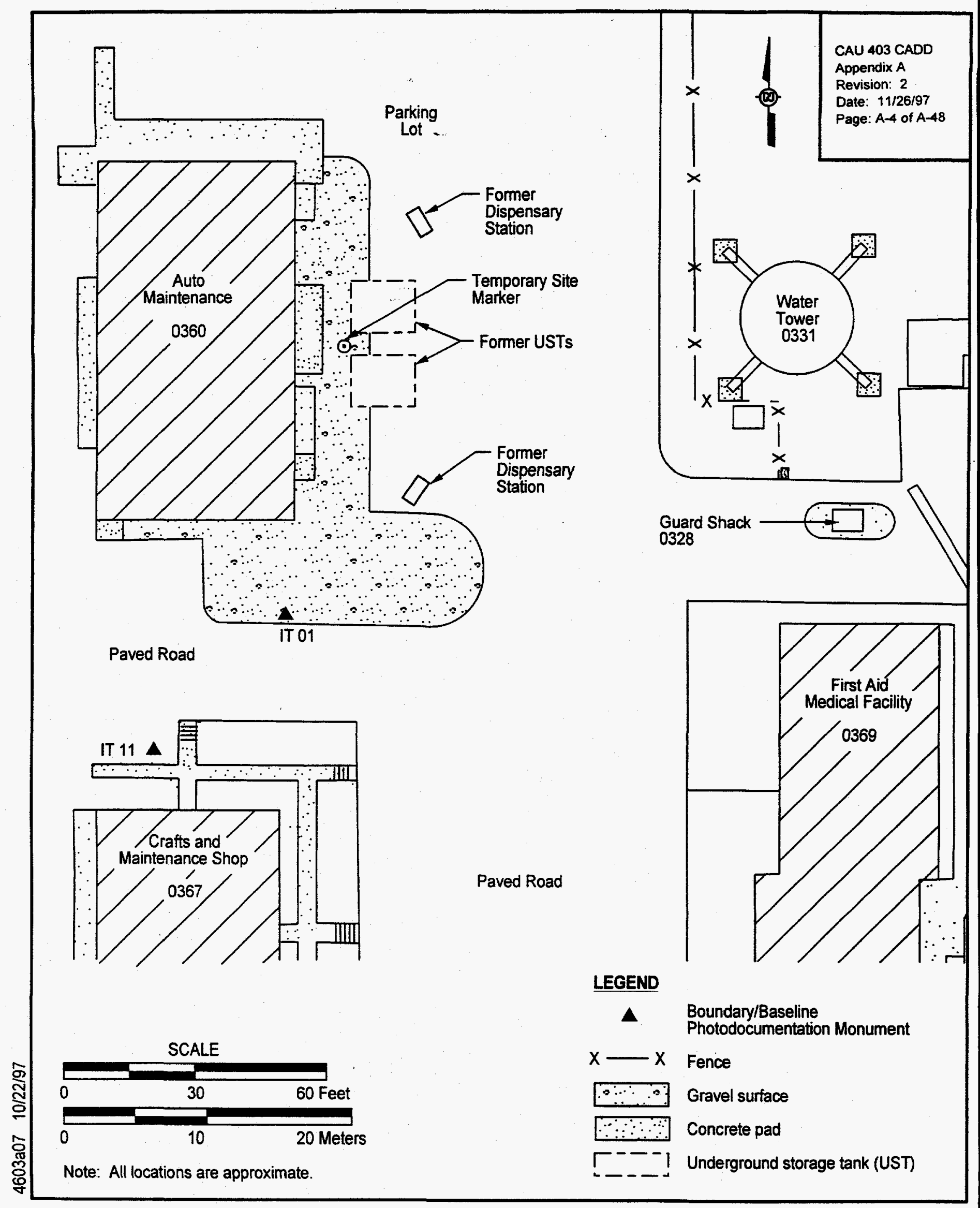

Figure A.1-3

Original Site Map, Second Gas Station and Surrounding Facilities, Area 3, 


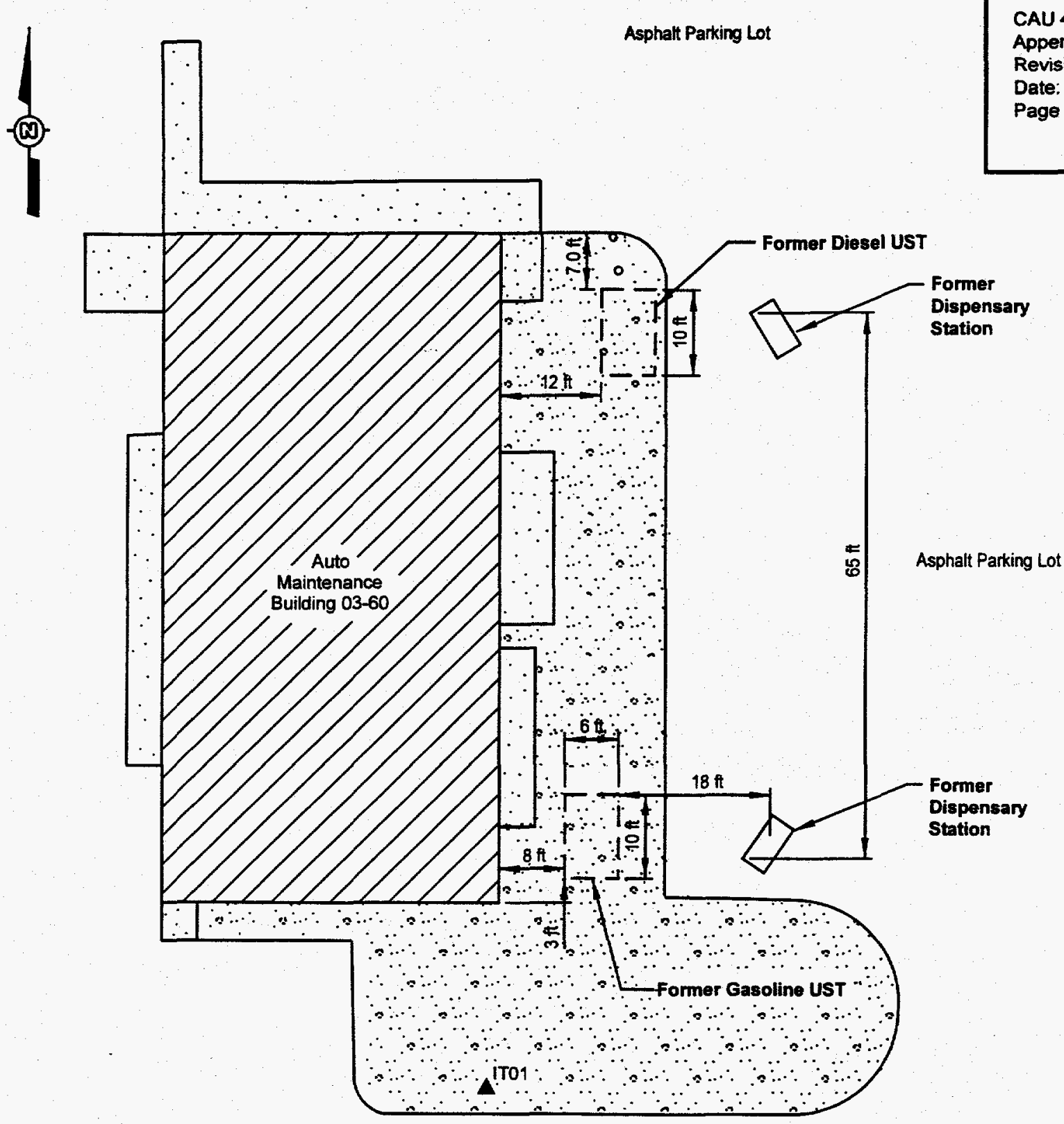

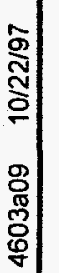

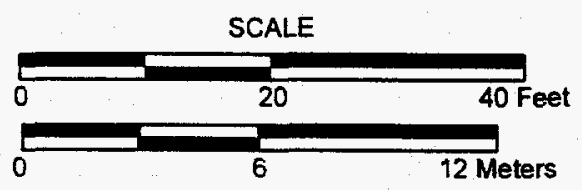

Note: All locations are approximate.

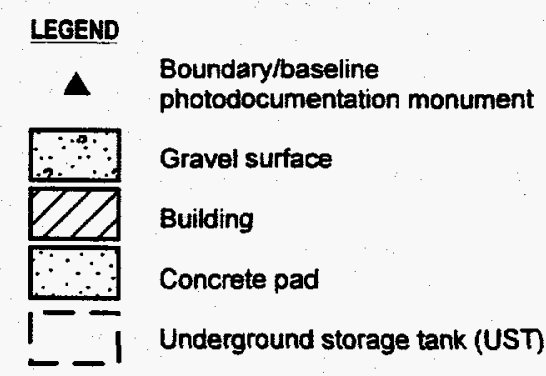

Figure A.1-4

Current Site Map, Second Gas Station and Surrounding Facilities, Area 3, Tonopah Test Range 
To meet the objectives, thirteen boreholes were drilled and sampled to:

- Evaluate the condition of the subsurface sediment and determine if any contaminants of concern (COCs) were present.

- Assess the potential for migration of potential COCs downward from potential source points through the surrounding sediment.

- Estimate the lateral extent of contaminant migration (if present) from the previous locations of the tank and dispensary stations.

Forty-six subsurface samples were collected from thirteen soil borings for analysis of potential COCs. The subsurface samples were selected from sample sets that were collected at 3-meter $(\mathrm{m})$ (10-foot [ft]) intervals to a maximum of $25 \mathrm{~m}(82 \mathrm{ft}$ ) below ground surface (bgs). Detailed field observation of the surface and subsurface conditions, including lithologic description of soil boring cuttings, was also made during the investigation activities. Additionally, geotechnical samples were collected to establish porosity, permeability, and microbe and nutrient levels within the soils.

\section{A.1.1.1 Report Content}

This investigation report is divided into four parts:

- Section A.1.0 - Introduction

- Section A.2.0 - Field investigation and sampling activities, a description of the site and sampling methodology

- Section A.3.0 - Sample analysis, a discussion of the laboratory analytical results

- Section A.4.0 - Quality assurance, in which the precision, accuracy, representativeness, completeness, and comparability of the sample results are described

To make this investigation report more concise, the following field documentation and laboratory data were not included; however, they are available in the IT Corporation (IT) project files and will be available upon request:

- Field Activity Daily Logs

- Sample Collection Logs 
- Analysis Requests/Chain-of-Custody forms

- Soil sample descriptions

- Laboratory certificates of analysis

- Headspace and Petroflag ${ }^{\text {TM }}$ hydrocarbon screening results

- Surveillance results

Additional descriptions of the site history, waste inventories, and spill information are discussed in the CAIP (DOE/NV, 1996a) for this.CAU.

\section{A.1.1.2 Summary of Findings in Accordance with NAC 459.9973}

Soils at the Second Gas Station CAS exceeded soil actions levels established by the State of Nevada. In part, this investigation determined and assessed the site information as specified in the Nevada Administrative Code (NAC) 459.9973.1, (a) through (k), and the CAIP (DOE/NV, 1996a). The information corresponding to Sections (a) through $(k)$ is listed in the following text:

(a) The depth to groundwater is 110 to $120 \mathrm{~m}$ (360 to $390 \mathrm{ft}$ ).

(b) The distance to the nearest drinking water well (Sandia 6) is $650 \mathrm{~m}(2,130 \mathrm{ft}$ ) northeast of the CAS.

(c) The soil consists of sandy gravels and gravels with variable percentages of silts and clays.

(d) Annual precipitation averages 13 to 15 centimeters $(\mathrm{cm})$ (5 to 6 inches [in.]).

(e) The type of regulated substance released is petroleum hydrocarbons in the form of diesel fuel.

(f) The extent of contamination is limited to an area of $13 \mathrm{~m}$ by $6 \mathrm{~m}(42 \mathrm{ft}$ by $20 \mathrm{ft}$ ) laterally, to a depth of $11 \mathrm{~m}(35 \mathrm{ft})$.

(g) Presently, the CAS is part of an active military facility with the potential, future land use (pending closure of the government facility) of livestock grazing.

(h) Potential routes of migration are extremely limited or nonexistent as the point sources of the hydrocarbons are removed, and the surface area is covered by asphalt and buildings.

(i) The subsurface hydrocarbons are located beneath an asphalt parking lot and an adjacent building (Building 03-60). Numerous buried utilities cross this area. 
(j) The potential for a hazard related to fire, vapor, or explosion is very low.

(k) No other site-specific factors are known at this time. 


\section{A.2.0 Field Investigation and Sampling Activities}

Field activities were performed by IT from August 20 to September 26, 1996, and from September 22 to September 25, 1997. Samples were collected and documented by following established sampling procedures, field activity documentation (IT, 1996a), sample collection documentation, decontamination, chain of custody, shipping, and radiation screening protocols (IT, 1994). Field activities were performed in accordance with field sampling instructions as prescribed in the CAIP (DOE/NV, 1996a) and an approved Site-Specific Health and Safety Plan (IT, 1996b). Quality control (QC) samples (e.g., field blanks, equipment blanks, trip blanks, and sample duplicates) were collected, as required, by the Industrial Sites Quality Assurance Project Plan (DOE/NV, 1996c) and approved contractor procedures (IT, 1994). All field and sample documentation is maintained in IT project files. During the field activities, waste minimization practices were followed, including segregation of personal protective equipment into bags (based upon daily use) and collection and segregation of the rinsate waters from decontamination operations.

\section{A.2.1 Site Description and Conditions}

The Second Gas Station CAS is located between the Area 3 compound and Building 03-60 (Figure A.1-3). Presently the site is used as a parking area. Building 03-60 is currently used for mechanical repairs, and the Area 3 compound is a secured area with limited access.

The surface locations of boreholes were over both asphalt and gravel. Numerous underground utilities were indicated on as-built diagrams, utility maps, and by Kirk-Mayer Incorporated personnel familiar with the area. To avoid damaging these utilities during drilling, an air knife digging tool was used to excavate and visually check the first several feet prior to the use of the drill rig and auger. On two occasions, buried utilities were encountered, but not damaged. In these cases, new boring locations were selected by the site supervisor and visually checked again for buried utilities.

Topography in the vicinity of the site is nearly level with a slight grade draining to the west. No overhead hazards exist in the area. Work at the site did not pose a traffic hazard. 


\section{A.2.2 Soil Sampling Logistics}

This section describes the boring locations and the subsurface soil sampling for the Second Gas Station CAS.

\section{A.2.2.1 Boring Locations}

Thirteen borings were required to complete the investigation of the Second Gas Station CAS. Initially, five soil borings, designated SB-1 through 5, were planned at the originally approximated locations of the dispensary stations and USTs. Soil borings SB-1 and SB- 5 were located at the south and north dispensary locations, respectively. SB-2, SB-3B, and SB-4 were located on the south UST, between the tanks, and on the north UST, respectively. If any COCs were detected in the initial boreholes by field screening, then additional borings, called step-outs (SO), were drilled. In the event underground utilities were encountered at a proposed location, then an alphabetical designation would follow the soil boring number (i.e., SB-3B or SO-3B).

The COCs were detected by field screening in SB-4 and SB-5, and step-out borings SO-1 through SO-7 were drilled to determine the lateral and vertical extent of the subsurface COCs.

Based on the new tank location information, SB-6 was located over the modified former gasoline UST location. Step-outs were not necessary for SB-6. Adequate subsurface data for the modified former diesel UST location were recovered from boring SO-3B.

Initially, borings were drilled to a minimum of $7 \mathrm{~m}(20 \mathrm{ft}) \mathrm{bgs}$ plus an additional, two non-detect

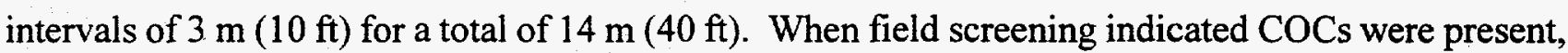
the boreholes were advanced until field screening indicated two non-detects in a row. In the event a $\mathrm{COC}$ was found at a depth that exceeded the depths of borings already drilled, then those borings were deepened and sampled to the depth of the borehole where the COCs were detected.

Once a borehole reached a minimum required depth, the samples collected to that point were field-screened with a kit that detects hydrocarbons. If the presence of contaminants was not indicated, then two confirmatory "clean" samples (the last two samples collected) and a "dirty" sample (from a zone most likely affected) were collected. If COCs were indicated, drilling and 
screening continued until two confirmatory "clean" samples were collected and packaged for shipment to an off-site laboratory. The most contaminated sample was collected and packaged for shipment to an off-site laboratory.

Samples (including bioassay and geotechnical samples) were assigned unique alphanumeric sample numbers which were designated sequentially as they were collected (i.e., TTR00160, TTR00161, etc.).

\section{A.2.2.2 Subsurface Sampling}

Subsurface samples were collected at 3-m (10-ft) intervals using a 9-cm (3.5-in.) hollow stem auger with a 6.5-cm (2.5-in.) California Modified split-spoon with brass sleeves. In most cases, the samples were collected directly within the brass sleeves that lined the sampler to minimize sample volatilization. Each sample was screened for hydrocarbons using a photo ionization detector and the Petroflag ${ }^{\text {TM }}$ field screening kit. On-site screening was used to select samples for off-site analysis.

Typical sample collection occurred as follows: A sampling team member decontaminated and assembled the split-spoon sampler. When the driller reached the sampling depth, the split-spoon sampler was attached to the 140-pound drive hammer by the sample team member; then the driller ran the split-spoon sampler to the sample depth. The split-spoon sampler was driven by the driller with a 140-pound hammer and 31-in. drop to collect the sample. The number of hammer blows required to drive the split-spoon sampler down every 6 in. was recorded. Generally, fifty blows for less than 6 in. was considered resistance; although in some cases, additional blows were specified to maximize sample recovery. The time of sample collection was noted at the time the sampler was driven to its limit. Finally, the driller drilled over the sampler to free it from the surrounding formation and brought the sampler to the surface.

Once at the surface, a sampling team member took the split-spoon sampler off the hammer and loosened the shoe (the cutting edge of the sampler) and hammer sub (the device that attaches the sampler to the drilling assembly). Then, the split-spoon sample was carried to the sampling table located inside a van. The split-spoon sampler was then disassembled to expose the (6-in.) brass sleeves. The sleeves were collected in the order of deepest towards the shallowest. The ends of each 
brass sleeve were sealed with Teflon ${ }^{\mathrm{TM}}$ sheets and plastic caps. Each cap was annotated with the date, time, and depth of sample collection as well as the vertical orientation. The deepest brass sleeve was collected for Total Petroleum Hydrocarbons (TPH) as gasoline and diesel and Toxicity Characteristic (TC) lead. The second sleeve was collected for Petroflag ${ }^{\mathrm{TM}}$ screening. Material remaining in the shoe of the split-spoon sampler was then collected for headspace and sample description.

In the event a sleeve was not full or a potential for headspace occurred in the sleeve, the sample was transferred to sample jars.

Samples were immediately placed on ice until Petroflag ${ }^{\mathrm{TM}}$ screening for hydrocarbons was completed. Based upon the screening results, the most highly impacted sample from each borehole was selected for laboratory analysis, along with two confirmatory clean samples from the last $20 \mathrm{ft}$ drilled. Even if all samples in a given borehole were non-detect (i.e., $<100$ parts per million [ppm] based on Petroflag ${ }^{\mathrm{TM}}$ results), two confirmatory clean samples from the last $20 \mathrm{ft}$ drilled were selected for shipment to the off-site lab. The samples were then assigned sample numbers, labeled, custody-taped, and bagged for shipment to the IT Las Vegas office. At the IT Las Vegas office, the samples were repacked for Federal Express shipment to Quanterra Environmental Services in Earth City, Missouri.

\section{A.2.2.3 Petroflag ${ }^{\mathrm{TM}}$ Screening}

All samples collected at the Second Gas Station CAS were screened for petroleum hydrocarbons using the Petroflag ${ }^{\mathrm{TM}}$ turbimetric analyzer manufactured by the Dexsil Corporation. Petroflag ${ }^{\mathrm{TM}}$ screening was run in batches once the minimum required borehole depth was reached. PetroflagTM methodology uses a solvent to extract any potential hydrocarbons from the soil. The extract is then filtered into a developer and allowed to develop for 10 to 15 minutes. If hydrocarbons are present, the developer clouds. The amount of hydrocarbons present (reported in parts per million) is determined using an optical analyzer that correlates the optical response value to a preselected response factor in the instrument. A response factor for diesel hydrocarbons was selected because it minimized the possibility of false positives which occur when analyzing for gasoline in the presence of diesel. 
At the beginning of each sampling day, a calibration standard was processed and run through the analyzer. Additional calibrations were run if the daily temperature varied greater than 10 degrees Celsius.

Results from the Petroflag ${ }^{\mathrm{TM}}$ screening did not quantitatively match the results from laboratory analysis variables such as temperatures contaminant degradation, and target-specific method difference generally caused Petroflag ${ }^{\mathrm{TM}}$ to give higher values than what the lab would report. However, the Petroflag ${ }^{\mathrm{TM}}$ screening method was an excellent qualitative indicator for the presence of hydrocarbons.

\section{A.2.2.4 Geologic Analysis}

As samples were collected, the following soil characteristics were noted: sand and gravel content, relative amounts of pebbles and cobbles, the absence or presence of clays, and any unusual variations. This information was recorded in field notes and soil boring logs (Attachment 1) for the project. During drilling, soil cuttings were also monitored for staining, odors, and gross lithologic changes.

\section{A.2.2.5 Drilling Characteristics}

Near-surface materials at the Second Gas Station CAS varied from construction-type fill, which included cement blocks to less compacted sandy gravels, to an approximate depth of $5 \mathrm{~m}$ ( $15 \mathrm{ft})$ bgs. Below $5 \mathrm{~m}(15 \mathrm{ft})$, the difficulty of drilling generally increased, often requiring high torque and high bit weight to advance the augers. Sample collection often required high blow counts, 40 to 50 per every 6 inches. Occasionally, the friction of drilling significantly heated the sampler.

Two drilling companies, Converse Consultants Southwest and Spectrum Exploration, were used to complete this investigation. The former began the job with a BK-81 drill rig and drilled three boreholes before equipment failure forced them to relinquish the drilling contract to Spectrum Exploration. Spectrum completed the job using a CME-75 drill rig.

Both drill rigs had difficulty advancing the augers. The drilling required extremely high torque and excessive stress to the drilling equipment. According to the driller from Converse Consultants, the drilling difficulty encountered at the Second Gas Station CAS was nearly identical to what was 
encountered in boreholes they drilled $91 \mathrm{~m}(300 \mathrm{ft})$ to the southeast of the site (Converse, 1994). Alternative methods for further drilling should be considered.

\section{A.2.2.6 Subsurface Stratigraphy}

Soil boring logs and descriptions can be found in Attachment A of this report.

Much of the stratigraphy encountered was medium to very coarse sands with gravels and occasional cobbles. The predominant lithology of the pebbles and cobbles was volcanics. Clay content varied from low to moderate throughout the wells. Samples were usually well-compacted and visually showed a low to moderate moisture content. Drilling hard streaks were commonly encountered at 8 $\mathrm{m}$ to $11 \mathrm{~m}(25 \mathrm{ft}$ to $35 \mathrm{ft})$ and at $15 \mathrm{ft}$ to $18 \mathrm{~m}(50 \mathrm{~m}$ to $60 \mathrm{ft}) \mathrm{bgs}$.

\section{A.2.3 Management of Investigation-Derived Waste}

Investigation-Derived Waste is being managed in accordance with applicable DOE Orders and U.S. Department of Transportation (DOT) and Resource Conservation and Recovery Act (RCRA) regulations. The spent reagents generated from the use of a field-screening kit are being managed as a RCRA hazardous waste, and the EPA code F003 was applied. The reagent waste was placed in a DOT-compliant drum (49 CFR 172 [CFR, 1997]) which was fitted with a Tamper Indicating Device (TID). The reagent waste was compatible with the drum specifications in accordance with the requirements of 40 CFR 265.172 and with Subpart CC of Part 265 (CFR, 1996). The drum was handled and inspected in accordance with the requirements of 40 CFR 265.173 and 174, respectively.

The remaining IDW was handled in accordance with the previously stated requirements. Upon receipt of analytical results from the sampling event the IDW was determined to be a sanitary waste. Each of the waste streams will be sent to a qualified facility for disposal. 


\section{A.3.0 Sample Analysis}

The analytical results from the soil borings at the Second Gas Station CAS have been compiled and analyzed to determine the presence and/or extent of contamination. The analytical results are summarized in the following sections. The complete laboratory result data packages are available in IT project files. Section A.4.0 of this report presents a discussion and summary of quality control samples.

During the drilling and sampling activities, a total of 60 hydrocarbon characterization, geotechnical, and QC samples were collected for analysis. A list of the investigation and geotechnical sample numbers (including field duplicate samples) and locations is presented in Table A.3-1, and their locations are shown in Figure A.3-1. Gaps in the numerical sample sequence represent sample numbers used for other projects and equipment, field, and trip blank (QC) samples; they are not included in this table, but are included in Section A.4.2.

Soil samples were analyzed for TPH gasoline range, TPH diesel range, and TC lead (Table A.3-1). Soil samples collected from boring SB-6 were also analyzed for Benzene, Toluene, Ethylbenzene, and Xylene (total) (BTEX). The TPH diesel range includes diesel, fuel oil \#2, and waste oil and are listed as separate results. Results for the analyses indicated the presence of TPH as diesel, gasoline, fuel oil \#2, and waste oil as well as lead and Xylene. The sample analytical parameters and laboratory analytical methods for the subsurface soil investigation are presented in Table A.3-2. The sample analytical parameters were selected through the application of the site process knowledge and preliminary sampling according to the U.S. Environmental Protection Agency (EPA) Data Quality Objectives (DQOs) process (EPA, 1994). The results of the DQO process are documented, in part, in the CAIP (DOE/NV, 1996a) with the remainder of the documentation retained in project files. Samples were analyzed by Quanterra Environmental Services in Earth City, Missouri. The parameters selected for analysis were based upon the anticipated COCs associated with the activities known to have been conducted at the site. 
Table A.3-1

Second Gas Station Sample List (Sheet 1 of 2)

\begin{tabular}{|c|c|c|c|c|c|}
\hline $\begin{array}{l}\text { Sample } \\
\text { Number }\end{array}$ & Boring & Sample Type & Depth (ft) & $\begin{array}{l}\text { UTM }{ }^{\mathrm{a}} \text { Northing } \\
\text { (NAD 83) }^{\mathrm{b}}\end{array}$ & $\begin{array}{l}\text { UTM Easting } \\
\text { (NAD 83) }\end{array}$ \\
\hline TTR00121 & SB-1 & Soil & 2 & 4182155.8 & 521432.853 \\
\hline TTR00122 & SB-1 & Soil & 32 & 4182155.8 & 521432.853 \\
\hline TTR00123 & SB-1 & Soil & 42 & 4182155.8 & 521432.853 \\
\hline TTR00124 & SB-4 & Soil & 22 & 4182168.743 & 521429.944 \\
\hline TTR00125 & SB-4 & Soil & 62 & 4182168.743 & 521429.944 \\
\hline TTR00126 & SB-4 & Soil & 71 & 4182168.743 & 521429.944 \\
\hline TTR00129 & SB-2 & Soil & 62 & 4182163.57 & 521429.98 \\
\hline TTR00138 & SB-2 & Soil & 72 & 4182163.57 & 521429.98 \\
\hline TTR00139 & SB-2 & Soil & 82 & 4182163.57 & 521429.98 \\
\hline TTR00140 & SO-2 & Soil & 32 & 4182169.51 & 521436.083 \\
\hline TTR00141 & $\mathrm{SO}-2$ & Soil & 62 & 4182169.51 & 521436.083 \\
\hline TTR00142 & so-2 & Soil & 72 & 4182169.51 & 521436.083 \\
\hline TTR00143 & SO-1 & Soil & 12 & 4182164.414 & 521434.484 \\
\hline TTR00144 & SO-1 & Soil & 72 & 4182164.414 & 521434.484 \\
\hline TTR00145 & SO-1 & Soil & 82 & 4182164.414 & 521434.484 \\
\hline TTR00147 & SB-1 & Soil & 72 & 4182155.8 & 521432.853 \\
\hline TTR00148 & SB-1 & Soil & 82 & 4182155.8 & 521432.853 \\
\hline TTR00149 & SB-3B & Soil & 32 & 4182165.883 & 521430.483 \\
\hline TTR00150 & SB-3B & Soil & 72 & 4182165.883 & 521430.483 \\
\hline TTR00151 & SB-3B & Soil & 82 & 4182165.883 & 521430.483 \\
\hline TTR00152 & SB-5 & Soil & 2 & 4182174.5 & 521433.065 \\
\hline TTR00153 & SB-5 & Soil & 22 & 4182174.5 & 521433.065 \\
\hline TTR00154 & SB-5 & Soil & 67 & 4182174.5 & 521433.065 \\
\hline TTR00155 & SB-5 & Soil & 72 & 4182174.5 & 521433.065 \\
\hline TTR00156 & SB-5 & Soil & 12 & 4182174.5 & 521433.065 \\
\hline TTR00157 & SB-5 & Field Duplicate & 12 & 4182174.5 & 521433.065 \\
\hline TTR00158 & SO-3B & Soil & 22 & 4182175.244 & 521427.481 \\
\hline TTR00159 & SO-3B & Soil & 72 & 4182175.244 & 521427.481 \\
\hline TTR00160 & SO-3B & Soil & 82 & 4182175.244 & 521427.481 \\
\hline TTR00161 & SO-5 & Soil & 22 & 4182178.683 & 521437.013 \\
\hline TTR00162 & SO-5 & Soil & 62 & 4182178.683 & 521437.013 \\
\hline TTR00163 & SO-5 & Soil & 72 & 4182178.683 & 521437.013 \\
\hline
\end{tabular}


Table A.3-1

Second Gas Station Sample List (Sheet 2 of 2)

\begin{tabular}{|c|c|c|c|c|c|}
\hline $\begin{array}{l}\text { Sample } \\
\text { Number }\end{array}$ & Boring & Sample Type & Depth $(f t)$ & $\begin{array}{l}\text { UTMa Northing } \\
\text { (NAD 83) }^{b}\end{array}$ & $\begin{array}{l}\text { UTM Easting } \\
\text { (NAD 83) }\end{array}$ \\
\hline TTR00164 & SO-3B & Soil Bioassay & 22 & 4182175.24 & 521427.481 \\
\hline TTR00165 & SO-6 & Soil & 22 & 4182180.61 & 521430.603 \\
\hline TTR00167. & SO-6 & Soil & 82 & 4182180.61 & 521430.603 \\
\hline TTR00168 & $\mathrm{SO}-4$ & Soil & 22 & 4182166.515 & 521425.255 \\
\hline TTR00169 & $\mathrm{SO}-4$ & Soil & 52 & 4182166.515 & 521425.255 \\
\hline TTR00170 & $\mathrm{SO}-4$ & Soil & 62 & 4182165.515 & 521425.255 \\
\hline TTR00173 & SO-7 & Soil & 22 & 4182181.832 & 521423.732 \\
\hline TTR00174 & SO-7 & Soil & 52 & 4182181.832 & 521423.732 \\
\hline TTRO0174DUP & SO-7 & $\begin{array}{c}\text { Soil-Laboratory } \\
\text { Duplicate }\end{array}$ & 52 & 4182181.832 & 521423.732 \\
\hline TTR00174MS & SO-7 & Soil-Matrix Spike & 52 & 4182181.832 & 521423.732 \\
\hline TTR00174MSD & SO-7 & $\begin{array}{c}\text { Soil-Matrix Spike } \\
\text { Duplicate }\end{array}$ & 52 & 4182181.832 & 521423.732 \\
\hline TTR00175 & SO-7 & Soil & 62 & 4182181.832 & 521423.732 \\
\hline TTR00176 & SO-7 & Field Duplicate & 61 & 4182181.832 & 521423.732 \\
\hline TTR00177 & SB-4 & Geotechnical & 52 & 4182168.743 & 521429.944 \\
\hline TTR00178 & SB-4 & Soil Bioassay & 32 & 4182168.743 & 521429.944 \\
\hline TTR00303 & SB-6 & Soil-Matrix Spike & 12 & 4181955.700 & 521506.610 \\
\hline TTR00303 & SB-6 & $\begin{array}{c}\text { Soil-Matrix Spike } \\
\text { Duplicate }\end{array}$ & 12 & 4181955.700 & 521506.610 \\
\hline TTR00304 & SB-6 & Soil & 12 & 4181955.700 & 521506.610 \\
\hline TTR00305 & SB-6 & Soil & 20 & 4181955.700 & 521506.610 \\
\hline TTR00306 & SB-6 & Field Duplicate & 20 & 4181955.700 & 521506.610 \\
\hline TTR00307 & SB-6 & Soil & 30 & 4181955.700 & 521506.610 \\
\hline
\end{tabular}

"UTM = Universal Transverse Mercator

${ }^{\mathrm{b}} \mathrm{NAD}=$ North American Datum 


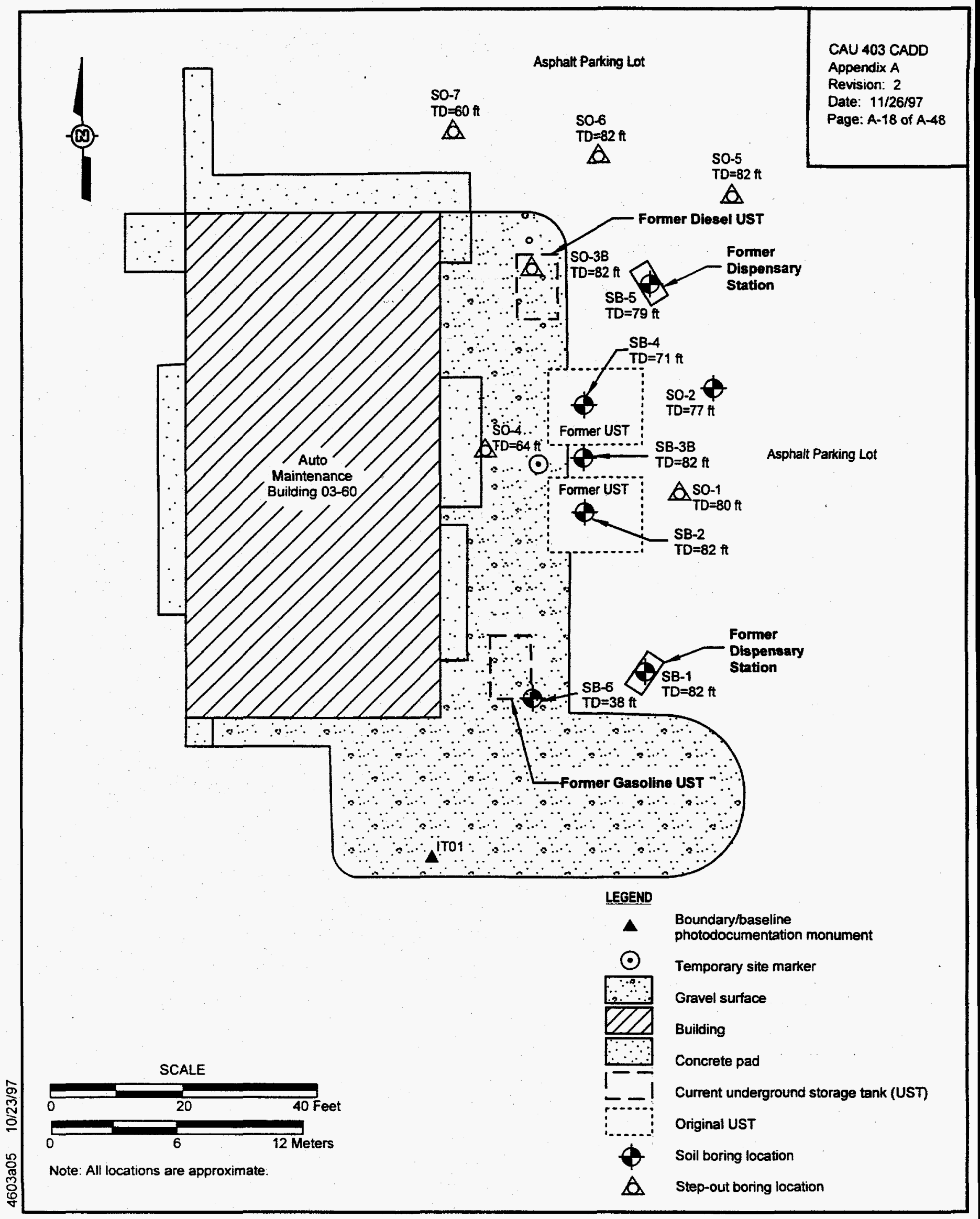

Figure A.3-1

Map of Soil Boring Locations, Second Gas Station, Tonopah Test Range 
Table A.3-2

Chemical Analytical Methods Used for Second Gas Station Investigation Samples

\begin{tabular}{|c|c|}
\hline Analytical Parameter & Analytical Method \\
\hline Total Petroleum Hydrocarbons (diesel and gasoline individually) & EPA 8015 (modified) \\
\hline${\text { TC }{ }^{\circ} \text { Lead }}^{\text {Benzene, Toluene, Ethylbenzene, } \text { Xylene }^{c} \text { (total) }}$ & EPA 6010 \\
\hline
\end{tabular}

U.S. Environmental Protection Agency SW-846 (EPA, 1992)

- Toxicity characteristic

'BTEX analyzed for samples collected from borehole SB- 6 only

\section{A.3.1 Data Quality Assessment}

The data quality was assessed to determine if the sampling objectives fully addressed the DQOs established in the CAIP (DOE/NV, 1996a). The DQOs of the CAIP indicated that the sampling objectives were to generate sufficient data to identify the presence of contamination, to determine the extent of contaminant migration, and to determine the appropriate closure recommendation.

The DQOs defined the boundaries of the study area as $15 \mathrm{ft}$ to $100 \mathrm{ft}$ bgs beneath where the USTs were believed to have been removed and below the locations of the fuel dispensary stations. The DQOs recognized that the Nevada Division of Environmental Protection requires that a determination be made about whether a regulated substance (TPH) was present in the soil and if it was above the action level of 100 milligrams per kilogram TPH (NAC, 1996). These sampling objectives were achieved through field screening and by laboratory analysis.

All samples were collected as required by the CAIP (DOE/NV, 1996a). Decision rules established by the DQO process and described in the CAIP were used for the decision criteria. In four boreholes, TPH levels exceeded the 100-ppm action level specified in the CAIP. A combination of field screening, process knowledge, and the decision criteria were used to supplement and guide the sampling process. 


\section{A.3.2 Sample Results}

Samples were analyzed for TPH as diesel and gasoline, TC lead, and BTEX. Significant levels of degraded diesel and gasoline were found in four boreholes (Table A.3-3 and Attachment 1). The most prevalent contaminant was diesel $(12,000 \mathrm{ppm})$ and waste oil $(1,500 \mathrm{ppm})$. Lesser amounts, but higher than the action limit of $100 \mathrm{ppm}$ of fuel oil $\# 2(210 \mathrm{ppm})$ and gasoline (150 ppm) were also noted. The highest concentrations (of diesel and gasoline) were found in boreholes SO-3B and SB-5 at $4 \mathrm{~m}$ to $7 \mathrm{~m}$ ( $12 \mathrm{ft}$ to $22 \mathrm{ft}$ ) below the ground surface (Table A.3-3). Lesser amounts, but greater

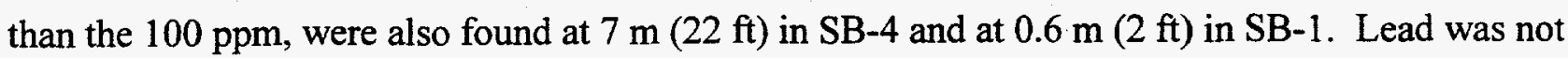
found at significant levels (i.e., above the EPA Region IX Preliminary Remediation Goals [PRGs] [EPA, 1996]) in any of the soil samples. Levels of gasoline ( $0.5 \mathrm{ppm})$ and Xylene (1.2 and $1.4 \mathrm{ppb})$ were insignificant at borehole SB-6.

Samples collected and screened from soil borings SB-5 and SO-3B demonstrated contamination from the surface to $9 \mathrm{~m}\left(30 \mathrm{ft}\right.$ ) bgs. Petroflag ${ }^{\mathrm{TM}}$ screening indicated that the TPH contamination

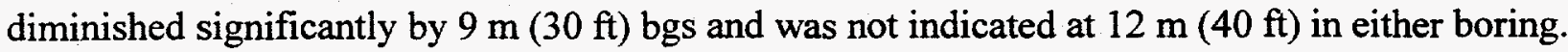

At SB-4, located over the originally approximated location of the north UST site, a soil sample indicated TPH contamination (diesel, $210 \mathrm{ppm}$ ) at a depth of $7 \mathrm{~m}(22 \mathrm{ft})$ bgs. Petroflag ${ }^{\mathrm{TM}}$ screening indicated hydrocarbons in lower concentrations at $9 \mathrm{~m}(30 \mathrm{ft})$ and no hydrocarbons at $12 \mathrm{~m}(40 \mathrm{ft})$. Hydrocarbons were not indicated at $3 \mathrm{~m}(10 \mathrm{ft})$.

Fuel oil \#2 (1,500 ppm) was indicated at $0.6 \mathrm{~m}(2 \mathrm{ft})$ in SB-1. Process knowledge suggested that SB-1 is located at the previous location of a gasoline dispensary station. The presence of fuel oil \#2 suggests surface contamination from sources other than that of the gasoline dispensary station. No other hydrocarbons were identified at other depths in SB-1.

Figure A.3-2 shows interpretations of the TPH diesel distribution at $6 \mathrm{~m}$ and $9 \mathrm{~m}$ ( $20 \mathrm{ft}$ and $30 \mathrm{ft}$ ) bgs for borings SB-5 and SO-3B. These boreholes had the highest TPH values noted. TPH diesel is plotted because it has the highest values wherever TPH was detected. Two interpretations presented for the TPH distribution indicated in SB-5 and SO-3B are that: (1) two independent, hydrocarbon plumes exist, or (2) the plumes coalesce at depth. 


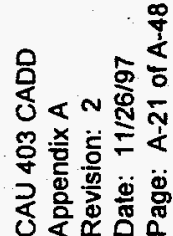
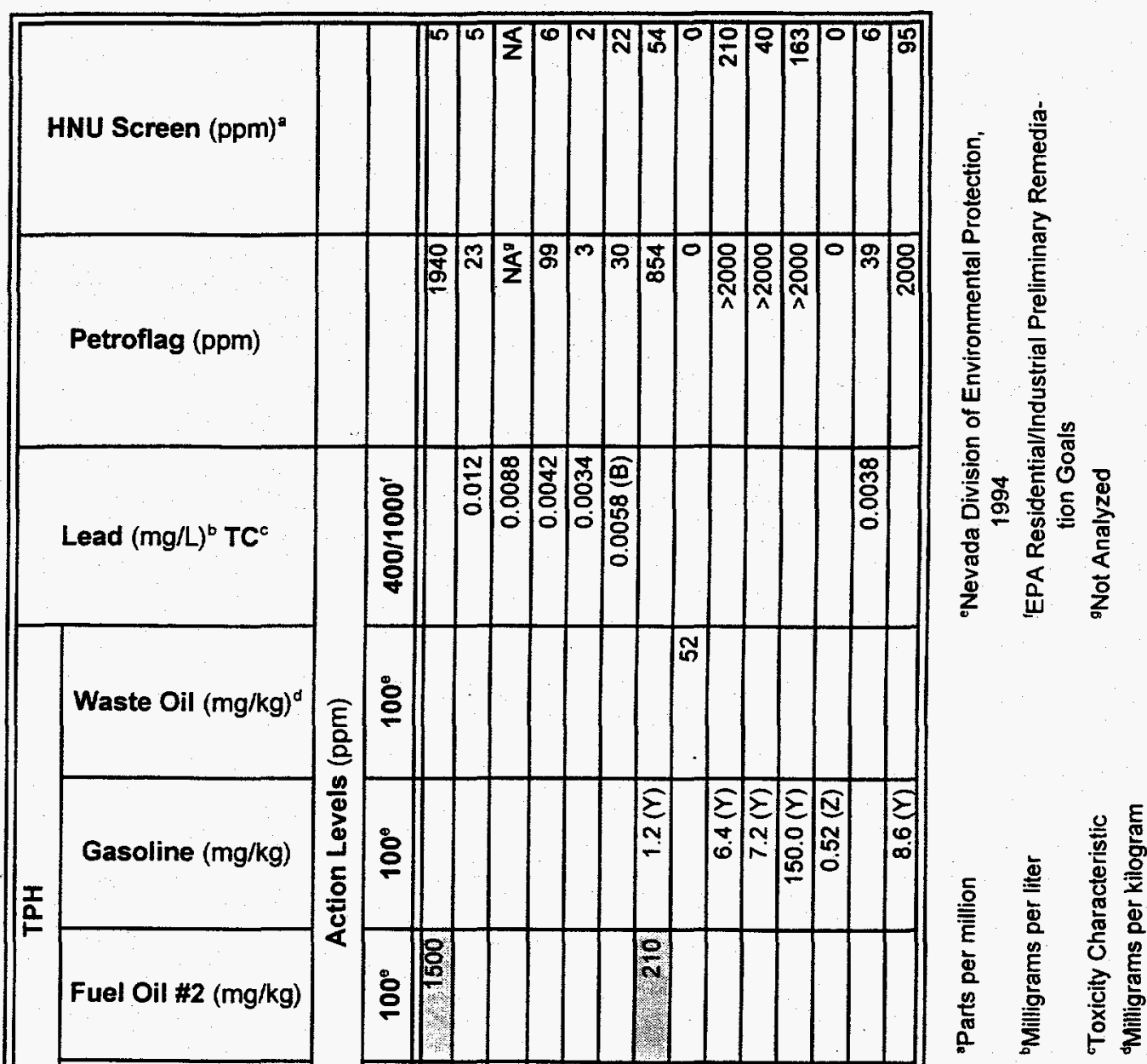

웅

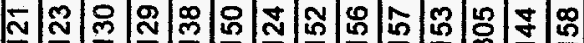

Sample Number

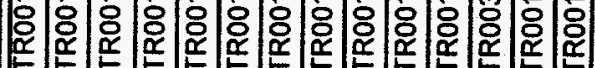

EIE E EIE E E E E E E E E E E E E

Sample Depth

(ft below ground surface)

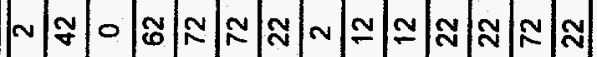

동

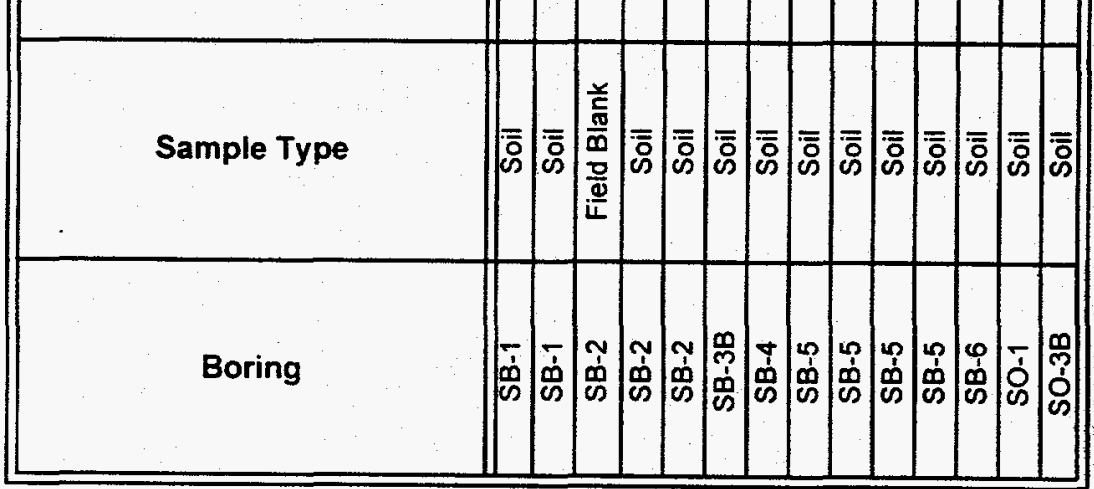

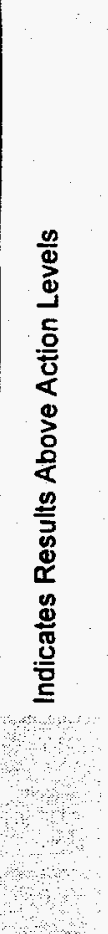

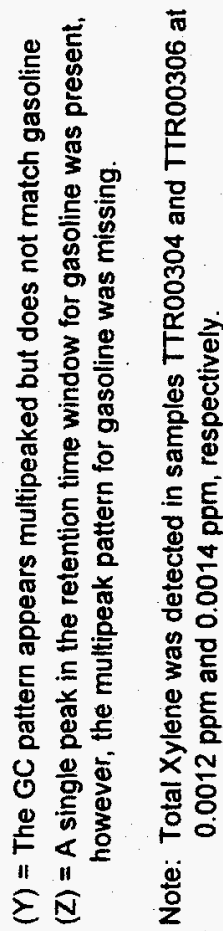




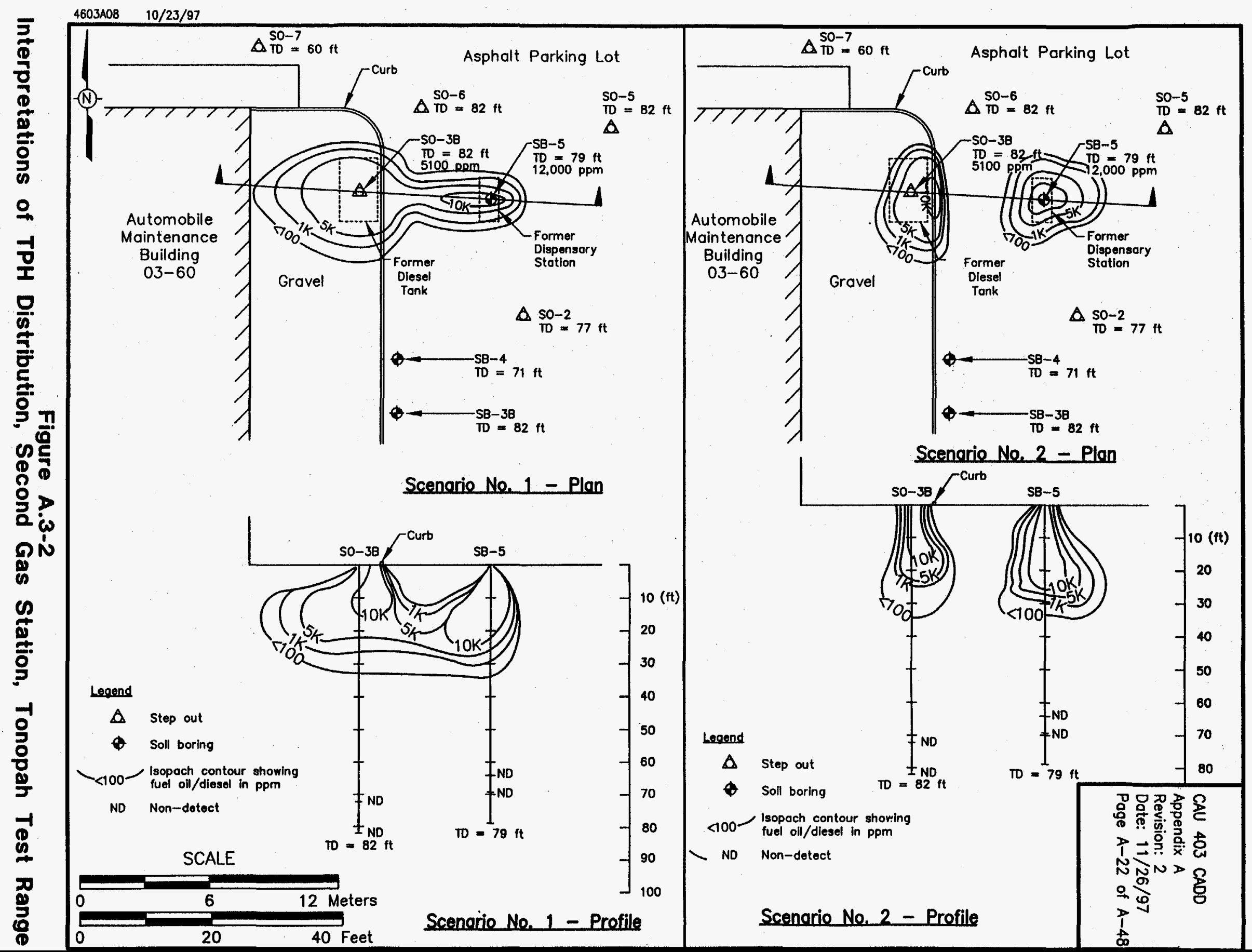


The vertical extent of the contamination in SB-5 and SO-3B, the boreholes with the highest TPH

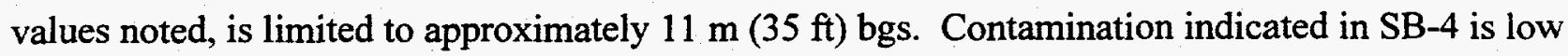
and is likely limited to $9-\mathrm{m}$ to $11-\mathrm{m}(30-\mathrm{ft}$ to $35-\mathrm{ft})$ depth as well as being limited laterally.

The results of the sampling at Second Gas Station are consistent with the conceptual model proposed in the CAIP (DOE/NV, 1996a). Contamination was predominantly diesel and heavy hydrocarbons likely associated with degradation of the diesel fuel. The potential for vertical migration is extremely low since the point sources are removed and annual precipitation is low. The lateral extent of the hydrocarbons is limited and will allow designation of boundaries to provide closure.

\section{A.3.3 Geotechnical and Bioassessment Samples}

Two bioassessment samples (TTR00164 and TTR00178) and one geotechnical sample (TTR00177) were collected from SO-3B (6 m [21.0 ft]) and SB-4 $(9 \mathrm{~m}[31.0 \mathrm{ft}])$, respectively. Both samples were collected and shipped in the brass sleeves in which they were collected. The sleeved samples were collected using a California Modified split-spoon sampler.

\section{A.3.3.1 Bioassessment Results}

The purpose of soil bioassessment was to determine if suitable conditions existed for bioremediation. Bioassessment is a series of tests designed to evaluate the physical, chemical, and microbiological characteristics of a site. The bioassessment consisted of nutrient determinations, $\mathrm{pH}$, microbial population density, and the ability of the microbial population to grow under enhanced conditions. The results of the bioassessment of samples TTR00164 and TTR00178 are summarized in the following text:

- Viable microbial populations existed at the site and appeared to be well-adapted to site conditions.

- Phosphate levels were elevated $(250 \mathrm{ppm})$, and ammonium levels were low $(<4 \mathrm{ppm})$.

- The heterotrophic, hydrocarbon-degrading microbial population reacted favorably to oxygen and nutrient stimulation. 
- The positive response of the microbes to nutrient enhancement during the stimulation test indicated that nutrient addition to the soil will be beneficial.

- The $\mathrm{pH}(8.4)$ was within the acceptable range for bioremediation.

- Moisture levels were acceptable.

\section{A.3.3.2 Geotechnical Analysis. Results}

Sample TTR00177 was submitted for geotechnical analysis which was performed at the IT Corporation Environmental Technology Development Center in Oak Ridge, Tennessee. The sample was analyzed for moisture content, particle-size distribution, undisturbed density, specific gravity, effective porosity, and permeability by flowing air.

Results of the geotechnical analyses found approximately 13 percent moisture content, a specific gravity of 2.65 grams per cubic centimeter, effective porosity of 36.8 percent, and air permeability of $1.85 \times 10^{-4}$ cubic meters per second. Sieve analysis found very coarse to fine sand with a 17 to 18 percent silt and clay content. Ten percent gravels were also noted in the analysis. 


\section{A.4.0 Quality Assurance}

The results of quality assurance (QA) and QC on characterization sampling activities for the Second Gas Station CAS are summarized in the following text. Also included is a discussion about measurement of the QA and QC objectives and documentation of nonconformances. Detailed information about the QA program for this sampling event is contained in the Industrial Sites QAPP (DOE/NV, 1996c).

\section{A.4.1 Quality Control Samples}

QC samples were collected and analyzed throughout the Second Gas Station sample collection process. A list of collected field QC samples is presented in Table A.4-1. A total of five field blanks, three equipment blanks, two matrix spike/matrix spike duplicate (MS/MSD), and three field duplicates were collected for analysis by an off-site laboratory. Field blanks were taken by placing distilled water into appropriate sample bottles under the same field conditions as the environmental samples and preserving them according to the requirements specified in the Industrial Sites QAPP (DOE/NV, 1996c). Equipment equipment blanks were obtained by collecting the final rinse solution (i.e., distilled water), pouring it over the decontaminated sampling equipment into the appropriate sample bottles, and preserving it, as applicable. The results of the QC samples are discussed in the following sections.

\section{A.4.1.1 Field Quality Control Samples}

Review of the field blank analytical data for the investigation sampling indicated that cross-contamination from field methods did not occur during sample collection. The field blanks were analyzed for the parameters listed in Table A.3-2, and none of the COCs was identified at concentrations above the laboratory method detection limits.

Equipment blanks were collected from the sampling equipment used during the investigation and were analyzed for the parameters listed in Table A.3-2. None of the COCs was identified at concentrations above detection limits in the equipment and source blanks. 


\section{Table A.4-1 \\ Second Gas Station Field Quality Control Samples Collected for Laboratory Analysis}

\begin{tabular}{|c|c|c|}
\hline Sample Number & Sample Type & Notes \\
\hline TTR00127 & Equipment blank & Sampling equipment \\
\hline TTR00128 & Field blank & Environmental effect sample \\
\hline TTR00130 & Field blank & Environmental effect sample \\
\hline TTR00146 & Field blank & Environmental effect sample \\
\hline TTR00171 & Field blank & Environmental effect sample \\
\hline TTR00172 & Equipment blank & Sampling equipment \\
\hline TTR00157 & Field Duplicate & Sampling Method Check \\
\hline TTR00174DUP & Laboratory Duplicate & Laboratory Method Check \\
\hline TTR00174MS & Matrix Spike & Laboratory Method Check \\
\hline TTR00174MSD & Matrix Spike Duplicate & Laboratory Method Check \\
\hline TTR00176 & Field Duplicate & Sampling Method Check \\
\hline TTR00301 & Equipment blank & Sampling equipment \\
\hline TTR00302 & Field blank & Environmental effect sample \\
\hline TTR00303 & Matrix Spike & Laboratory Method Check \\
\hline TTR00303 & Matrix Spike Duplicate & Laboratory Method Check \\
\hline TTR00306 & Field Duplicate & Sampling Method Check \\
\hline
\end{tabular}

During the actual sampling events, field duplicates (TTR00157, TTR00176, and TTR0306) were collected and analyzed for the same site investigation parameters listed in Table A.3-2. The field duplicate sampling result for TTR00157, indicating detected COCs, is listed in Table A.3-3. In sample TTR00157, diesel and traces of gasoline were detected in quantities similar to its duplicate sample TTR00156. Sample TTR00306 did not indicate a detected level of gasoline as its duplicate sample TTR00305 had; however, sample TTR00305 only indicated gasoline estimated at $20 \mathrm{ppb}$ above the detection limit.

Review of the analytical data for the field and equipment blanks indicated that the Second Gas Station soil samples were not contaminated during field activities or shipment. Cross-contamination due to incomplete decontamination did not occur. 


\section{A.4.1.2 Laboratory Quality Control Samples}

Analysis of method QC blanks and laboratory control samples was performed for each parameter analyzed by Quanterra Laboratories. Laboratory duplicate (sample split) analysis was performed on one sample from the investigation activities. Three samples were also designated for MS/MSD analysis. The laboratory duplicate results were considered to be in agreement with the original sample results. The complete $\mathrm{QC}$ sample results are maintained in the project files.

\section{A.4.2 Quality Assurance Objectives Measurements}

The QA objectives ensure that the analytical data collected are meaningful, defensible, and usable for the desired purposes. Measurement of specific QA objectives is discussed in the following sections.

\section{A.4.2.1 Precision}

Precision is a quantitative measure of the variability of a group of measurements from their average value. Additional information regarding the measurement of precision may be found in the Industrial Sites QAPP (DOE/NV, 1996c). Precision is assessed by collecting and analyzing duplicate field samples and comparing the results with the original sample. Precision is also assessed by creating, analyzing, and comparing laboratory duplicates from one or more field samples. It is reported as relative percent difference (RPD), which is calculated as the difference between the measured concentrations of duplicate samples, divided by the average of the two concentrations, and multiplied by 100 . For the subsurface soil sampling project, the accepted precision goals for the off-site laboratory analyses are specified in the Industrial Sites QAPP (DOE/NV, 1996c) and are listed in Table A.4-2, per the Industrial Sites QAPP (DOE/NV, 1996c) which also presents the results of measurement of precision for the Second Gas Station soil sampling data. The table lists the total number of RPD precision measurements by analysis type, the acceptable (i.e., target) RPD range per the Industrial Sites QAPP (DOE/NV, 1996c), and the number and percent of precision RPD measurements within the acceptance range.

The values shown in Table A.4-2 indicate the precision between field samples and the laboratory duplicates. All of the precision measurements were within the specified parameter-specific target 
Table A.4-2

Laboratory Precision Measurements for Second Gas Station Subsurface Soil Sampling Data

\begin{tabular}{|c|c|c|c|}
\hline \multirow{2}{*}{ Parameter } & \multicolumn{2}{|c|}{$\begin{array}{l}\text { Field and Laboratory Duplicate } \\
\text { Totals }\end{array}$} & \multirow{2}{*}{ Total } \\
\hline & TPH-G ${ }^{a}$ & TPH-D & \\
\hline $\begin{array}{c}\text { Total Number of RPD }{ }^{c} \text { Precision } \\
\text { Measurements }\end{array}$ & 1 & 2 & 3 \\
\hline Actual Range of Precision RPD Results & 35.3 & 1.26 to 7.9 & $N^{d}$ \\
\hline Target Range for Precision RPD ${ }^{c}$ & 0 to 40 & 0 to 40 & NA \\
\hline \multicolumn{4}{|l|}{$\begin{array}{l}\text { Number of Precision RPD Measurements } \\
\text { within }\end{array}$} \\
\hline Target Range & 1 & 2 & 3 \\
\hline \multicolumn{4}{|l|}{$\begin{array}{l}\text { Percent of Precision RPD Measurements } \\
\text { within }\end{array}$} \\
\hline Target Range & 100 & 100 & 100 \\
\hline
\end{tabular}

Total petroleum hydrocarbon - gasoline range

"Total petroleum hydrocarbon - diesel range

'Relative percent difference

'Not applicable

ranges. All on-site RPD measurements were within the established laboratory precision limits (see Table A.4-2).

\section{A.4.2.2 Accuracy}

Analytical accuracy is defined as the nearness of a measurement to the true or accepted reference value. It is the composite of the random and systematic components of the measurement system and measures bias in a measurement system. The random component of accuracy is measured and documented through the analyses of spiked samples. Sampling accuracy is assessed by evaluating the results of spiked samples and laboratory control samples. Accuracy measurements are calculated as percent recovery by dividing the measured sample concentration by the true concentration and multiplying the quotient by 100 . 
The target accuracy ranges established for the subsurface soil samples analyzed by the laboratory and the actual accuracies achieved are shown in Table A.4-3 for both matrix spike and laboratory control samples. Based on the results shown in this table, 100 percent of all QC sample recoveries were within the acceptable limits, which indicates excellent analytical accuracy. Additional information about measurement of accuracy for these samples is found in the Industrial Sites QAPP (DOE/NV, 1996c). Parameter-specific accuracy (percent recovery) measurements may be found in the laboratory analytical report data package maintained in the IT project files.

Field accuracy is assessed by confirming that the documents of record track the sample from its origin, through transfer of custody, to its disposal. The goal of field accuracy is for all samples to be collected from the correct locations at the correct time, placed in a correctly labeled container with the correct preservative, and to be sealed with custody tape to prevent tampering for both matrix spike and laboratory control samples.

Based on the results shown in this table, 100 percent of all QC sample recoveries were within the acceptable limits, which indicates excellent analytical accuracy. Additional information about measurement of accuracy for these samples is found in the Industrial Sites QAPP (DOE/NV, 1996c). Parameter-specific accuracy (percent recovery) measurements may be found in the laboratory analytical report data package maintained in the IT project files.

Field accuracy is assessed by confirming that the documents of record track the sample from its origin, through transfer of custody, to its disposal. The goal of field accuracy is for all samples to be collected from the correct locations at the correct time, placed in a correctly labeled container with the correct preservative, and to be sealed with custody tape to prevent tampering.

Any deviations from these requirements must be documented and explained, and the related data must be qualified accordingly. During the Second Gas Station sampling project, all field accuracy goals were met. 
Table A.4-3

Laboratory Accuracy Measurements for Second Gas Station Subsurface Soil Sampling Data

\begin{tabular}{|c|c|c|c|c|}
\hline \multirow{2}{*}{ Parameter } & \multicolumn{3}{|c|}{ Analysis } & \multirow{2}{*}{ Total } \\
\hline & TC ${ }^{a}$ Lead & $\mathrm{TPH}^{\mathrm{b}}$ Gasoline & TPH Diesel & \\
\hline Total Number of $\% R^{c}$ Measurements & 6 & 12 & 36 & 54 \\
\hline Matrix Spike Samples (range of actual \%R) & 107 & 77 to 110 & 97 to 105 & $N A^{d}$ \\
\hline Laboratory Control Samples (range of actual \%R) & 93 to 102 & 80 to 92 & 75 to 129 & NA \\
\hline$\% R$ Target Range (Soil) & 75 to 125 & 64 to 125 & 61 to 144 & NA \\
\hline $\begin{array}{c}\text { Number of \%R Measurements within the Target } \\
\text { Range }\end{array}$ & 6 & 11 & 36 & 53 \\
\hline $\begin{array}{c}\text { Percent of \%R Measurements within the Target } \\
\text { Range }\end{array}$ & 100 & 92 & 100 & 98 \\
\hline
\end{tabular}

Toxicity characteristic

'Total petroleum hydrocarbons

'Percent recovery

${ }^{\text {NNot applicable }}$

Reference: Industrial Sites QAPP (DOE/NV, 1996c) 


\section{A.4.2.3 Representativeness}

Representativeness expresses the degree to which sample data accurately and precisely represent a characteristic of a population, parameter variations at a sampling point, or an environmental condition (EPA, 1987). Sample representativeness is achieved through the implementation of a sampling program designed to ensure proper sampling locations, the number of samples, and the use of validated analytical methods. Representativeness may also be assessed through analysis of duplicate samples.

The Second Gas Station subsurface soil sampling project identified the COCs present in the soils and accurately and precisely quantified their concentrations. Samples were collected from predetermined intervals; collection and analysis were performed in accordance with approved procedures (IT, 1994); and both field and laboratory duplicates were analyzed. As a result, the Second Gas Station soil sampling data may be qualified as acceptably representative of site-specific environmental conditions. Additional information about the measurement of representativeness is found in the Industrial Sites QAPP (DOE/NV, 1996c).

\section{A.4.2.4 Completeness}

Completeness is defined as a percentage of measurements made that are judged to be valid. In general, the Second Gas Station subsurface soil sampling data exhibit a high degree of completeness. The subsurface soil sampling and analytical program was executed in accordance with the Field Sampling Instructions (IT, 1996a) and associated Records of Technical Change which are available upon request from IT project files. The specified sampling intervals were used as planned. All specified samples were collected and all sample containers reached the laboratory intact and properly preserved (if applicable). For all samples, sample temperature was maintained during shipment to the laboratory, and sample chain of custody was maintained during sample storage and shipment.

\section{A.4.2.5 Comparability}

Comparability is a qualitative parameter expressing the confidence with which one dataset can be compared to another (EPA, 1987). A standardized sampling approach and analytical methodology are used to achieve data comparability. To ensure comparability, all Second Gas Station field and 
laboratory activities were performed and documented in accordance with approved DOE contractor procedures (e.g., IT, 1994). Approved, standardized methods and procedures were also used to analyze and report the data (e.g., EPA, 1992). This approach ensured that the data from this project can be compared to other datasets.

\section{A.4.3 Field Deficiencies/Nonconformance}

On August 22, 1996, during the Second Gas Station subsurface sampling field operation, IT conducted a surveillance of the field operation to verify that sampling activities were performed in accordance with applicable requirements. The results of the surveillance indicated no findings, deficiencies, or nonconformances.

On September 20, 1996, a nonconformance occurred during shipping of samples to the off-site laboratory. Prior to shipping the samples, the sampling team failed to relinquish the samples. The integrity of the samples was not compromised in any other way due to this occurrence.

\section{A.4.4 Laboratory Nonconformances}

Laboratory nonconformances are generally due to inconsistencies in analytical instrumentation operation and fluctuations in internal standard and calibration results. A similar laboratory nonconformance was noted during analysis of the Second Gas Station samples. The nonconformance involved sample TTR00130, a field blank, which was analyzed two days beyond its holding time. The method 8015 modified for diesel is not significantly affected by the exceeded holding time because the samples are kept cold throughout the analysis. 


\section{A.5.0 References}

CFR, see Code of Federal Regulations.

Code of Federal Regulations. 1996. Title 40 CFR 258-271. Washington, DC: U.S. Government Printing Office.

Code of Federal Regulations. 1997. Title 40 CFR 172, "Hazardous Materials Table, Special Provisions, Hazardous Materials Communications, Emergency Response Information, and Training Requirements." Washington, DC: U.S. Government Printing Office.

Converse Environmental Consultants Southwest, Inc. 1994. Tank Removal Report, Area 3 Range Operation Center, Tonopah Test Range, Tonopah Test Range, NV. Sandia National Laboratories. Albuquerque, NM.

DOE, see U.S. Department of Energy.

EPA, see U.S. Environmental Protection Agency.

FFACO, see Federal Facility Agreement and Consent Order.

Federal Facility Agreement and Consent Order (FFACO). 1996. Agreed to by the Nevada Division of Environmental Protection, the U.S. Department of Energy, and the U.S. Department of Defense.

IT, see IT Corporation.

IT Corporation. 1994. Standard Quality Practices. Las Vegas, NV.

IT Corporation. 1996a. "Field Instruction for Subsurface Soil Characterization, the Second Gas Station Underground Storage Tanks and the Roller Coaster Sewage Lagoons Outfall Pipe Area at Tonopah Test Range, NV." Las Vegas, NV.

IT Corporation. 1996b. Site-Specific Health and Safety Plan, Second Gas Station, Tonopah Test Range, $N V$. Las Vegas, NV.

NAC, see Nevada Administrative Code.

Nevada Administrative Code. 1996. NAC 459, "Hazardous Materials." Carson City, NV.

NDEP, see Nevada Division of Environmental Protection. 
Nevada Division of Environmental Protection. 1994. Nevada Underground Storage Tank Procedures. Carson City, NV.

U.S. Department of Energy, Nevada Operations Office. 1996a. Corrective Action Investigation Plan: Second Gas Station Underground Storage Tanks, Tonopah Test Range, Rev. 1. Las Vegas, NV.

U.S. Department of Energy, Nevada Operations Office. 1996b. Draft Report, Corrective Action Unit Work Plan, Tonopah Test Range. Las Vegas, NV.

U.S. Department of Energy, Nevada Operations Office. 1996c. Industrial Sites Quality Assurance Project Plan, DOE/NV-425. Las Vegas, NV.

U.S. Environmental Protection Agency. 1992. Test Methods for Evaluating Solid Waste, Physical/Chemical Methods, SW-846, PB89-148076. Washington, DC.

U.S. Environmental Protection Agency. 1987. Data Quality Objectives for Remedial Response Activities, EPA/540/G-87-003. Washington, DC.

U.S. Environmental Protection Agency. 1994. Guidance for the Data Quality Objectives Process, EPA QA/G-4. Washington, DC.

U.S. Environmental Protection Agency. 1996. "Region 9 Preliminary Remediation Goals (PRGs) 1996." In a memorandum from Stanford J. Smucker, Ph.D., Regional Toxicologist, Technical Support Team to the PRG Table Mailing List, 1 August. 
CAU 403 CADD

Appendix A

Revision: 2

Date: 11/26/97

Page: A-35 of A-48

Attachment 1

\section{Boring Logs}




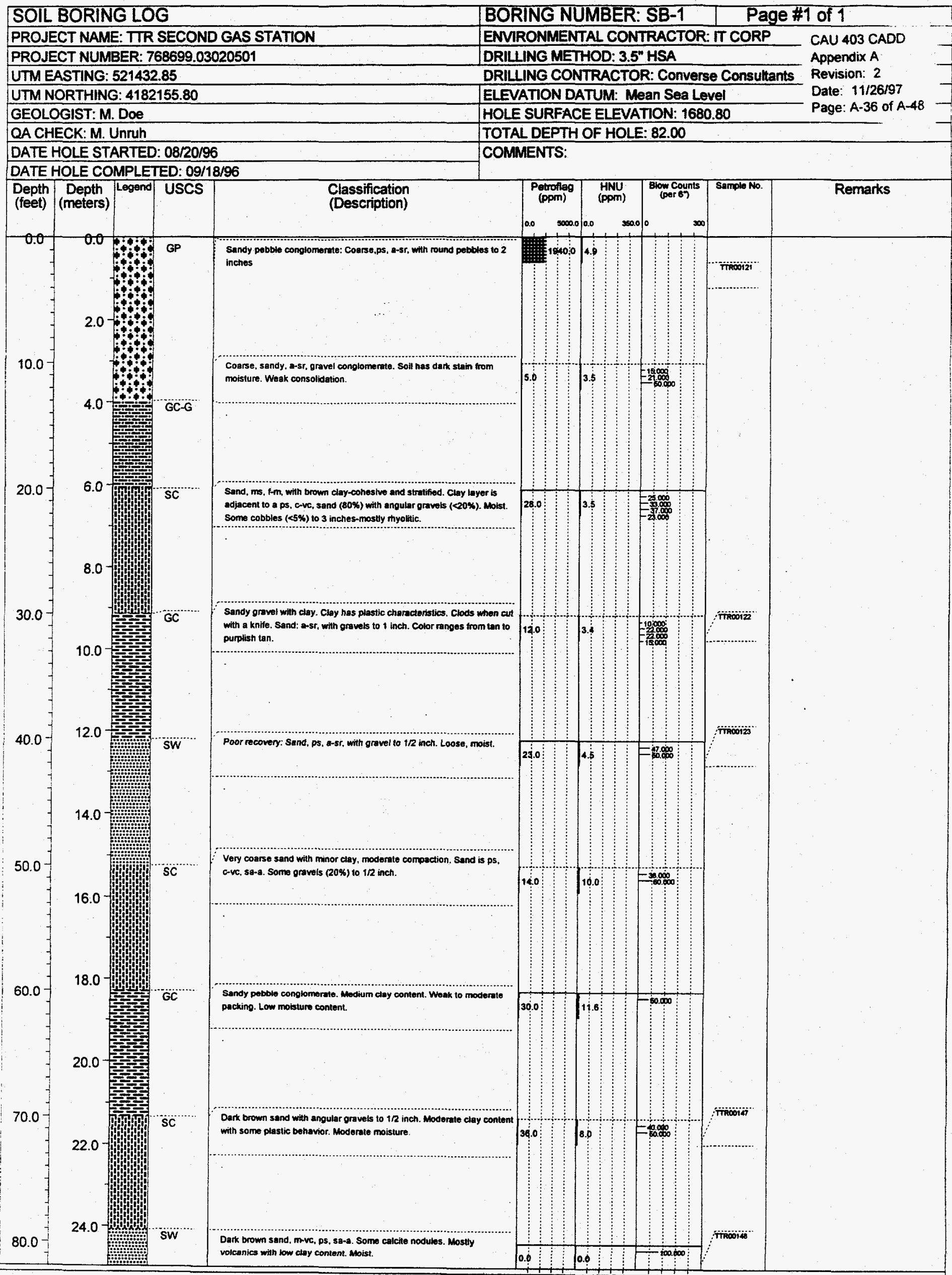




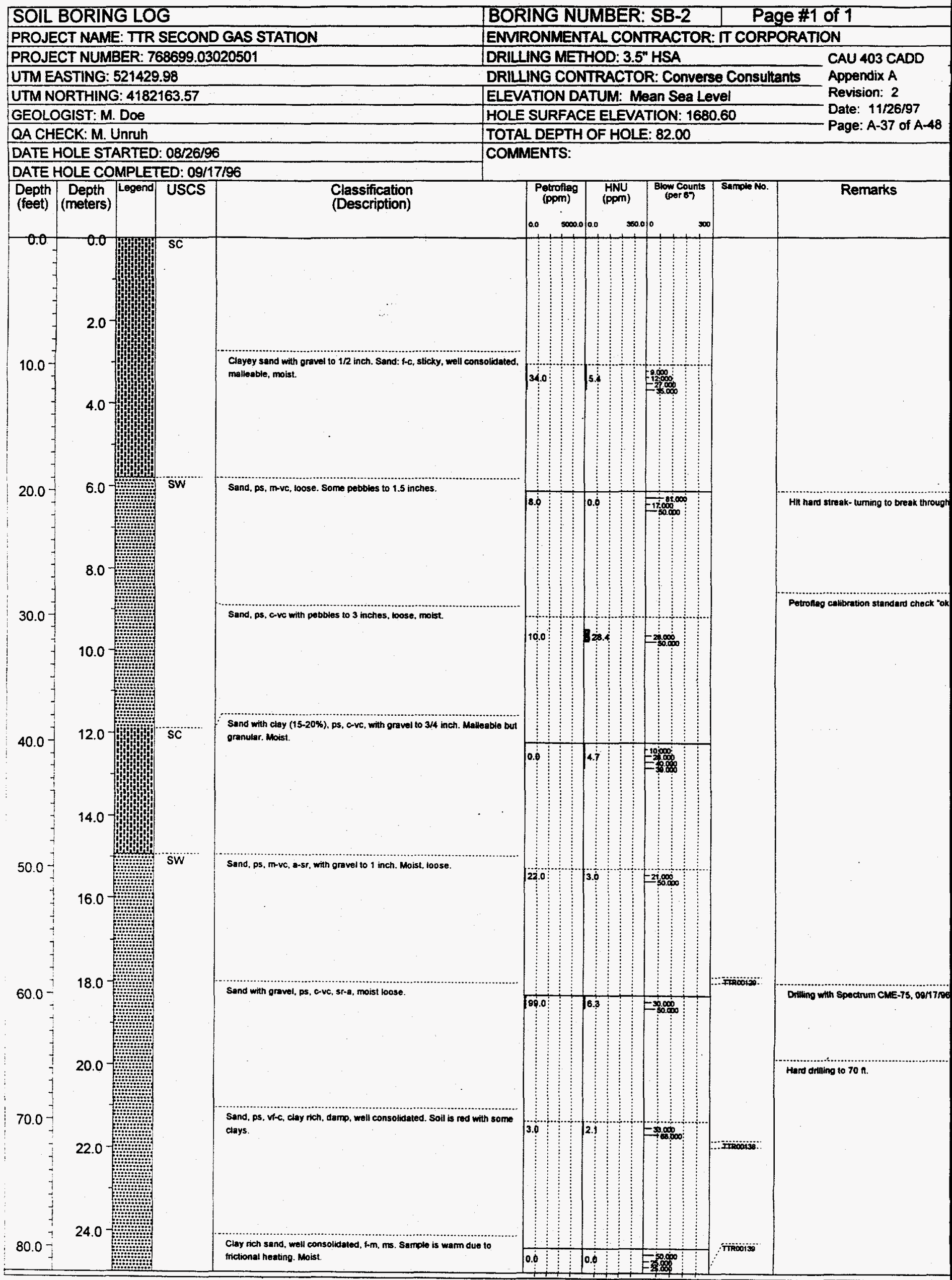




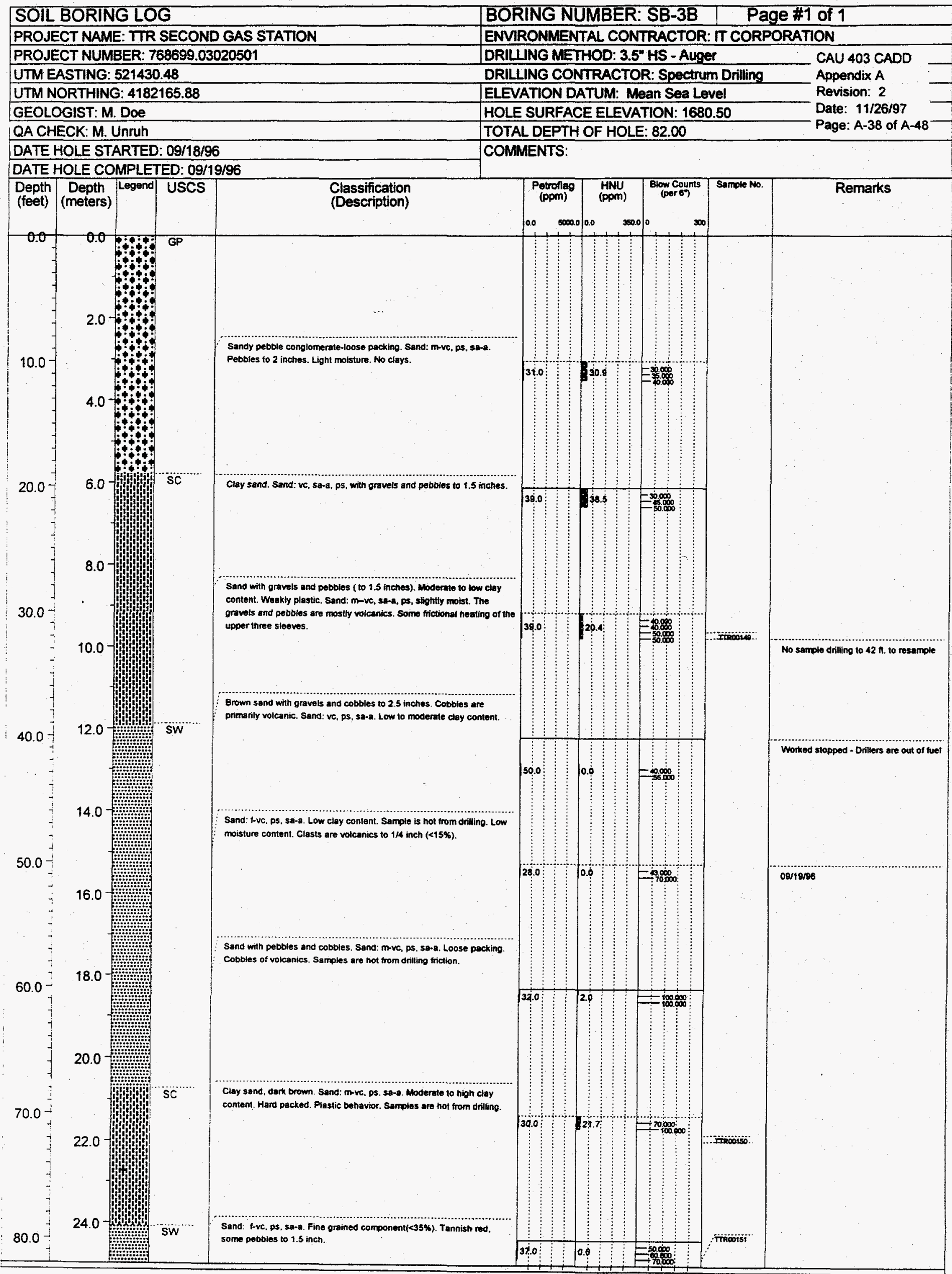




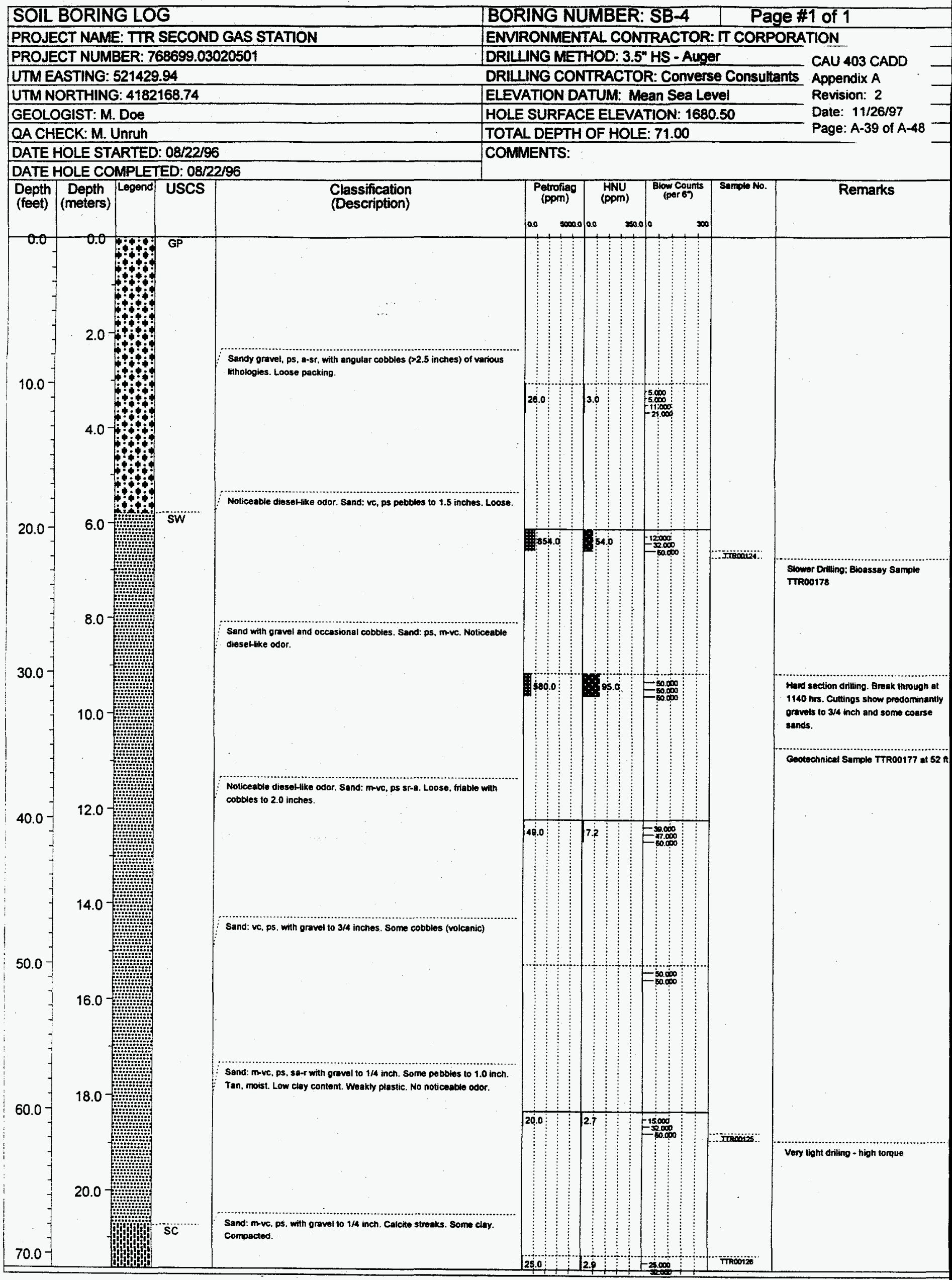




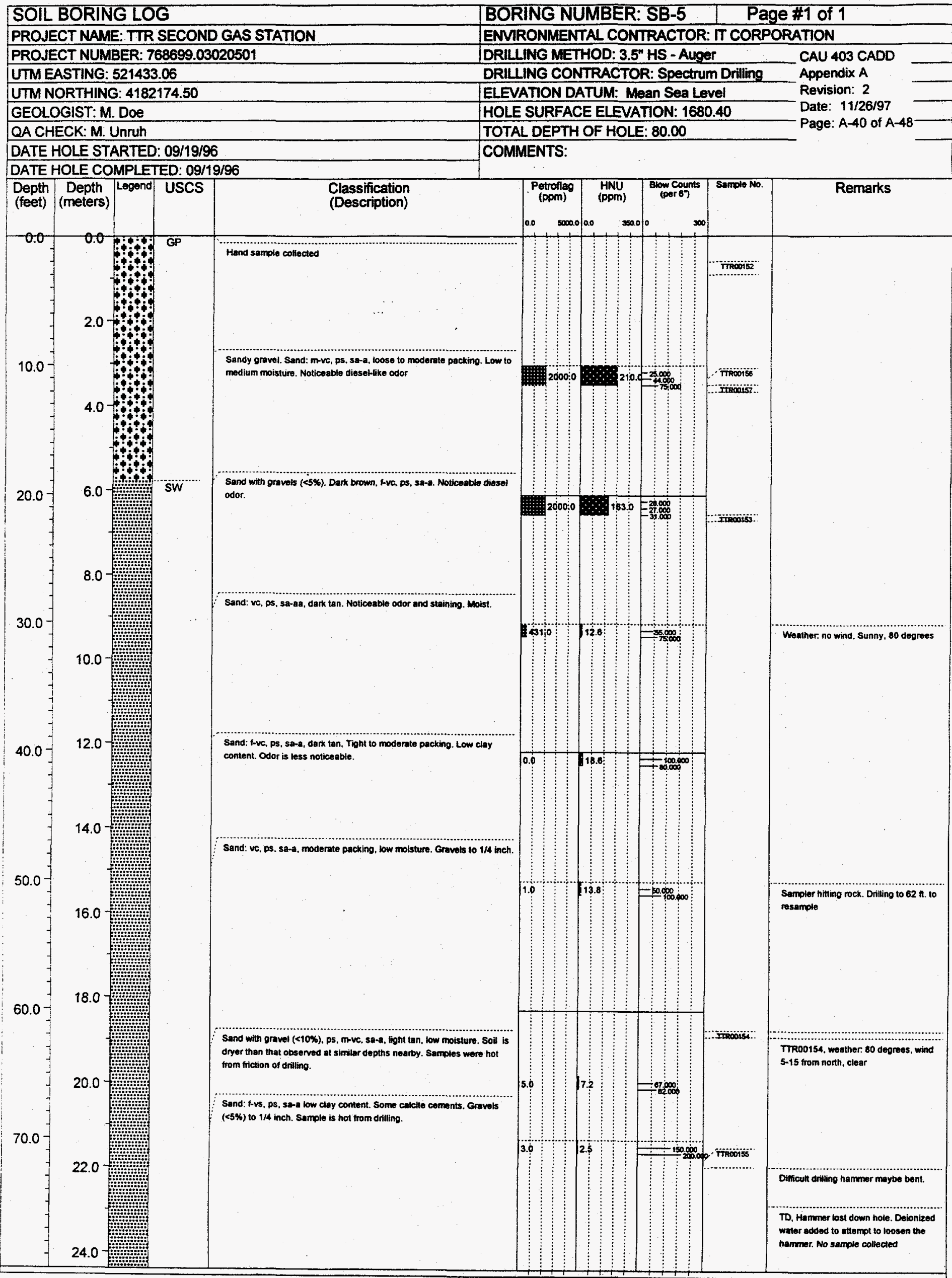




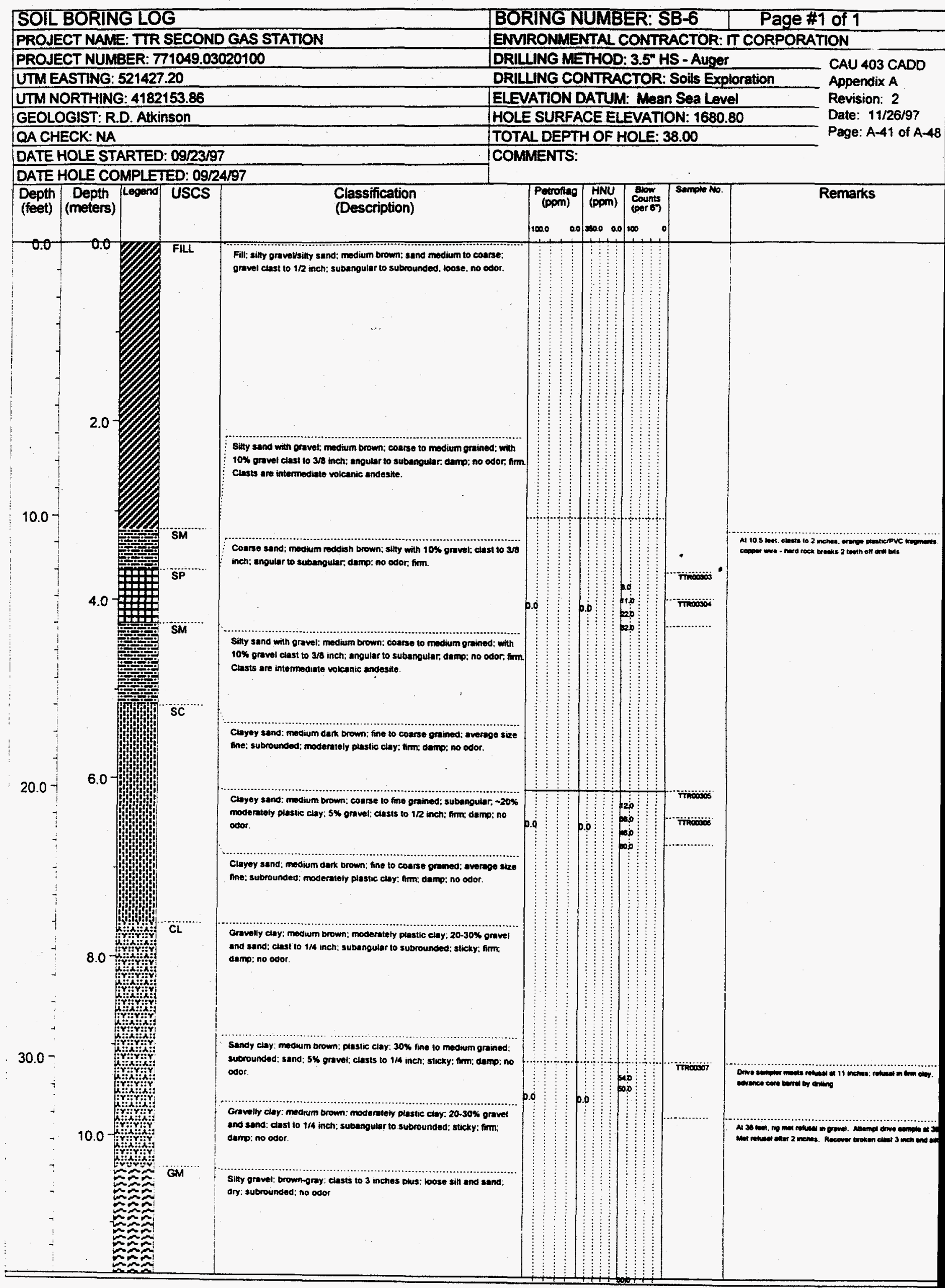




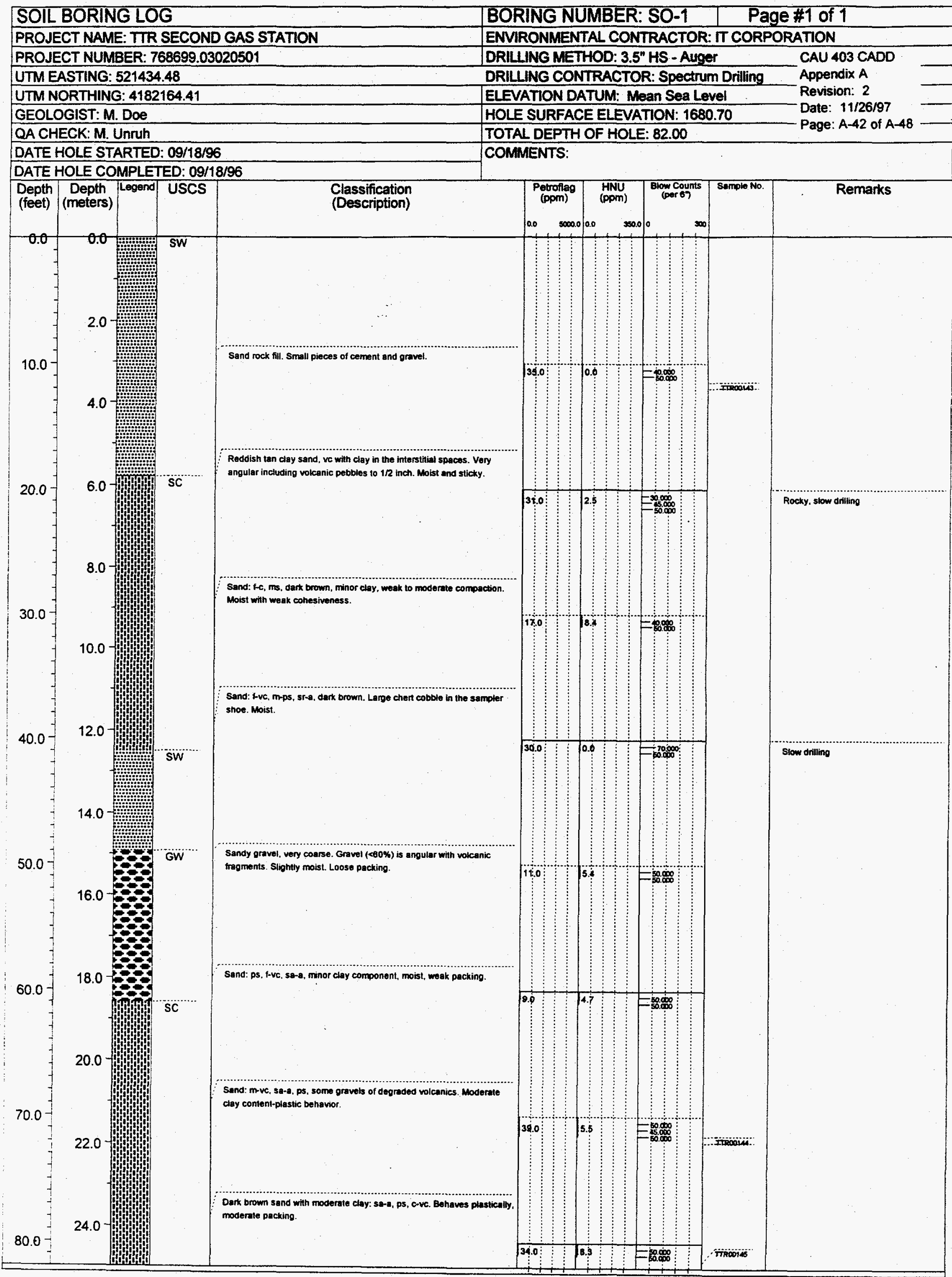




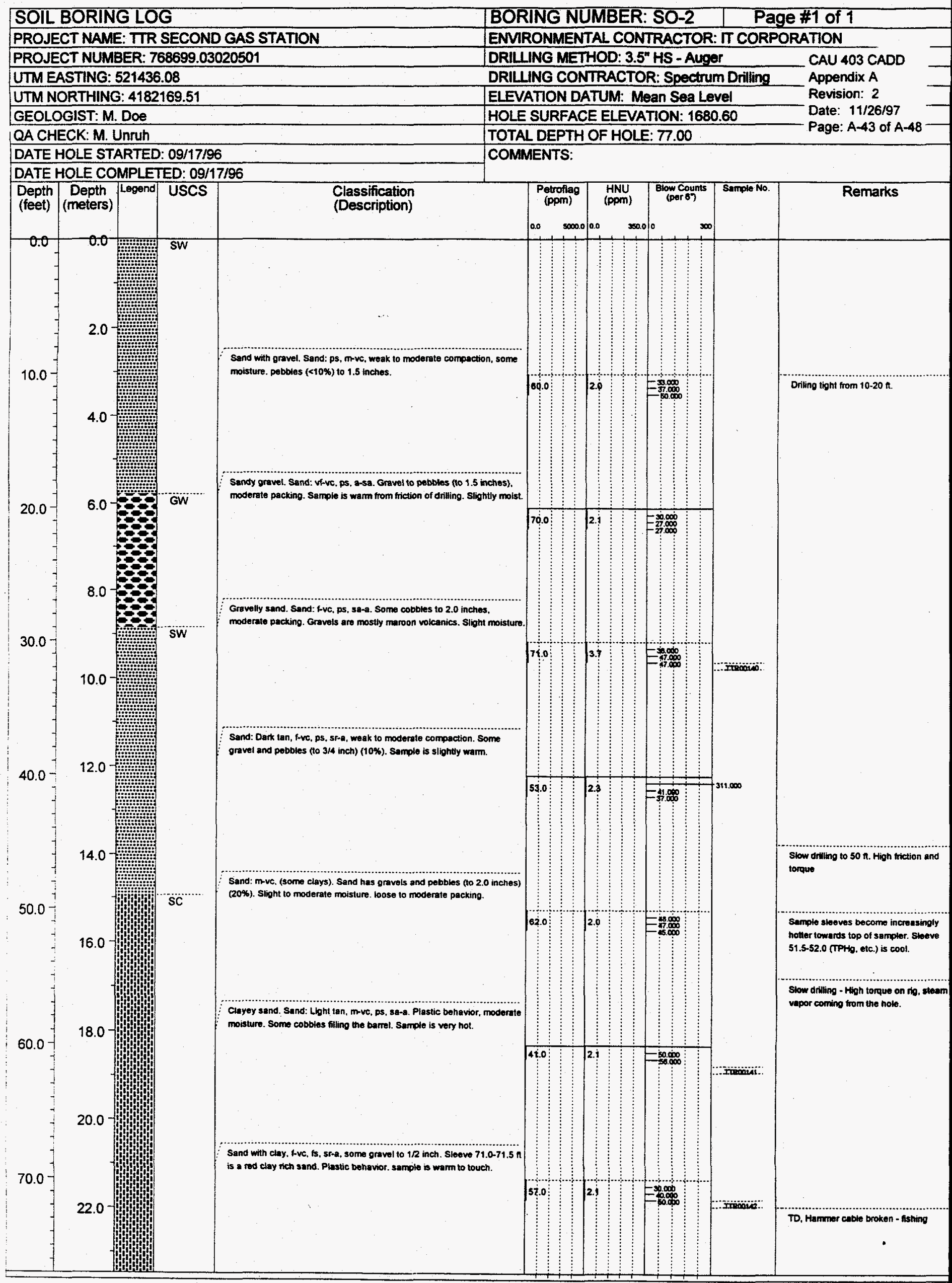


SOIL BORING LOG

PROJECT NAME: TTR SECOND GAS STATION

PROJECT NUMBER: 768699.03020501

UTM EASTING: 521427.48

UTM NORTHING: 4182175.24

GEOLOGIST: M. Doe

QA CHECK: $M$. Unruh

DATE HOLE STARTED: 09/24/96

DATE HOLE COMPLETED: 09/24/96

Depth Depth Legend USCS

(feet) (meters)

0.0

\begin{tabular}{|c|c|c|c|}
\hline-0.0 & 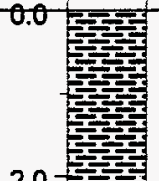 & $\overline{G C}$ & \\
\hline & 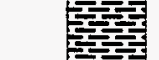 & & $\begin{array}{l}\text { Sandy gravel - noticesble diesel odor. Sand: } m \text {-vc, ps, sa-a, moderate } \\
\text { ctay, sticky behavior, moist. }\end{array}$ \\
\hline
\end{tabular}

10.0

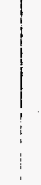

20.0

6.0

sw

$40.0^{-}$

0 -

$$
10.0
$$

8.0

…

盘

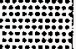

$50.0-$

$$
14.0
$$

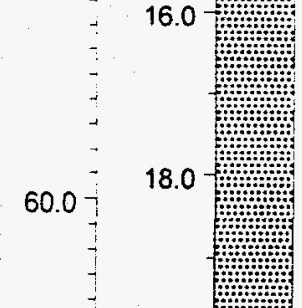

16.0

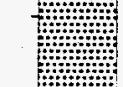

20.0

70.0

ctay, sticky behavior, moist

Gravelly sand - noticeable dieset odor. Sand: m-vc, ps, sqa-a. Gravets to $3 / 4$ inch. Damo toose packing.

Sandy gravet noticeable odor. Sand: m-vc, ps, a-sa loose packing Some pebbles to 2 inches. Low clay content.

Sand: f-vc. ps. sr-a. with gravels to $1 / 4$ inch. Sight odor. Madium to tight packing. Low to medium moisture.

Sand with catcite streaks, m-vc, ps, sa-a, low clay content, tow moisture tan, some gravels $(<15 \%)$ to $1 / 2$ inch.

Sand wath gravel. Sand: m-ve, ps sa-a, low moisture.

$$
\text { . }
$$

Gravelly sand. Notceable odor. Variable moisture: low to damp. May be slough. Nole: sticky slough in the top of the samplet.

Sand with calcite streaks. ps, m.vc. sa-a. Low moisture. Well comented. DRILLING METHOD: 3.5" HS - Auger CAU 403 CADD DRILING CONTRACTOR: Spectrum Drilling

Appendix A

ATION DATUM: Mean Sea Level

Revision: 2

HOLE SURFACE ELEVATION: 1680.20

Date: $11 / 26 / 97$

TOTAL DEPTH OF HOLE: 82.00

Page: A-44 of A-48 COMMENTS: 


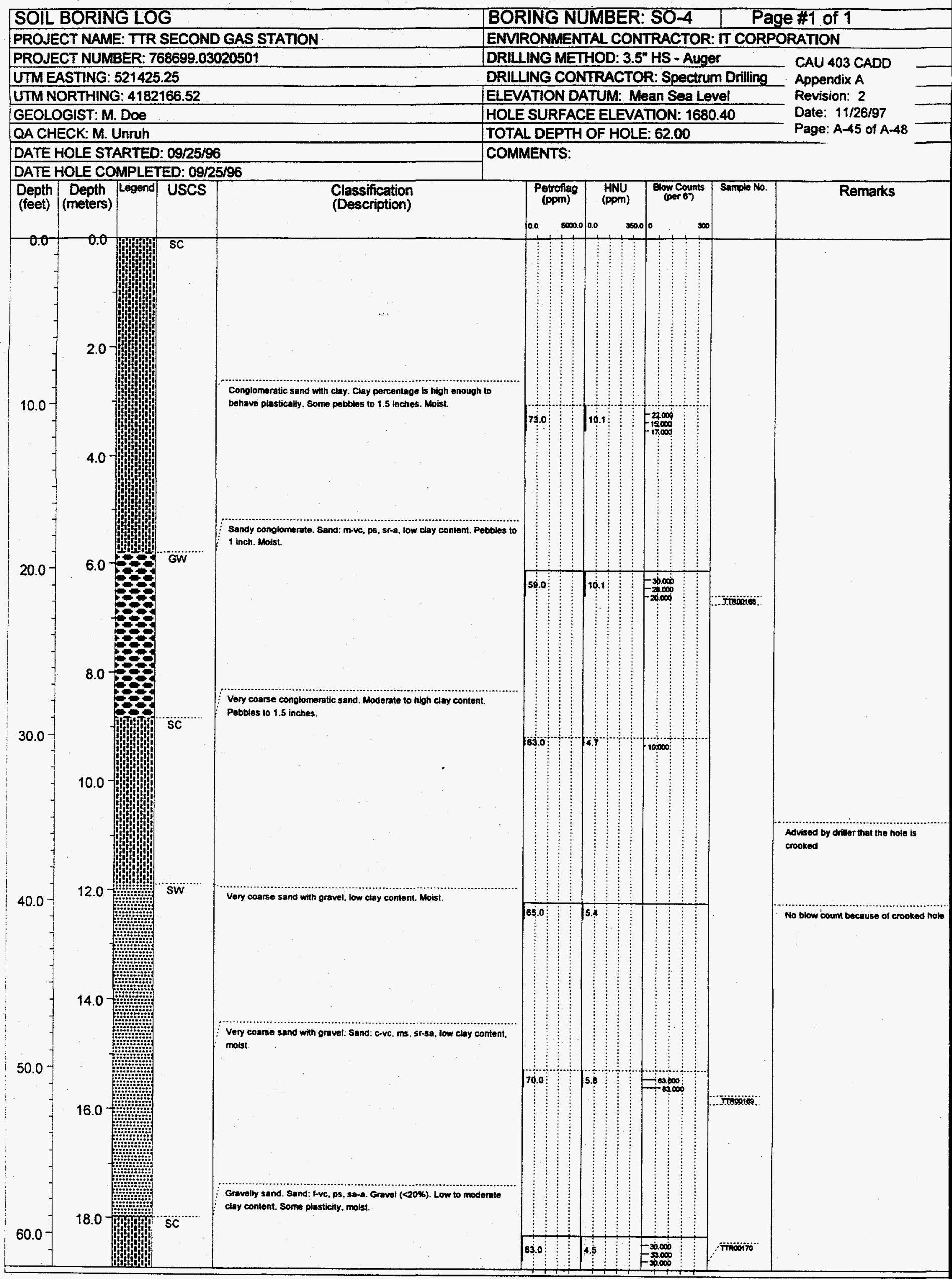




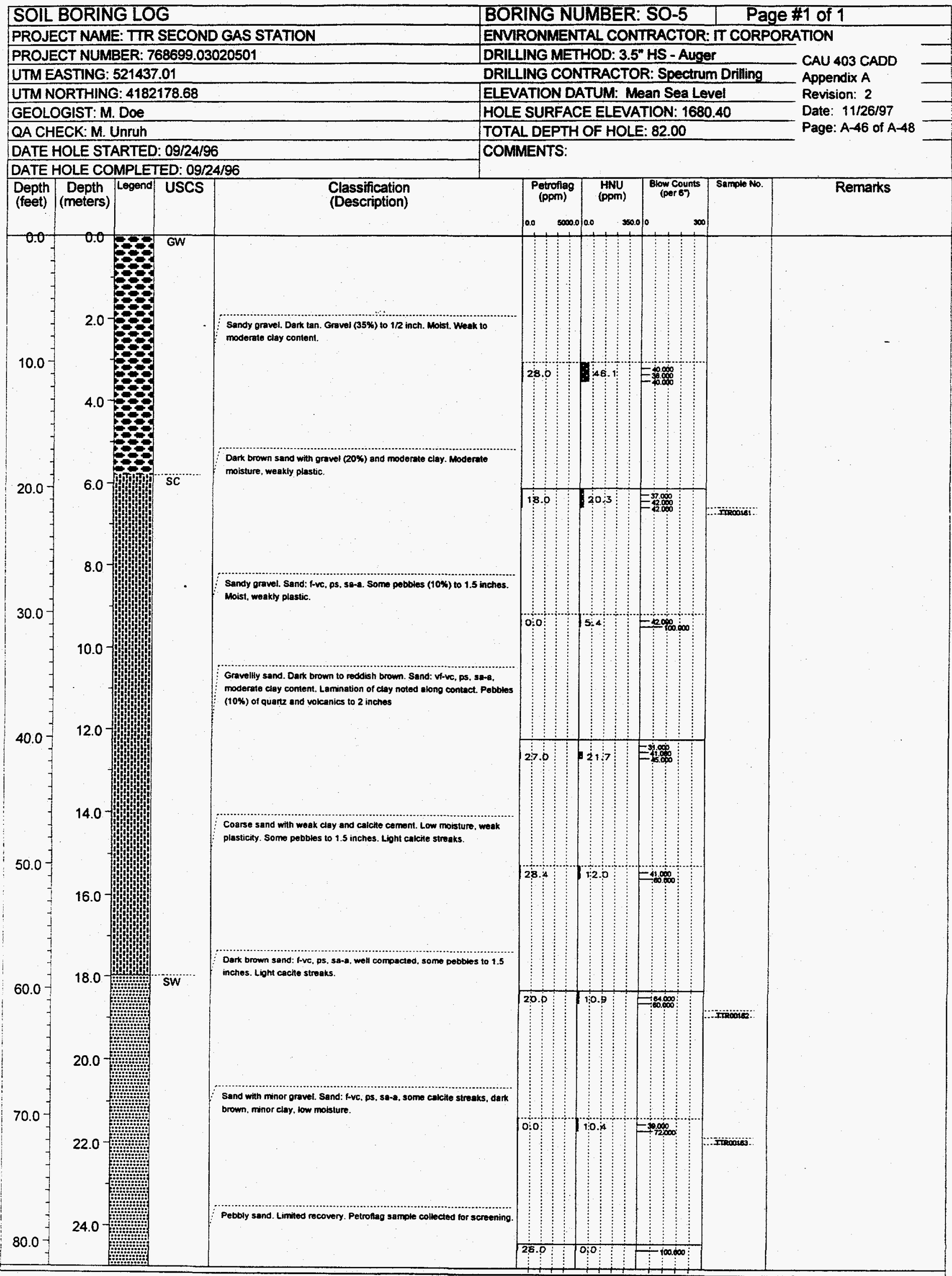




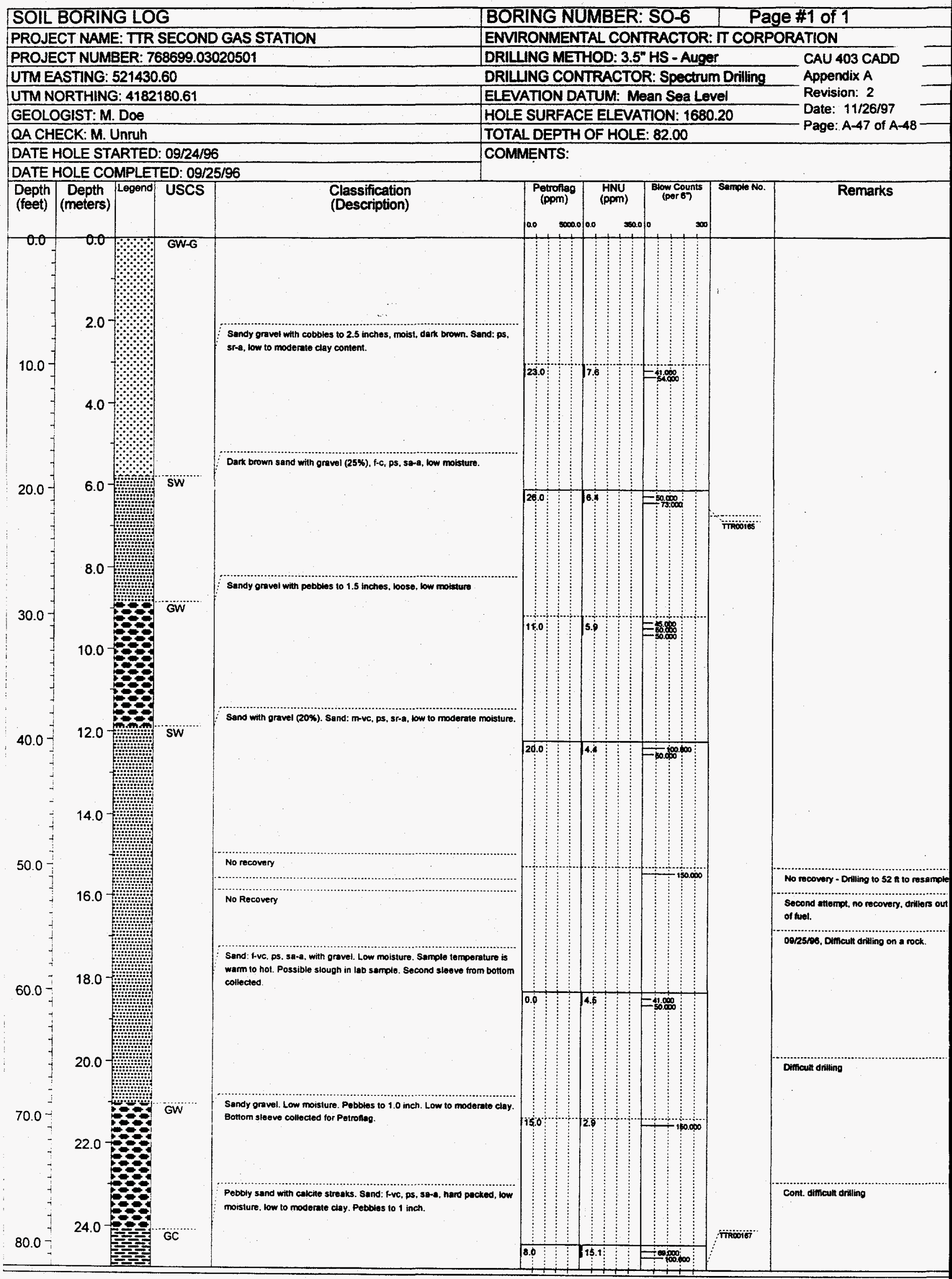




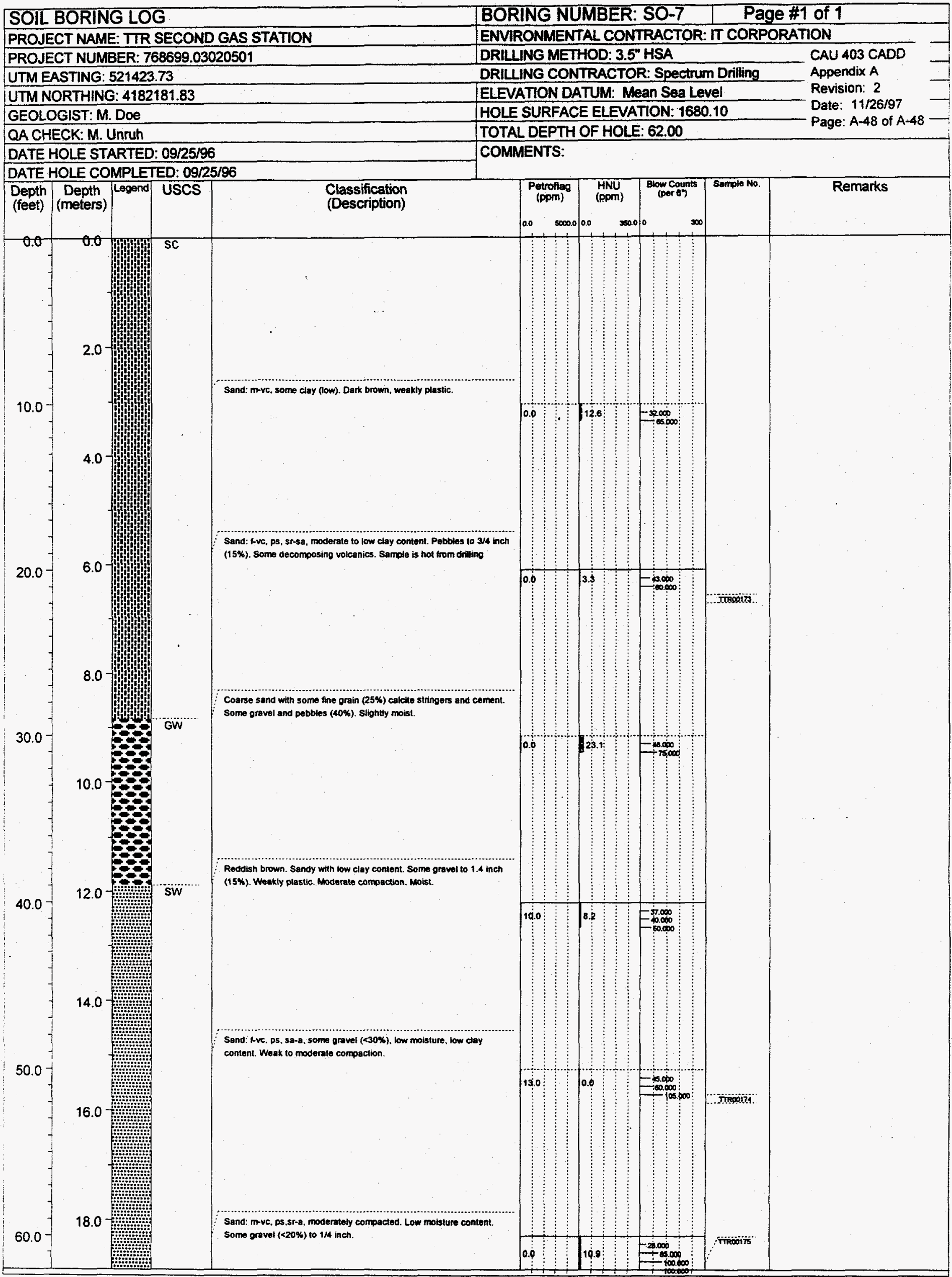


Appendix B

Cost Estimates 


\section{Basis of Estimate}

1. The average soil density is 96 pounds per cubic foot.

2. The soil volume includes $25 \%$ for expansion.

3. The contaminated volume to be excavated is 1,200 cubic meters $\left(\mathrm{m}^{3}\right)$ (1,570 cubic yards [ $\left.\left.\mathrm{yd}^{3}\right]\right)$, with expansion $\left(1,960 \mathrm{yd}^{3}\right)$.

4. The soil contamination is hydrocarbons, assumed disposal in Las Vegas.

5. Transportation will be by subcontract carrier, transportation TTR to LV $\$ 15$ per ton, disposal fee $\$ 15$ per ton, (resent quote).

6. Fifteen trucks required with $17 \mathrm{yd}^{3}$ per load capacity, the cycle time for disposal is two days.

7. The average truck speed is $45 \mathrm{MPH}$, the distance is 220 miles one way.

8. The cycle time for each truck for the local fill is three loads per day.

9. The crew and equipment (excluding the 15 dump trucks) are Bechtel Nevada, FY 1997 rates.

10. G\&A adder of $13 \%$ is included for the subcontracted work.

11. Costs for in situ bioremediation are based on similar IT work.

12. The sampling for bioremediation will be performed once per month for 17 months. 
Table B-1

IT Corporation Estimate Sheet

(Sheet 1 of 4)

\begin{tabular}{|c|c|c|c|c|c|c|c|c|}
\hline & $\begin{array}{c}\text { Project: Second Gas Station CADD } \\
\text { Location: TTR }\end{array}$ & & & & & $\begin{array}{c}\text { Date: } \\
\text { Revision: }\end{array}$ & $\begin{array}{c}6 / 11 / 97 \\
B\end{array}$ & \\
\hline Item & Description & Quan. & Unit & Matl. & Labor & Subcontr. & Total & G\&A \\
\hline 1.0 & FENCING \& SIGNS & & & & & & & \\
\hline 1.1 & 6' industrial chain-link fencing with barbed wire & 150 & L.F. & & & $\$ 22.50$ & $\$ 3,375$ & $\$ 439$ \\
\hline & Aluminized corner posts & 4 & EA & & & $\$ 128$ & $\$ 512$ & $\$ 67$ \\
\hline & $20^{\prime}$ swing gate & 1 & EA & & & $\$ 1,140$ & $\$ 1,140$ & $\$ 148$ \\
\hline 1.2 & Signs & 4 & EA & & & $\$ 500$ & $\$ 2,000$ & $\$ 260$ \\
\hline 1.3 & Subcontract G\&A & & & & & & $\$ 914$ & \\
\hline \multicolumn{7}{|c|}{ FENCING \& SIGNS SUBTOTAL } & $\$ 7,941$ & \\
\hline 2.0 & EXCAVATE (1960 CY) \& DISPOSAL & & & & & & & \\
\hline \multirow[t]{5}{*}{2.1} & MOBILIZATION & & & & & & & \\
\hline & $\begin{array}{l}\text { Dump Trucks@ } 15 \text { (8 Hr day plus per diem } \\
\text { \$625/day/truck) }\end{array}$ & 2 & DAY & & & $\$ 9,375$ & $\$ 18,750$ & $\$ 2,438$ \\
\hline & WaterTruck@1 & 2 & DAY & $\$ 133$ & & & $\$ 266$ & \\
\hline & Backhoe@1 & 2 & DAY & $\$ 136$ & & & $\$ 272$ & \\
\hline & Front End Loader @ 2 & 2 & DAY & $\$ 272$ & & & $\$ 544$ & \\
\hline \multicolumn{7}{|r|}{ SUBTOTAL } & $\$ 19,832$ & \\
\hline \multirow[t]{13}{*}{2.2} & EXCAVATION/LOAD/TRANSPORTIDISPOSAL & & & & & & & \\
\hline & $\begin{array}{l}\text { Dump Trucks \& Driver Transport } \\
\text { (\$15/ton) }\end{array}$ & 2,548 & TON & & & $\$ 15$ & $\$ 38,220$ & $\$ 4,969$ \\
\hline & Disposal \& Treatment & 2,548 & TON & & & $\$ 15$ & $\$ 38,220$ & $\$ 4,969$ \\
\hline & Analytical-VOL 8240 & 1 & EA & & & $\$ 195$ & $\$ 195$ & $\$ 25$ \\
\hline & WaterTruck@1 & 16 & DAY & $\$ 133$ & & & $\$ 2,128$ & \\
\hline & Front End Loader @ 2 & 16 & DAY & $\$ 272$ & & & $\$ 4,352$ & \\
\hline & Backhoe @ 1 & 20 & DAY & $\$ 136$ & & & $\$ 2,720$ & \\
\hline & Superintendent @1 & 20 & DAY & & $\$ 990$ & & $\$ 19,800$ & \\
\hline & Equipment Operator @ 1 & 20 & DAY & & $\$ 720$ & & $\$ 14,400$ & \\
\hline & Equipment Operator @ 2 & 16 & DAY & & $\begin{array}{r}\$ 1,44 \\
0\end{array}$ & & $\$ 23,040$ & \\
\hline & Driver@ 1 for Water Truck & 16 & DAY & & $\$ 720$ & & $\$ 11,520$ & \\
\hline & TTR Per Diem @ 3 x \$36/day & 16 & DAY & $\$ 108$ & & & $\$ 1,728$ & \\
\hline & TTR Per Diem @ 2 × \$36/day & 20 & DAY & $\$ 72$ & & & $\$ 1,440$ & \\
\hline \multicolumn{7}{|r|}{ SUBTOTAL } & $\$ 157,763$ & \\
\hline 2.3 & DEMOBILIZATION & & & & & & & \\
\hline
\end{tabular}


Table B-1

IT Corporation Estimate Sheet

(Sheet 2 of 4 )

\begin{tabular}{|c|c|c|c|c|c|c|c|c|}
\hline & $\begin{array}{c}\text { Project: Second Gas Station CADD } \\
\text { Location: TTR }\end{array}$ & & & & & $\begin{array}{c}\text { Date: } \\
\text { Revision: }\end{array}$ & $\begin{array}{c}6 / 11 / 97 \\
\text { B }\end{array}$ & \\
\hline \multirow[t]{6}{*}{ Item } & Description & Quan. & Unit & Matl. & Labor & Subcontr. & Total & G\&A \\
\hline & Dump Trucks @ 15 & 2 & DAY & & & $\$ 9,375$ & $\$ 18.750$ & $\$ 2,438$ \\
\hline & Water Truck @ 1 & 2 & DAY & $\$ 133$ & & & $\$ 266$ & \\
\hline & Compactor@ 1 & 2 & DAY & $\$ 136$ & . & & $\$ 272$. & \\
\hline & Grader @ 1 & 2 & DAY & $\$ 136$ & & & $\$ 272$ & \\
\hline & Front End Loader @ 2 & 2 & DAY & $\$ 272$ & & & $\$ 544$ & \\
\hline \multicolumn{7}{|r|}{ SUBTOTAL } & $\$ 20,104$ & \\
\hline 2.4 & Subcontract G\&A & & & & & & $\$ 14,838$ & \\
\hline \multicolumn{7}{|c|}{ EXCAVATION \& DISPOSAL SUBTOTAL } & $\$ 212,537$ & \\
\hline 3.0 & FILLL(1960 CY) & & $\cdot$ & & & & & \\
\hline \multirow[t]{3}{*}{3.1} & MOBILIZATION & & & & & & & \\
\hline & Compactor@1 & 2 & DAY & $\$ 136$ & & & $\$ 272$ & \\
\hline & Grader@ @ 1 & 2 & DAY & $\$ 136$ & & & $\$ 272$ & \\
\hline \multicolumn{7}{|r|}{ SUBTOTAL } & $\$ 544$ & \\
\hline . & ALL OTHER EQUIP MOB/DEMOB IN 2.0 & & & & & & & \\
\hline \multirow[t]{10}{*}{3.2} & EXCAVATION/TRANSPORT/FILL & & & & & & & \\
\hline & $\begin{array}{l}\text { Dump Trucks @ } 15(8 \mathrm{Hr} \text { day plus per diem } \\
\$ 625 / \text { day/truck) }\end{array}$ & 3 & DAY & & & $\$ 9,375$ & $\$ 28,125$ & $\$ 3,656$ \\
\hline & WaterTruck@1 & 3 & DAY & $\$ 133$ & & & $\$ 399$ & \\
\hline & Front End Loader @ 2 & 3 & DAY & $\$ 272$ & & & $\$ 816$ & \\
\hline & Compactor@ 1 & 3 & DAY & $\$ 136$ & & & $\$ 408$ & \\
\hline & Grader@1 & 3 & DAY & $\$ 136$ & & & $\$ 408$ & \\
\hline & Superintendent @ 1 & 3 & DAY & & $\$ 990$ & & $\$ 2,970$ & \\
\hline & Equipment Operator @ 4 & 3 & DAY & & $\begin{array}{r}\$ 2,88 \\
0\end{array}$ & & $\$ 8,640$ & \\
\hline & Driver @ 1 for Water Truck & 3 & DAY & & $\$ 720$ & & $\$ 2,160$ & \\
\hline & TTR Per Diem @ 6 x \$36/day & 3 & DAY & $\$ 216$ & & & $\$ 648$ & \\
\hline \multicolumn{7}{|r|}{ SUBTOTAL } & $\$ 44,574$ & \\
\hline \multirow[t]{3}{*}{3.3} & DEMOBILIZATION & & & & & & & \\
\hline & Compactor @ 1 & 2 & DAY & $\$ 136$ & & & $\$ 272$ & \\
\hline & Grader @ 1 & 2 & DAY & $\$ 136$ & & & $\$ 272$ & \\
\hline \multicolumn{7}{|r|}{ SUBTOTAL } & $\$ 544$ & \\
\hline 3.4 & Subcontract G\&A & & & & & & $\$ 3,656$ & \\
\hline
\end{tabular}


Table B-1

IT Corporation Estimate Sheet

(Sheet 3 of 4)

\begin{tabular}{|c|c|c|c|c|c|c|c|c|}
\hline & $\begin{array}{c}\text { Project: Second Gas Station CADD } \\
\text { Location: TTR }\end{array}$ & & & & & $\begin{array}{l}\text { Date: } \\
\text { Revision: }\end{array}$ & $\begin{array}{c}6 / 11 / 97 \\
\text { B }\end{array}$ & \\
\hline Item & Description & Quan. & Unit & Matt. & Labor & Subcontr. & Total & G\&A \\
\hline \multicolumn{7}{|c|}{ FILL SUBTOTAL } & $\$ 49,318$ & \\
\hline 4.0 & ASPHALT (185 SY) & & & & & & & \\
\hline \multirow[t]{3}{*}{4.1} & Mobilization (Means crew B-37) & 2 & DAY & & & $\$ 1,750$ & $\$ 3,500$ & $\$ 455$ \\
\hline & 4" Asphalt replacement & 185 & SY & & & $\$ 33$ & $\$ 6.105$ & $\$ 794$ \\
\hline & Demobilization (Means crew B-37) & 2 & DAY & & & $\$ 1,750$ & $\$ 3,500$ & $\$ 455$ \\
\hline \multicolumn{7}{|r|}{ SUBTOTAL } & $\$ 13,105$ & \\
\hline 4.2 & Subcontract G\&A & & & & & & $\$ 1,704$ & \\
\hline \multicolumn{7}{|c|}{ ASPHALT TOTAL. } & $\$ 14,809$ & \\
\hline 5.0 & IN-SITU BIOREMEDIATION & & & & & & & \\
\hline 5.1 & MOBILIZATION/DEMOBILIZATION & 1 & LS & & & $\$ 5,000$ & $\$ 5,000$ & $\$ 650$ \\
\hline \multirow[t]{9}{*}{5.2} & INSTALL 2-4" DIA WELLS & & & & & & & \\
\hline & Drilling $40^{\prime}$ each & 80 & L.F. & & & $\$ 35$ & $\$ 2,800$ & $\$ 364$ \\
\hline & Well construction & 80 & L.F. & & & $\$ 12$ & $\$ 960$ & $\$ 125$ \\
\hline & 4" PVC casing & 60 & L.F. & & & $\$ 10$ & $\$ 600$ & $\$ 78$ \\
\hline & 4" PVC screen & 20 & L.F. & & & $\$ 13$ & $\$ 260$ & $\$ 34$ \\
\hline & Well abandonment & 80 & L.F. & & & $\$ 4$ & $\$ 320$ & $\$ 42$ \\
\hline & Well protection & 2 & EA & & & $\$ 350$ & $\$ 700$ & $\$ 91$ \\
\hline & 40 mil plastic liner & 2 & EA & $\$ 100$ & & & $\$ 200$ & $\$ 26$ \\
\hline & TTR Per Diem @ 4 Men & 5 & DAY & $\$ 144$ & & & $\$ 720$ & $\$ 94$ \\
\hline \multicolumn{7}{|c|}{ WELL INSTALLATION TOTAL } & $\$ 11,560$ & \\
\hline \multirow[t]{5}{*}{5.3} & CAPITAL EQUIPMENT & & & & & & & \\
\hline & Air Injector System & 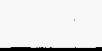 & & & & & & \\
\hline & 50 CFM Compressor & 1 & EA & $\begin{array}{r}\$ 8,50 \\
0\end{array}$ & & & $\$ 8,500$ & $\$ 1,105$ \\
\hline & Single stage Regulator & 1 & EA & $\$ 400$ & & & $\$ 400$ & $\$ 52$ \\
\hline & Regulator & 1 & EA & $\$ 460$ & & & $\$ 460$ & $\$ 60$ \\
\hline \multicolumn{7}{|c|}{ CAPITAL EQUIPMENT SUBTOTAL } & $\$ 9,360$ & \\
\hline 5.4 & AMMONIA & 3 & month & $\$ 200$ & & & $\$ 600$ & $\$ 78$ \\
\hline 5.5 & $\begin{array}{l}\text { ELECTRICITY } 15 \text { HP motor .05/KWH } \\
\text { (\$14/day) }\end{array}$ & 90 & DAY & & & $\$ 14$ & $\$ 1,260$ & \\
\hline
\end{tabular}


Table B-1

IT Corporation Estimate Sheet

(Sheet 4 of 4)

\begin{tabular}{|c|c|c|c|c|c|c|c|c|}
\hline & $\begin{array}{c}\text { Project: Second Gas Station CADD } \\
\text { Location: TTR }\end{array}$ & & & & & $\begin{array}{c}\text { Date: } \\
\text { Revision: }\end{array}$ & $\begin{array}{c}6 / 11 / 97 \\
\text { B }\end{array}$ & \\
\hline Item & Description & Quan. & Unit & Matl. & Labor & Subcontr. & Total & G\&A \\
\hline \multirow[t]{5}{*}{5.6} & $\begin{array}{l}\text { WELL SAMPLING (performed } 1 \text { per month for } \\
17 \text { months) }\end{array}$ & & & & & & & \\
\hline & 1- tech @ 17 days ( $\$ 320 /$ Day) & 17 & DAY. & & $\$ 320$ & & $\$ 5,440$ & \\
\hline & TTR Per Diem @ 1 Man & 17 & DAY & & & $\$ 36$ & $\$ 612$ & \\
\hline & Confirmation Samples & 1 & EA & & & $\$ 1,000$ & $\$ 1,000$ & \\
\hline & Report & 8 & $\mathrm{hr}$ & & $\$ 70$ & & $\$ 560$ & \\
\hline \multicolumn{7}{|c|}{ WELL SAMPLING SUBTOTAL } & $\$ 7,612$ & \\
\hline \multirow[t]{7}{*}{5.7} & $\begin{array}{l}\text { SOIL TESTING } 2 \text { Samples from each well, } \\
4 \text { total }\end{array}$ & & & & & & & \\
\hline & Soil Moisture & 4 & EA & & & $\$ 16$ & $\$ 64$ & $\$ 8$ \\
\hline & Phosphate & 4 & EA & & & $\$ 25$ & $\$ 100$ & $\$ 13$ \\
\hline & Ammonia & 4 & EA & & & $\$ 25$ & $\$ 100$ & $\$ 13$ \\
\hline & $\mathrm{PH}$ & 4 & EA & & & $\$ 15$ & $\$ 60$ & $\$ 8$ \\
\hline & Microbial Env. Column Study & 4 & EA & & & $\$ 2,000$ & $\$ 8,000$ & $\$ 1,040$ \\
\hline & Lime requirements & 4 & EA & & & $\$ 50$ & $\$ 200$ & $\$ 26$ \\
\hline \multicolumn{7}{|c|}{ SOIL TESTING SUBTOTAL } & $\$ 8,524$ & \\
\hline \multirow[t]{2}{*}{5.8} & SUBCONTRACT G\&A & & & & & & $\$ 3,906$ & \\
\hline & \multicolumn{6}{|c|}{ IN-SITU BIOREMEDIATION TOTAL } & $\$ 42,822$ & \\
\hline
\end{tabular}




\section{Distribution List}

Paul Liebendorfer

Bureau of Federal Facilities

Division of Environmental Protection

333 W. Nye Lane

Carson City, NV 89710

Donald A. Garrepy

Bureau of Federal Facilities

Division of Environmental Protection

555 E. Washington, Suite 4300

Las Vegas, NV 89101

Sabrina Bonnell

Environmental Restoration Division

DOE/Nevada Operations Office

P.O. Box 98518, M/S 505

Las Vegas, NV 89193-8518

DOE Public Reading Room

P.O. Box 98521, M/S NLV040

Las Vegas, NV 89193-8521

Rosa Silver

IT Corporation, M/S 439

P.O. Box 93838

Las Vegas, NV 89193

U.S. Department of Energy

Office of Scientific and Technical Information

175 Oak Ridge Turnpike

P.O. Box 62

Oak Ridge, TN 37831
2 (Controlled)

1 (Controlled)

1 (Controlled)

1 (Controlled)

2 (Controlled)

2 (Uncontrolled) 
DOE/Nevada Operations Office

1 (Uncontrolled)

Technical Information Resource Center

P.O. Box 98518, M/S 505

Las Vegas, NV 89193-8518

Janet Appenzeller-Wing

1 (Uncontrolled)

Environmental Restoration Division

DOE/Nevada Operations Office

P.O. Box 98518, M/S 505

Las Vegas, NV 89193-8518

Kevin Cabble

1 (Uncontrolled)

Environmental Restoration Division

DOE/Nevada Operations Office

P.O. Box 98518, M/S 505

Las Vegas, NV 89193-8518

Dave Madsen

1 (Uncontrolled)

Bechtel Nevada

P.O. Box 98521, M/S NTS306

Las Vegas, NV 89193-8521

Steve Nacht

1 (Uncontrolled)

Bechtel Nevada

P.O. Box 98521, M/S NTS306

Las Vegas, NV 89193-8521

Vern Gabbard

1 (Uncontrolled)

Sandia National Laboratories

P.O. Box 871

Tonopah, NV 89049

Ken Beach

IT Corporation, M/S 439

1 (Uncontrolled)

P.O. Box 93838

Las Vegas, NV 89193

Mary E. Todd

SAIC, M/S 439

1 (Uncontrolled)

P.O. Box 93838

Las Vegas, NV 89193 
IT Corporation Central Files

IT Corporation, M/S 439

P.O. Box 93838

Las Vegas, NV 89193

DOE Public Reading Room

P.O. Box 98521, M/S NLV040

Las Vegas, NV 89193-8521
1 (Uncontrolled)

1 (Uncontrolled) 